

\section{MARINE BIOLOGICAL LABORATORY.}

Received JuIJ, 1935

Accession No. 44420

Given by Dr. H. R. Fi Place, "oods itole oce notraphic

** No book or pamphlet is to be removed from the Laboratory without the permission of the Trustees. 








\section{JOURNAL OF \\ JOHN JAMES AUDUBON \\ I $820-1821$}





\title{
FOURNAL $\mathrm{OF}$ \\ JOHN JAMES AUDUBON \\ MADE DURING HIS TRIP TO \\ NEW ORLEANS IN I820-I82I
}

\author{
EDITED BY \\ HOWARD CORNING
}

FOREWORD BY

RUTHVEN DEANE

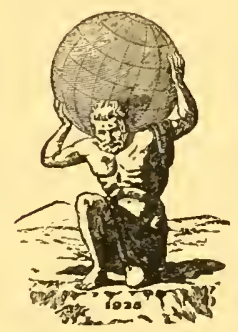

C A M B R I D G E

THE BUSINESS HISTORICAL SOCIETY

MCMXXIX 
COPYRIGHT, I 929， BY

THE CLUB OF ODD VOLUMES 


\section{INTRODUCTION}

The Journals of Audubon which are printed in these two volumes are, so far as is known, the only Diaries of his in existence. Some years ago the family destroyed all the manuscripts which were in their possession. These two Diaries cover two different periods of Audubon's life, twenty years apart. They were given to the Museum of Comparative Zoölogy of Harvard University, together with seven books of account, through the generosity of Col. Fohn E. Thayer, of Lancaster, Massachusetts, in I9I3. The contents have never been published, though some extracts from the I820 Journal were published in Volume 21 of the "Auk," the magazine of the American Ornithological Union. The extracts themselves, however, are not an exact copy of the original Journal.

The first Journal covers the period from the twelfth of October, I820, to the thirty-first of December, I821, and reports Audubon's journey down the Ohio and Mississippi rivers, and part of his residence in New Orleans. It is a very human document, written at odd moments and under difficult conditions, and conveys, as nothing else can, an understanding of the man.

The second Fournal covers the period from fuly 13,1840 , to October II, I843, twenty odd years later than the first. At this time his reputation was established, and he journeyed over the country from Newburyport, Massachusetts to Richmond, Virginia, and also in Canada, soliciting subscriptions for the octavo edition of "Birds of America," and commenting on the people whom he met. 
The first fournal is published word for word, with the original spelling, in an endeavor to make it possible for the reader to enjoy it as if the original manuscript was in his hands. In the second fournal a few corrections have been made of obvious errors in writing.

Words enclosed in brackets were crossed out by Audubon and other words substituted. In certain cases, where the words crossed out could not be deciphered, the bracket is left blank. In no case have attempts been made to interpret an undecipherable word. Words and letters in italics indicate that they were underlined in the manuscript.

The portrait of Audubon was painted by Audubon himself in I824, and is now the property of Dr. David Gambel Murrell of Paducah, Kentucky. A very poor reproduction of this was published in the "Auk" in I886. I am indebted for a copy of this photograph to the generosity of Mr. Stanley C. Arthur, Director Division of Wild Life, Department of Conservation, State of Louisiana, who has for a long time been making a study of Audubon's life while Audubon was in and about New Orleans.

I wish to acknowledge my indebtedness to Dr. Thomas Barbour, Director of the Museum of Comparative Zoölogy of Harvard University, for permission to publish the Diaries; to Mr. Ruthven Deane of Chicago, Ill., and to Prof. Francis H. Herrick, of Western Reserve University, Cleveland, Ohio, for advice and criticism; and to Dr. Glover M. Allen, of the Museum, for suggestions and help in reading the text. I wish also to acknowledge the interest of Dr. Mary Linehan MacKinnon, whose assistance has materially lightened the preparation of the text.

HOWARD CORNING

Cambridge

Massachusetts 


\section{FOREWORD}

T $\mathrm{HE}$ seemingly exhaustive histories on the life and works of John James Audubon which have been written by his granddaughter, Maria R. Audubon and Prof. Francis H. Herrick, would indicate that but little more could be added, yet hardly a year goes by but more hitherto unpublished letters and facts of unusual interest are brought to light.

This original Fournal, kept by Audubon on that famous journey down the Ohio and Mississippi rivers in I820-2I, and his life in New Orleans and the surrounding country, shows the indefatigable ardor and untiring effort to acquaint himself with a new territory, and the discovery of new species of birds for his forthcoming work.

There probably never was a naturalist who, in his early career, suffered more privations, and outlived so many discouraging years, finally to receive his great reward.

Some years ago Col. Fohn E. Thayer acquired this Journal from a member of the Audubon family, and generously deposited it with the Harvard Museum of Comparative Zoology, where it would be safe for all time. All lovers of Auduboniana will now be grateful for the opportunity to read this original Journal, published verbatim et litteratim, of this great painter-naturalist.

Scarborough Beach

RUTHVEN DEANE

Maine 



\section{JOURNAL OF \\ JOHN JAMES AUDUBON \\ I 820-I 82 I}





\section{AUDUBON FOURNAL

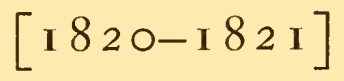

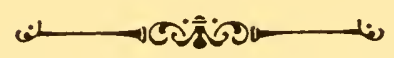

Thursday-Ohio River Oct-i 2 th i 820.

I left Cincinnati [today at] this afternoon at half past 4 o'clock, on Board of Mr. Jacob Aumack's flat Boat-bound to New Orleans-the feeling of a Husband and a Father, were My Lot when I kissed My Beloved Wife \& Children with an expectation of being absent for Seven Months-

I took with me Joseph Mason a Young Man of about i 8 years of age of good familly and naturally an aimiable Youth, he is intended to be a Companion, \& a Friend; and if God will grant us a safe return to our famillies our Wishes will be [most Likely] congenial to our present feelings Leaving Home with a Determined Mind to fulfill our Object =

Without any Money My Talents are to be My Support and My enthusiasm my Guide in My Dificulties, the whole of which I am ready to exert to [meet] keep, and to surmount. 


\section{A UDUBON JOURNAL}

The Watter is Low, although a Little froth, sailed the River a few days since, about $4 \frac{1}{8}$ feet. We only floated I4 Miles by the Break of the 1 3 th of Octre the Day was fine, [and] I prayed for the health of My familly - prepared Our Guns and went on shore [on the] in Kentucky [Side] - Cap ${ }^{\mathrm{e}}$ Sam $^{1}$ Cummings who left Cincinnati with an Intention of Noting the Channels of this River and the Mississipi accompanied us-We shot thirty Partridges-I Wood Cock-27 Grey Squirrelsa Barn Owl--a Young Turkey Buzzard and an Autumnal Warbler as Mr. A. Willson as being pleased to denominate the Young of the Yellow Rump Warbler -this was a Young Male in beautifull plumage for the season and I Drew it-as I feel perfectly Convinced that Mr. Willson has made an Error in presenting this Bird as a New Specie I shall only recommend You to Examine attentively My Drawing of Each and his Description-its Stomach was filled with the remaines of Small Winged Insects and 3 Seeds of Some Berries, the names of which I could not determine-

Early in the morning the wind rose and we came to on the Ohio side by $\mathrm{G}^{1} \mathrm{~W}^{\mathrm{m}}$ Harrisons' Plantationand remained untill nine o'clock $P M$ -

I saw several flocks of Ducks in the morning before we had cleaned our Guns--hundreds of Meadow Lark Alanda Magna seen travelling Southwest- 


\section{AUDUBON JOURNAL}

[the Night became] the Wind Rose and brought us to shore, it raind and blowed Violantly untill the Next Day-

\section{Saturday Oct $14^{\text {th }}$ I 820}

After an early Breakfast We took to the Woods I say We because Joseph Mason, Cape Cummings \& myself I believe are allways [-] together-

I shot a Fish Hawk Falco Aliaetos at the mouth of the Big Miami River a handsom Male in good Plumage. he was wingd only and in attempting to Seize Joseph's hand, he ran one of his Claws through the Lower Mandille of his Bill and exibited a very Ludicrous object - these Birds walk with great dificulty and Like all of the Falco and Strix Young throw themselves on their backs to defend themselves-

We returnd to our Boat with a Wild Turkey 7 Partriges a Tall Tale Godwit and a Hermit Thrush which was too much torn to make a drawing of it this was the first time I had met with this Bird and felt particularly Mortified at the Situation-

We passd the Small Towns of [Madi] Laurenceburgh-in Indiana-Petersbugh in $\mathrm{K}^{\mathrm{y}}$.- , We Walked in the afternoon to Bellevue the former residence of a Far Famed Lady of our acquaintance $\mathrm{M}^{\text {rs }}$ Bruce; Saw Thomas Newell and old Cape Green-if My Eyes did not err I saw my suspicions of her conduct that Evening Justified. We Killed 4 Small Grebes at one Shot from a Flock of about 30 We approached them with 


\section{A UDUBON JOURNAL}

ease to within about 40 yards, they were chassing each other and quite Merry when the Destructive fire through the Whole in consternation. the Many Wounded escaped by Diving the rest flew off-this is the second time I have seen this Kind, and they must be extremely rare [Bird] in this part of America-

About Three Miles above Bellevue in Kentucky we walked through a Fissure of Rocks really romantic the Passage in [that] form of a half Moon is about 6 feet Wide, the rocks are composed of Large Round pebles cimented with Coarse Sand about I oo feet High on one Side and Sixty on the other-I made a Sketch of it for [my] your future Pleasure-We walked this day about 40 miles Saw one Deer crossing the River

\section{Sunday Oct. 15, I $820-$}

there was this morning as heavy a white frost as I Ever Saw, the Wind blew cold and heavy from the North Shott 2 Tell Tale Godwits-and chased a Deer in the River for some considerable time, but a Canoe with Two Indianna Men had the advantage of us and caught it as I rose to shoot it - the Wind being fair We floated tolerably well, killed 5 Teal One Blue Wingd Teal, [a young Malard] 2 Doves 3 Partriges and fortunately another Hermit Thrush Turdus Solitarius -We met and went on Board the Steam Boat Velocipede Saw Col. Oldham, Mr. Bruce, Mr. Talcut \& Lady [on Board] Passengers besides a Consider Num- 
ber of Strangers, Opend a Letter directed to Your Mother by Your Uncle Wam B-Mr [-] Aumack Killed a Young Malard Duck - the Contents of the [-] Gizard of one of the 4 Grebes I open was Nothing else than a solid mass of fine hair apparently belonging to some very Small quadrupeds-(feathers)

Saw a Chimney Swallow; the Number of Ducks Increasing-and an Appearance of a Cold NightsKilled a Great Carolina Wren the Grebes were cooked and eat but extremely Fishy rancid and fat-

at io 'oclock We were roused from sound sleep by the Boats having ran on Rocks-the hands had to go in the Watter to take them off, it was cold and Windy-

\section{Monday Oct i 6 th i 820}

the frost much as yesterday; Turkey, being heard close by we took a walk after them unsuccessfully, they answered to my calls but kept off-

I did not feel well; took some Medicine and Drew the Hermit Thrush Turdus Solitarius that I killed yesterday-this Bird can easily be known from the Turdus Auracapillus being about $\frac{1}{3}$ Larger, and from the Tawny Thrush, by Looking at the inner part of its Wings which exhibit a handsome light Band of Buffits stomach contained the remains of insects and the Seed of the Winter Grape-was very fat and [and] delicate eating - these Birds are scarce and not generally known their note a plaintive soft one-Seldom 


\section{AUDUBON JOURNAL}

more than 2 are seen together-Some of the Country we saw [to] is extremely high, hilly and broken-saw a wood grouse-many ducks Several Northern Divers or Loons-Some Cormorants, Many Crows-Several flocks of Cow Buntings moving Southward-Killed two Partriges and One Turkey-

the Boats ran ashore sandbar at Seven o'clock, with great Exercising one was brought off it was the one I was living in the other stayed fast all night, the hands suffered much from the cold-

\section{Tuesday Oct $7^{\text {th }}$ I 820}

The weather disagreably Cold, but Glear, the other Boat still fast We went early on Shore,-in Kentucky -a Long Walk through the woods was fruitless, I saw 4 Ravens-Many Winter Hawks-some Red breasted Thrushes or Robins-the Wood full of Grey \& Black Squirrels returned to the Boats the other having joined us with Two Turkeys \& One Wood Grouse or Pheasant-

The Turkeys extremely plenty and Crossing the River hourly from the North Side, great Number destroyed [there] falling in the Stream from want of strength - the Partrige when Crossing also, and in fact, all the Game that Cannot propery be called Migratorius $=$

Saw a Great Number of Chimney Swallows going Southwest-this Bird travells much more advan- 


\section{AUDUBON JOURNAL}

tageously than most all others being able to feed without halting-Killed a fine American Buzard Falco Leverianus he was feeding on a Grey Squirel on a stump tree, he fell to the ground and Raised again without loosing his praise-his stomack was filled with that Last Prey-a Large Turkey Cock was stolen from us by some travellers-killed today I7. partridges-One wood grouse 4 Turkeys I Killed 2 at one shot-One Hare-One Robin and the American Buzzard-We put some fish Lines out having Landed for the Night all hands being very much fatigued-

Could My Wishes be fulfilled I would have [the] you well fed on that game as the rich calls it richestthe thermometre down at $36-$

\section{Wednesday, Oct. i 8th, i 820}

Jacob Aumack went hunting with us saw some fine Turkeys, Killed a Common Crow Corvus [-] Americanus which I Drew; many Robins in the woods and thousand of Snow Buntings Emberiza Nivalis-several Rose Breasted Gross Beaks-We killed 2 Pheasants, I 5 Partridges-I Teal, I T. T. Godwit-i Small Grebe all of these I have seen precisely alike in all parts-and one Barred Owl that is undoutedly the most plentifull of his Genus-I felt poorly all day and Drawing in a Boat were a man cannot stand erect gave me a Violent headache-The Watter raising a little gave me some Hopes of reaching Louisville before Sunday-anxious 


\section{A UDUBON JOURNAL}

to know my Fate-I am confortably situated and would be sorry to be obliged to part with them-the Weather Milde \& Cloudy-Caught No Fish Last night-

\section{Thursday Oct. ${ }^{\mathrm{r}}$ - I 9 th $\mathrm{I} 820$}

Cape Cummings $\mathrm{M}^{\mathrm{r}}$ Aumack and Joseph after a Long Walk return to Dinner with only 7 Partridges and I Pheasant-Mr Shaw Shot I Pheasant-I finished my Drawing of the Common Crow and after Dinner Went a Shore with the Company-saw Many Cedar Birds killed a Young Blackburnian Warblera Young Carolina Cuckow so much reduce by the Hard Weather that he could scarcely fly-killed 5 pheasants 14 Partridges I Squirel and 3 Turkeys, Shot at once by Joseph who was not a little proud when he heard 3 Chears given him from the Boats this was his first essay on Turkeys-

[in the] While absent the boats having put too to make Sweeps. a flock of Turkeys came among ${ }^{t}$ them and in tring to kill some with Aumack's pistols one was bustted and the other wounded Joseph's Scull pretty severely-saw an astonishing number of Gray Squirels-the Country being extremely hilly opposite Wells Point the hunting Was Laborious and fatiguing.

The Stomack of the Cuckoo Contained 2 entire Grass Hopers one Large Green Kid diddid and the remainder of remains of Diferents colopterous Insects. 


\section{Wednesday Novembri ${ }^{r}$ ist 1820}

Weather drizly and windy Landed a few hundred yards below Evansville in Indianna on a/c of $\mathrm{M}^{\mathrm{r}}$ Aumack Who had some money to Collect-he brought on Board only a french Double Barrel Gun and a Gold Watch the man made for Sale-I Wrote to my Beloved Wife E $M r H$. W. Wheeler Saw Large flocks of Snow Geese but only one in perfect Plumage.

Not so stupid as mentioned in Linne. Left Evansville at 2 o'clock P.M.-Capt Cummings \& Joseph parted in the Skiff for Henderson to Get Dash a slut I had Left in the Charge of Mr Brigs-about 3 Miles down We Saw 3 of these Birds that I have considered as being the Brown Pelican they made a noise somewhat like a raven-they alighted on a Red Maple Tree-after many [fruitless] hard trials:-We landed below them and Went a Shore with great expectation of Procuring one- $\mathrm{M}^{\mathrm{r}}$ Aumack drew near them but Missed 2 that Were together and that I expected and hoped to see fall-the wind raising it was Concluded We Should remain-rather sorry that the Cap ${ }^{\mathrm{e}}$ \& Joseph were absent-as we had expected to go Within 2 Miles of Henderson \& meet them [them] on their return-

The people at Evansville very Sickly, could not see $\mathrm{Mr}^{\mathrm{r}} \mathrm{D}^{\mathrm{d}}$ Negley as it was my wish, he being at his House 4 Miles up Pigeon Creek- 


\section{A UDUBON JOURNAL}

Extremely tired of my Indolent Way of Living not having procured any thing to draw since Louisville-

\section{Thursday November 2nd, i82o}

Cape Cummings Joseph \& Dash arrived at one o'clock this morning having a severe rowing match of it We started about 5 and floated down slowly within 2 miles of Henderson when We experienced quite a Gale and Put to on the Indianna Shore opposite Henderson-The Wind Blew so violently that I could only make a very rough Drawing of that Place-I can scarcely Conceive that I staid there 8 Years and Passed them Comfortably for it undoutedly is one the poorest Spots in the Western Country according to My present opinion $=$

Saw some Large Sea Gulls-a: Larus argentatus Some Geese, Ducks, \&c. So Warm to night that Bats are flying near the Boats-extremely anxious to be doing something in the Drawing Way-

a: they are Pale blue above, Tail \& Belly White-a few of the outer Primaries Black and about the size of a Raven-

\section{Friday Novembr 3 rd, I 820}

We left our harbour at day Break and passed Henderson about sun raise, I Looked on the Mill perhaps for the Last Time, and with thoughts that made my Blood almost Cold bid it an eternal farewell- 
Here one of the hands left us a Poor Sickly Devil who had been acting as Cook, called Luke a Shoe Maker of Cincinnati-

The Indian Summer that extraordinary Phenomenon of North America, is now in all its Splendor, the Blood Red Raising Sun-and the Constant Smoky atmosphere, is undoutedly not easily to be accounted forit has been often supposed that the Indians, firing the Prairies of the West were the Cause, but since We have Left C. the Eastwardly Winds have prevailed without diminishing in any degree the Smoke-it is extremely bad to Most Eyes and particularly so to Mine-

Cape Cummings, Mr Shaw \& Joseph took a Long Walk [for] but saw nothing, killed 4 Squirels-one Butcher Bird, and a Swamp Blackbird-Large flocks of them seen travelling Southwest-I shot a Turkey Buzard, Vulture Aura about I 20 yards off with a ballSaw When We Landed at the foot of Diamond Island a fine Snow Goose [but] a Young One-Saw several N. Divers, Some Geese, a few Sand Hill Cranes-\& some Ducks-

\section{Saturday Novembr $4^{\text {th }}$, I820}

Landed Last evening opposite the Middle of Diamond Island lately the property of Walter Alves Deceased of Henderson-about 9 o'clock the Wind Rose \& Blowed a tremendous Gale which continued 


\section{A UDUBON JOURNAL}

all Night, fortunately for us We Were under the Lee of the Land-

This Morning the Wind had abated alitle, but We could not go, the River making immediatly below us a Turn Southwest ${ }^{\mathrm{d}}-5$ of us took guns and Went to the Island, We Walked almost all over it-Saw great many Turkeys-and Many Dears-I killed a Large Buck that died in the Cane, and Lost it-We Brought Nothing on Board, if 2 of us only had been there, probably We could have Made a good hunt-I Shot a Winter Wren but cut it so much that it could not be drawn [it]-

Returned to our Boats about 5 o'clock the Wind still Blowing, but rounding to the Northwest and Weather very Cold.

Watter falling-

I Remarked this morning that the Turkey Buzzards that had roosted over a dead Hog Last Night, Took a Long flight eastwardly this Morning as if to excite their appetite and returned to Consume their filthy Meal about 2 o'clock the number considerably Increased-While sailing high several Hawks for the Sake of amusement Chased them and sailed Many of them almost to the ground-

My Slut Dash apparently good for nothing for the want of Employment-

Now \& Then We see a Blue Crane-Saw Many Wood Groos on the Island 


\section{Sunday November 5 th, 1820}

The Weather fair this morning, the Thermoter down at 30 -the sun rose beautifull and reflected through the Trees on the Placid Stream much like a Column of Lively fire-the frost was heavy on the decks and when the Sun Shun of it it Looked beautifull beyond expression-

We floated tolerably well the river being here contracted by Large Sand Barrs-

Gayly we were overtaken by a Skiff containing a Couple of Gentill Young Men, Bound to New Orleans they had Matrasses, Trunks, a Gun \& Provisions-

Saw about the same time a fine Brown EagleShot at it without effect-

Many Dears where Merely Gamboling on the Sand Barrs and [much] excited us [to]

We passed Mount Vernon a Small Village in Indianna about one mile above the upper end of Slim Island$M^{r}$ Shaw \& Cape Cummings went to the Island but returned without any thing-this part of the River rather Dificult-

We Landed about 3 Miles above the Mouth of High Land Creek in the Mississipi Bend-

Saw Many Geese, some Sand Hill Cranes-a few Loons some Red Breasted Thrushes, many Sparrows \& parokets.

Killed only one Winter Hawk, \& Shot at one Wood Cock. 
as I promised You a Picture of the Caracters We have on Board of Both Boats I will attempt to Copy them, [Was my Talent in writting anything] Could my Pen Act as a Black Chalk by the help of my fingers you might rely on the Exibition of the figures-Yet I undertake it with pleasure, knowing how sweet this May be to you \& Myself some Years hence, while sitting together by the fireside Looking at Your Dear Mother reading to us-

being on Board of Boats Much in the situation of Passengers I am of Course Bound to give the preference to those who are termed Capitains and $\mathrm{Mr}$ Aumack is the First that I will bring to your attention-

You have seen him and of Course I have not much to say the acquaintance of Man When unconnected by Interest is plain [and] easily understood \& Seldom Deviates.-

he is a good Strong, Young Man, Generously Inclined rather Timorous on the River, Yet Brave and accustomed to hardships-he Commands the Boat where I am-

$\mathrm{M}^{\mathrm{r}}$ Loveless is a good Natured Natured, rough fellow brought up to Work without pride, rather anxious to Make Money-Playfull \& fond of Jokes \& Women-

$\mathrm{M}^{\mathrm{r}}$ Shaw the owner of Most of the Cargo puts me in mind of some Jews, who are all Intent on their Interest \& Wellfare; of a keen Visage \& Manners; 
a Bostonian-Weak of Constitution but strong of Stomack-Would Live Well if at any one else' Expense. =

The Crew is Composed as follows

Ned Kelly a Wag of 21. Stout Well Made, handsome if Clean, possessed of Much Low Wit, produces Mirth to the Whole even in his Braggardism-Sings, dances and fiels always happy-he is Baltimorian-

2 Men from Pennsylvania although not brothers, are possessed of a great sameness of Caracters-these are Anthony P. Bodley \& Henry Sesler-they Work Work Well, talk but litle and are Carpenters by Trade.

The Last is Much Like the Last of every thing, the Worst Part-Joseph Seeg, Lazy, fond of Grog, says nothing because it cannot help himself, sleeps Sound, for he burns all his Cloths, while in the ashes

Cape Cummings Joseph \& Myself form the Rear at Times and at Times the Van-You have seen the Life and there Likeness could not give you a better Impression than that you have formed-We agree Well, and are Likely to agree Still-

\section{Monday, Novembr 6th i 820}

The thermometer this morning was down at 28 and it felt very disagreable-Took to the Shore and walked 9 miles to the Mouth of the Wabash, but saw nothing to Shoot at-about one Mile below that the Wind 


\section{A UDUBON JOURNAL}

springing ahead Brought us to on the Illinois Shore and 5 Guns went hunting, I shot 6 Dear!-

the people here have a dreadfull sickly aspect and their Deportment not the Most Inticing-

the Caves plenty-

Our Boats started about One Hour before sun down, \& Cape Cummings having extended his hunt up the Wabash had a Long Walk for nothing-

We landed for the Night about 6 miles above Shawaney Town on the Kentucky Shore-

Weather appearance of rain, and blowing, Much Warmer-

Saw Some Robins, a few Blue Jays, a few Blue Birds, Geese, S. H. Cranes, Ducks-Buzzards \& the [general] usual number of W. Peckers common at this season-

\section{Tuesday Novembr 7 th 1820}

Weather at 50 this morning, rainy \& Desagreable, Landed at Shawaney Town where we staid six hours -I staid snugg on Board Mr Aumack having naild up the only accessible hole to our Boat.-

I Wrote to My Wife \& Directed it to $\mathrm{M}^{r}$ WheelerWe left Shawaney town at half $5 \&$ went only to the Lower end of it, the Wind raising again with an appearance of a Very Boisterous Night-

Jacob Aumack killed a Rusty Grakle a beautifull Male and as these Birds are scarce I intend Drawing 
A UDUBON JOURNAL

it tomorrow $=$ it is but seldom that Many of these Birds are seen together, they Walk with great Statliness and Elegance, are swifter of flight than the Swamp Blackbirds.

I felt very anxious during all the time of our stay to be off from this Place.

This Evening Ned Kelly \& his Companion Joc Seeg having Drank rather freely of Grog, they had a Litle Scrape at the Expense of Mr Seeg's Eyes \& Nose-

The People of Shawney Complaining of Sickness, the place improved but Litle

\section{Wednesday Novemb ${ }^{\mathrm{r}}$ 8th, I 820}

the Weather Calm \& beautifull this Morning [and] We started with a good prospect and our Landing within Two Miles of the famous Rock in Cave to night prove it-

I Drew this Morning My Rusty Grakle, Gracula Ferruginea, and made a handsome piece of it.

Cape Cummings hunted all day but saw nothing - since 3 Days we have been particularly unfortunate in our Hunts.

Near our Landing Place We Went on Shore to procure some Venaison Hams-Mr Shaw bought $4 \mathrm{p}^{\mathrm{rs}}$ for $2 \$$ remarkably fine-the young man who sold them had Killed 3 Dear to day and had hung one Large Buck for his Dogs to feed on-

Killed to day One Grey Squirel \& 3 Tell Tale God- 


\section{A UDUBON JOURNAL}

wits these Birds Wade so deep that one would suppose they are swimming, fly a few Yards into Shallower Watter, holding their wings up untill perfectly satisfied of their being on the Bottom-then run about briskly \& ketch small fishes with great dexterity-

Saw one Sea Gull a Large one-a few Gold Finches Many Cardinals-some Divers-but neither Ducks or Geese-The Weather has become Cloudy \& raining by Intervalls is Now beautifull with an appearance of Frost

about Two hours before sun sett a Barred Owl teased by four Crows and Chased from the tree where he was Lit raised up in the manner of a Hawk in the air so high that We Lost Entire sight of him, he acted as if Lost-now \& then making very short Circles and flapping his Wings quickly, then zig zag lines-this was quite a new Sight and I expect take place but seldom-I felt anxious to see his Descent to the Earth but Could not-

The Trees here have Lost all their foliage, the Cane \& a few Green Briars is all that animate the Woodsthe Shores are thickly sett with Cotton Wood Trees.

\section{Thursday Novembr 9 th 1820}

The Wind blowed nearly all day a head, the Weather cold-Saw no Game although We Walked a great deal in the Woods the Country extremely poor here- 
We Landed at Sun Set at the Rockin Cave having Come only about 2 Miles-

I began My Sketch of it immediately, regretting that We had not reached this place Last Night.

We Purchased a Skiff from a flat Boat-Ducks \& Geese very numerous flying down the Stream-Shot 2 Ducks of the flocking Fowl Kind-\& 3 Squirelsthe Thermometer in the Watter at sun set was down to 27, appearance of a Very Cold Night-

a Man on the Shore told me that Last Winter he had Caught a Large Number of Malard Ducks with a Trap set with a figure of 4 \& shaped Like a Partridge trap

The Tell Tales we eat to Day were very fat but very fishy-I eat the purple Grakle it tasted well-

\section{Friday Novembr Ioth I 820}

as soon as Day Light permitted me this morning-I Took Joseph on Shore and Lighted a good fire-took also My Drawing Book etc with a Skiff-the Morning pleasant and the Thermometer raised to $50^{\circ}$ While I was taking My Sketch of the Rockin Cave Cape Cummings took a Good Walk through the Woods-at 9 My Drawing was compleat-this Cave is one of the Curiosities that attract the attention of allmost every Traveler on the Ohio and thousands of Names \& Dates ornament the sides \& Cealing-there is a small upper room dificult of access imediatly above \& 


\section{A U D UBON JOURNAL}

through the Cealing of the Ground floord one, Large enough to Contain 4 or 5 persons when sitted on their hams - this place is said to have been for Many Years the rendez Vous of a noted Robber of the name of Mason it is about 20 Miles below Shawaney town on the same side; had our Boats spent a Day there, I would have been pleased to take several Diferent Views of it - the Rocks are Blue Lime Stone containing in Many Parts Round Masses of a fine flinty appearance Darker than the main Body-

at Nine o'clock it became Cloudy \& Cold, We left for our Boats, but before We reached them, it snowed \& Hailed \& Wetted us Compitly-Our Boats had parted to Cross \& Run through the Walker's Barr and Hurricane Island-We Landed only about One Mile below the Latter, the rain Increasing and the Weather extremely Disagreable-Never have seen so much snow at this season in this Latitude-

Saw a fine Black Hawk Falco Niger-\& Black Gull, -Shot Two Ducks-

\section{Saturday Novembri i ith, I 820}

It rained hard during the whole of the Night and this day floated only about 7 Miles-

Saw a few Turkeys,--

A Flock of Carrion Crows made us go to the shore but they were so exceedingly shy that they would fly several hundred Yards off-while the Turkey Buzzards 
AUDUBON JOURNAL

that [when] accompanied them would suffer us to Walk under the trees on which they alighted-the Carrion Crows are very scarce in this Part of the Country and keep Generally Lower to the South-their flight is heavy and their appearance while on the Wing awkward

We Landed for the Night a Golconda a small Town of the Illinois-Titles disputed of course the place not Improving-Court was sitting-

\section{Sunday Novembr i 2 th 1820}

The Wind Blowed this Morning and We did Not Leave the Shore untill 9 o'clock-Wind fair-Weather raw \& Cloudy-Mr. Aumack Killed a Duck [Ruddy Duck] out of a Flock of 5 that proved to be a Nondescript-and also a Imber Diver - the Wind rendered our Cabin smoky I could Not begin to Draw untill after Dinner-I had the pleasure of Seing Two of the same Ducks Swimming Deep, with their Tail erect, and Diving for food-having never seen these Birds before, it was highly satisfactorily to $\mathrm{Me}$-Tomorrow I will give a thorough Description of it

The Imber Diver was Shot Dead and proved a beautifull specimen-of Cours I will give You a Drawing of it-for Some time before I procured one of them; they Were Called Northern Divers, the Moment I Saw this, the size and Coloring Made Me Sure of it being an Imber Diver- 


\section{A UDUBON JOURNAL}

Saw a Large flock of Turkeys fly across from an Island to the Main, killed None-

We are Landed about half a Mile above the Cumberland Island the weather not so cold as it feels the Thermometer at 38 -had some spits of snow in the forenoon-

Vast flocks of Ducks \& Geese flying Southwardly

\section{Monday Novembri $3^{\text {th }}$ i 820}

a Beautifull Morning enable ${ }^{d}$ me to go on with my Drawing very early - a Light frost embelished the raising of the Sun

We Landed at the Middle of Cumberland Island to dispatch a Skiff to take Soundings-

finished My Duck by Dinner Time and Was Lucky enough to kill another of the same kind, precisely a Like but rather Less in Size, it is with apparent Dificulty or a Sluggish disposition that these Birds rise out of the Watter \& yet will not dive at the flash of a Gun-while on the Wing are very Swift

this afternoon I Begun the Drawing of the Imber Diver had Two Long Chases after a Couple of others, that out Managed our Skill-they would Dive as if Going down the Stream and raised from One to Two hundred Yards above us-they frequently Dipp their Bill in the Watter, and I think have the power of judging in that Way if the place Contains Fish-One I shot 
at; dove \& raised again Imediatly as if to see Where I was or What Was the Matter-

I Saw Several of the Fin Tail Ducks, all acting the Same Way i.e. Swimming Deep \& the Tail ErectNo Doubt this appendage is very usefull to them when under the Watter-

Saw a Bear on a Sand Barr, had a great run after it-to no purpose-

Saw 2 of those Birds I take for Black PelicansMany Loose flocks of Blackbirds Ducks \& Geese-Mr Aumack saw an Eagle with a White head and Brown Body \& Tail, this Corroborates with the Idea of Willson of its being the same Bird with the Brown Eagle

Landed about the Middle of Tenessee Island Weather Much Milder-

Joseph Made a Faux Pas this day-the Whole of our Folks not in the best humour-Killed 7 Partridges I G. Squirel \& One Duck

\section{Tuesday Novembri $14^{\text {th }}$ I 820}

Drawing this Morning as soon as the Light would permit me-Started early-

Went out in the Skiff to try to Shoot the Largest White Crane, with Black tips, but he walk ${ }^{d}$ off from the Shore and I return ${ }^{d}$ knowing that it would be vain to attempt to follow him on a Large naked Sand Barrfelt great anxiety to procure such for he appeared Beautifull-- 
Saw several Eagles, Brown \& White headedAlthough I drew nearly the whole of this day I did finished My Imber Diver;

Cap ${ }^{\mathrm{e}}$ Cummings killed 26 Starlings, Sturnus Pradetorius all young-eat them at our Supper, good \& Delicate-I golden Plover \& Two Squirels-

Mr. Shaw killed an Owl that unfortunately he did not fetch; =We passed this Day Fort Massacre here the Ohio is Magnificent, the river about one \& $\frac{1}{4}$ mile Wide affords a view of 14 or 15 Miles, and this afternoon being Calm with one of those Whimsical sunsetts that only belong to America rendered the Scene extremely interesting.

We landed about One Mile below what is called the Little Chain an partial obstruction to the Navigation of this Queen of Rivers.--

Saw several Swans flying very high-Geese are in Constant View but have so far outwited us, these Birds are Wilder on the Rivers than when in the Ponds or small Lake that in Many places run Parralel with the Ohio at a Small distance in Land-

Cape C. Brought an Oppossum, Dash after having broke I thought all its bones left it-it was thrown over Board as if dead, yet the moment he toucht the Watter he swam for the Boats-so tenacious of Life are these animals that it tooked a heavy blow of the Axe to finish him-Tomorrow We Hope to Pass the Last Dificulty \& Two Days More May take us to the Mississipi. 
Total Length of the Fin Tailed Duck $15 \frac{1}{2}$ Inches$\frac{3}{4}[--]$ to [-] of Tail Bill Dark Blue, Broad for the size of the Bird-\& sharply hook at the point-Legs \& feet L. Blue the palms Black, Tung fleshy-upper Part of the Head [Dark Brown,] Back Wings-\& Tail Dark Brown Zig Zags with transversal Bars-of Light Do-Sides Dark Chestnut Eye rather small Neck Breast \& Belly Light Brown with transversal Black drops-A Triangular White spot forms the under Tail Coverts-

Tail composed of $r 8$ Feathers rounding each feather narrow Sharp \& Terminating in Spoon Like Shape Points-this is White-the Head \& Neck Short \& Thick-Swims Deep with part of the Belly Silvery white

Breadth 22 Inches-Wings Brown not reaching the Tail by $\frac{1}{2}$ Inch-No Wing Stripe-

When I saw these Birds the Weather was Boisterous since fair have not seen one-

Imber Diver Weighes 6 lbs

Total Length $28 / 12$ feet-

to end of Tail $24 \frac{1}{2} /$ r $2-$ " -

Weidth tip to tip 4

Length of the Gut $58 / 12$ “

Contents of gut \& Gizzard Small Fish, Bones \& Scales and Large Gravel-_Body extremely fat rancid-Belly \& Vest White but not silvery as in the Grebes- 


\section{WEDNESDAY I $^{\text {th }} 1820$ November-}

At Work again this morning as early as could be, a beautiful day-finished My Drawing to my liking having Sketch ${ }^{d}$ our Boats in the View of this Magnificient Part of the Ohio $=$ Saw more than a Dozen of Eagles and one I had a good view of had a White Tail \& a Brown head, Again [Yet] I remark that the Brown Eagles In Ohio Esp. were at Least $\frac{1}{4}$ Larger than the White headed ones

Saw a Large flock of Large White Gulls with Black Wing Tips very shy while on the Wing but not at all so when swimming fired two guns Without affect

Passed the famous Chain of Rocks, Much diversion to see Mr Aumack's Movements-

having seen Steam Boats allmost every day fast on Sand Barrs I have taken no particular notice of any of their Names \& Positions-have Passed this day 3 flat Boats belonging to $\mathrm{W}^{\mathrm{m}}$ Noble of Cincinnati that left that Place early in August-3 out of 6 are lost

Landed about 2 Miles above New America on the Illinois Shore-Broken Land, fine Timber of Oak \& Poplar = Killed an Oppossum-

Our People Much MELowed; Saw Winter \& Shore Larks Many Geese \& Ducks 2 Swans- 


\section{A UDUBON JOURNAL}

\section{Thursday November $16^{\text {th }}$, I 820}

We floated only about Two Miles \& Landed at America - to sell some Articles; people very sickly, a miserable place altogether-took a long Walk this Morning-[and] this afternoon Cape C. Joseph \& I took a Skiff and spent the afternoon hunting, but killed nothing-Saw Two Black Hawks =

At our Return at Night found $\mathrm{M}^{\mathrm{r}}$ Aumack in Bad humor, and after We had retired to our Cabin for the Night, Received a Humorous Lesson that I shall Never forget-

My Dear Children if Ever you read these trifling remarks pay your attention to what follows-

Never be under what is Called obligations to Men not Aware of the Value or the Meaness of their Conduct

Never take a passage in any State or Vessel without a well understood agreement between you \& the owners or Clerks \& of all things Never go for Nothing if you Wish to save Mental Troubles \& Body Viscisitude

Well aware that I shall never forget this Night as Long as I live, I close [here]

The old Washington Steam Boat came along side of us Took 70 barrels of salt rais ${ }^{\mathrm{d}}$ steam and made herself fast about 2 miles Below- 
Friday November I 7 th 1820

We left early-I took the Skiff and Went to the Mouth of the Ohio, and round the point up the Misisipi-

Eleven Years ago on the 2 of January I ascended that Stream to St. Genevieve Ferdinand Rozier of Nantes my partner in a Large Keel Boat Loaded with Sundries to a Large Amount our property

The $10^{\text {th }}$ of May I8I9 I passed this place in an open Skiff Bound to New Orleans with two of My Slaves-

Now I enter it poor in fact Destitute of all things and reliing only on that providential Hope the Comforter of this Wearied Mind-in a flat Boat a Passenger-

The meeting of the Two Streams reminds me a little of the [Young,] Gentle, [man] Youth who Comes in the World, spotles he presents himself, he is gradually drawn in to thousands of Dificulties that Makes him wish to keep [to himself] apart, but at Last he is over done [and] mixed, and lost in the Vortex-

The Beautifull \& Transparent Watter of the Ohio when first entering the Misisipi is taken in small Drafts and Looks the More aquable to the Eye as it goes down surrounded by the Muddy Current, it keeps off as much as possible by running down on the Kentucky side for several miles but reduced to a narrow strip \& is lost-I saw here two Indians in a Canoe they spoke some French, had Bear traps, uncomonly clean kept, 


\section{A UDUBON JOURNAL}

a few Venaison hams a gun and Looked so Independent, free \& unconcerned with the World that I Gazed on them, admired their Spirits, \& wished for their Condition =here the Traveller enters a New World, the current of the stream about 4 miles per hour, puts the steersman on the alert and awakes him to troubles and difficulties unknown on the Ohio, the Passenger feels a different atmosphere, a very diferent prospect-the Curling stream \& its hue are the first objects-the caving in of the Banks and the Thick Set Growth of the Young Cotton Wood is the next = the Watter's dencity reduced the thermoter from 62 to 20 degrees = We Landed Very Early, Cap ${ }^{\mathrm{e}}$ C \& I Walked Through the Woods, and remark ${ }^{d}$ the Great Diference of Temperature so suddenly felt-

I bid my farewell to the Ohio at 2 o'clock P.M. and felt a fear gathering involuntarily, every moment draws me from all that is Dear to Me My Beloved Wife \& Children-

The Boats separated on Entering the Mississipi, as being safer to navigate it singly-We felt the better for this and Hope good Cheer will revive again-

Although I hunted a good Deal this Day I saw but Little and Nothing New, a few King Fishers, some Divers, Geese Ducks-some Gold Finches the Notes of Which reminded Me of the Canary Birds, a few Blue Geays, Now \& then the Plaintive farewell note of the Blue Bird: rather sorry that the Strong Current 


\section{A UDUBON JOURNAL}

we are in Will Not permit Me to go a Shore unless Landed by the force of Contrary winds-

The Mississipi is a good Midle Stage at present

\section{Saturday November i $8^{\text {th }}$ I 820}

floated within about 2 miles of the Iron Banks and Land in Kentucky at about $\frac{1}{2}$ past 3 oclock-

I took a sketch of the River below us comprehending on our Left the Iron Banks, the Chalk Bank on our Right in the Back ground Wolff Island and Part of the Missoury shore.

My drawing finished took a Walk in the Woods, the Country full of Ponds of Stagnant Watters, Shot 2 Malards While Dash was bringing out the Last one a White headed Eagle Dashed at the Duck the Bitch brought it-

Killed an Oppossum Many Blackbirds the Thermometer at 64. Bats in the Evening and Butterflies seen to day in quantity as well as many other InsectsThe Game Not so plenty as on the Ohio and Much Shier-

\section{Sunday $19^{\text {th }}$ November 1820}

When We Left Cincinnati, we agreed to shave \& Clean completely every Sunday=and often have been anxious to see the day come for certainly a shirt worn one week, hunting every day and sleeping in Buffalo robes at night soon becomes soiled and Desagreable. 
We pass this morning the famous Wolf Island, the history of which is amply given in the Ohio Navigator - here said Mr. Lovelace a Man [of] called White having become a Lunatic as I was going up the River, jumped over Board in the Night made the shore although he could not swim and I was then at anchor in 7 feet of watter and never seen afterward, I sent several hands to Look for him, his tracks only Led to the Top of the Bank-the Muskitoes being then remarkly Bad-he must have Died in the Same Bend of the River found 2 dead men shot through the head could not burrie them their stench was too great-

We floated to day almost 20 Miles Killed Nothingsaw Mr James Asler who told Me that Mr Thomas Litton \& himself Lived with a Mile of Chalk Banks-

Ivory Billed Wood Peckers are Now Plenty, Bears, Wolf, \& c but the Country extremely Difficult of Access, the caves Extending in Many Places several Miles from the River-

On Sundays I look at My Drawings and particularly at that of My Beloved Wife-\& like to spend about one hour in thoughts devoted to My familyLanded opposit the Head of $\mathrm{N}^{\circ} 8$. at the foot of $\mathrm{N}^{\circ} 7-$ in Missoury-put out our Lines caught a Cat fishWeather agreable,

Saw Many Gulls-unknown-

the Woods deserted almost by small Birds-Saw four Partriges- 


\section{A UDUBON JOURNAL}

The Wild Geese here sits on the Banks Many feet above Watter and feed on the seeds of a small grape somewhat resembling $F_{0} l$ Avoine-but are extremely shy-

\section{Monday $2 \mathrm{O}^{\text {th }}$ November 1820}

The winds on this River are Contrary to our Wishes as that of an Ole Rich Maid to the wishes of a Lover of Wealth, We are anxious to Make progress on account of our Situation-but it is disposed off Diferently by a Superior Power

We Came but a few Miles and Landed about Noon in Such a Dreary place that Neither the Woods Nor the Stream would afford us any benefit-it rain ${ }^{d}$ in the evening-

Killed to day a Red Tailed Awk a great distance with a Ball-a Red Owl Strix Asio-one goose-Nothing in the Woods that are rendered almost Impenitrab by the Caves-being on a Very Loose Muddy Ground caught no fish-

\section{Tuesday November $2 \mathrm{I}^{\text {st }}$ I 820}

The Wind High all Day Landed at New Madrid at 3 o'clock P.M.-

This allmost deserted Village is one of the poorest that is seen on this River having a Name; the Country Back was represented to us as being good, but the Looks of the Inhabitants contradicted strongly their 
assertions-they are Clad in Bukskin pantaloons and a sort of Shirt of the same, this is seldom put aside unless so ragged or so Blooded \& Greased, that it will become disagreable even to the poor Wrecks that have it on-

The Indian is More decent, better off, and a thousand time more happy-here familly dicensions are at their Zenith, and to Kill a [man] Neighbour is but More than a Kill Deer or a Racoon-

A $\mathrm{M}^{\mathrm{r} s}$ Maddis formerly the Lawfull Wife of $\mathrm{M}^{\mathrm{r}}$ Reignier of St. Genevieve resides and keeps a small store in Company with a French Gentleman. We where told that the Partnership was rendered agreable to both by a mutual wish of Nature-Went to this Lady's house who knew me first and exibited much of the french Manners

Felt dull, this evening for every object that brings forward the Background of My Life's Picture shew too often with poignancy the diference of situation-

Made some inquiries about the regulations of the Post office, now suficiently encouraging to enable my writing a few Lines to My Beloved Wife \& Son-

Saw some geese, Killed one, \& Golden Plovers and tw Shore Larks-Caught No Fish-

A Black Hawk passed within a few Yards of me to day when I had a Rifle and could Not kill it on the Wing, these Birds become more aboundant as we descend; a few swans are now \& then seen very High, 
AUDUBON JOURNAL

All our Hands Playing Cards untill bed Tim about 9 . oclock $=$ The Swamp Sparrows and Snow Birds are plenty in the High Dry Grass that Lines the Banks of this River, but the Woods have Nothing in More than the Pait Pait Pait of the Monogamous-Wood Peckers-

\section{WednesDay November $22^{\mathrm{d}} \mathrm{I} 820$}

We Left New Madrid at day Break. We had gone but a very Short Distance when The Wind Rose, yet we made as the Best days' run since in this River and Landed after Dark 3 Miles above the Little Prairie on the Missoury Shore-

Joseph \& Myself floated before the Boats almost all day in hunt of a White headed Eagle, in Vain, I shot at \& Missed a Beautifull Black Hawk and a Brown Eagle having a very Long Bend to run through, We helped Mr. Lovelac's; While We when rowing, a White headed Eagle Dashed off from the Top of a High Cypress Tree, after a Little Duck the Spirit and was on the point of being in Possession of it-when I sent him Two heavy Loads from My Gun that Wounded him badly-

I called this Morning at Belle Vue Wood Yard to see $\mathrm{M}^{\mathrm{r}}$ Dela Roderic, he was absent to a Cypress Swamp, I saw his Wife \& Sister, and Left my Respects

the Weather quite Pleasant, although We have Light White frosts every Night-

Some minutes after Landed, Dash started an op- 
possum that took Every Man to Shore thinking it was a Bear, the Poor Oppossum came on Board with usfishing lines all out lost one, and a large Cat Fish in tringig to hawl him in-Geese, Sandy Hill Cranes Plentifull on the Sand Barr opposite us, they regularly resort to these for roost.

\section{Thursday November 23 I 820}

As soon as we had eat our Common Breakfast fried Bacon and Soaked Biscuits-Joseph went to his station and I to Mine, i. e., he rowed the skiff and I steering it-Went to the Little Prairie shot at a Brown Eagle probably $25^{\circ}$ yards and yet cut one of its legs-

at this Place We Saw a great number of Birds, Mostly Red Breasted Thrushes-the sungs of Which revived our Spirits and Imparted within us the Sweet sensation that Spring brings to Minds of our Kind.

the Rusty Grakles extremely Plenty-Snow Birds\& Many Sparows

I shot a Beautifull White headed Eagle Falco Leucocephalus-probably I50 yards off, My Ball Went through its body-

Returned to our Boats immediately and began My Drawings-it is a Handsome Male-

Many Shots at Geese, but We find them so shy that We Loose Much Ammunition in Contending With them-

Floated 23 miles Landed opposite Island No. 20 
according to the Old Navigator, some Indians camped on it, Made us Load all our pieces-

I saw Two Eagles Nest, One of them I remembered seeing as I went to New Orleans 18 months ago it had being worked upon and no doubt young Where raised in it, it is in a Large Cypress Tree, Not very high, Made of Very Large Dead sticks and about 8 feet in Diameter-

Since I killed the one before me I am Convinced that the Bald Eagle and the Brown Eagle are Two Diferent Species-

\section{Friday November $24^{\text {th }}$ I 820}

high Winds, remained at Our Last Night's harbour all day-at Day Break saw a Deer crossing the River below us, ran him down and Brought him to the Boats; Cleaned, it Weighed I/ I $2{ }^{\text {td }}$ had 9 points to its horns and so much run down that its Neck Was swolen $\frac{1}{2}$ the Size of its Body-

I spent the greater part of the day drawing; All hands hunting-Killed Two Geese, I Racoon \& I Oppossum-

the Woods here are so Dreadfully tangled with Bull rushes, Green Briars and Canes that the Travelling through them is extremely Irksome=

Saw some Carrion Crows and some Turkey Buzards that were attracted by the scent?? of the Deer We had hung in the Woods?? 
Immediately below us is a family of Three people in Two Skiffs a Woman \& 2 men; they are Too Lazy to Make themselves Comfortable, and Lie on the Damp Earth, near the Edge of the Watter, have Racoons to Eat and Muddy Watter to help that food down, are from the Mouth of Cumberland and moving to a Worst Part of the Worst Without Doubt-

Saw some Ivory Billed Wood Peckers, these Birds allways go in Paires and when they Leave a Tree to fly to another they Sail and Look Not unlike a Raven. I shot and Killed a Turkey Buzzard a great Distance, Mistaking it for a Carrion Crow-unfortunately we are in bad part of the River for Fish-

\section{Saturday November $25^{\text {th }}$ I 820}

I spent the whole of this day drawing the White headed Eagle, the Weather exceedingly Warm, the thermometer rose to $70^{\circ}$. The wind Blowing Strong a head We remained still; in the Course of the Afternoon a small Steam Boat, the Independence passed us, I saw with the spy glass old Cape Nasson of Louisville; Butterflies, Wasps \& Bees plenty all day about usthe Skiff family of yesterday a few hundred yards below us, the Woman washed for us

At Sunset the Wind Shifted, A heavy Clouds came over us and Made a great difference in the atmosphere-

Killed 2 Geese and Two Racoons-Saw a few Car- 
AUDUBON JOURNAL

rion Crows attracted by the Scent of the Deer We Caught yesterday

Our Hands sailing all day

\section{Sunday November $26^{\text {th }}$ I 820}

Drawed all day, floated i 8 Miles-the family in the Skiffs came on Board this Morning. Nearly frozen, the Thermometer down at 22-the ground very hard, and my being without a Shirt-Made Me feel rather unpleasant.

the Woman of the Skiffs Mending My Good Brown Breeches--

to Look on those people, and consider cooly their Condition, then; compare it to mine; they certainly are more Miserable to Common Eyes-but, it is all a Mistaken Idea, for poverty \& Independance are the only friend that will travel together through this World.

Shot at an Eagle With a White head and Brown Tail.

Ducks, Geese, Swans, \& other Birds all going southwardly-

\section{Monday November $27^{\text {th }} 1820$}

the weather raw and Cloudy. Finished my drawing of the White headed Eagle, having been 4 days at it-

That Noble Bird weighed $8 \frac{1}{2}^{\mathrm{lb}}$, Measured 6 feet 7/2/1 2 his Total Length 2:7/2/12 -it proved a Male, the heart extremely large, My Ball having passed 
through his Gizzard I could not see any of the Contents-

Those Birds are becoming very Numerous, hunt in pairs, and roost on the Tall trees above their NestsOne this morning took up the head of a Wild Goose thrown over board, with as much ease as a man could with the hand-they chase Ducks and if they force one from the Flock he is undoubtedly taken, carried on a Sand Bank and eat by Both Eagles-they are more shy in the afternoon than in the morning-they seldom sail High at this season, Watch from the tops of trees and Dash at any thing that comes near them - to secure a Goose, the Male \& Femelle, Dive alternatively after it and give it so little time to breath that the poor fellow is forced in a few Minutes.

We are all unwell having eat too freely of the Buck. $M^{r}$ Shaw went off this morning to Mr Lovelace's boat -Made a good run-saw a Large Flock of White Gulls-but not a Land Bird-Much to My surprise I have not yet seen a Pelican, nor a Swan on the Barrs or in the River-Malards are the only Ducks we now see-No Game, to be procured Not able to hunt on the shores-We are Landed at the foot of Flour Island, opposite the first Chicasaw Bluff-the First High Ground since the Chalk banks-

While Looking at My Beloved Wife's Likeness this day I thought it was altered and Looked sorrowfull, it produced an Immediate sensation of Dread of her 
being in Want-yet I cannot hear from her for Weeks to Come-but Hope she and our Children are WellThe Eagles along the Banks of this River, retire in bad weather to the Inner parts of High Cypress Woods and remain on Low Limbs for whole day, I had an opportunity of seeing several from our Landing place, with my spy glass.-

\section{TuesDay November $28^{\text {th }}$ I 820}

As it is a rainy morning, I cannot, hunt, and will take this opportunity to retaling to you such incidents relative to my Life as I think you may at some future period be glad to know-

My Father John Audubon, was born at Sables D'Olorme in France; the son of a man who had a very Large familly, being 20 males \& one femelle. his Father started him at a very early age Cabin Boy on Board a Whaleing Ship-of course [his youth his] by education he was [no more than what is call here w] nothing; but he naturally was quick, Industrious and soberly Inclined; his voyage was a hard one but he often assured me that he never regretted it-it rendered him Robust, active and fit to go through the World's rugged paths. He soon became able to command a Fishing Smack, to purchase it, and so rapidly did he proceed on the road of Fortune, that when of Age, he commanded a small Vessel belonging to him, trading to St. Domingo- 
A Man of Such Natural Talents and enterprise could not be confined to the common drudgery of the Money Making Annimal, and entered an officer in the French Navy's Service under Louis the I $^{\text {th }}$ was fortunate and Employed an Agent at St. Domingo to Carry the trade-Every movement was a Happy hit, he became Wealthy=the American Revolution brought him to this Country Commander of a Frigate under the Count Rochambeau, he had the honor of being presented to the Great Washington, and Major Croghan of Kentucky who has told me often that he then Looked Much Like me was particularly well acquainted with him. My Father was in several Engagements in the American service and at the taking of Lord Cornwallis-

Before his Return to Europe he purchased a Beautifull Farm on the Schuillkill and Perkioming Creek in Pennsylvania; the Civil Wars of France and St. Domingo, brought such heavy ravages of Fortune on his head, that it was with the utmost Dificulty that his Life Was Spared-

he along with thousands now saw his Wealth Torn from him, and had Little More left than was Necessary to Live and Educate Two Children Left out of fivehaving 3 older Brothers killed in the Wars-

he remained in France reentered in the Service under Bonaparte; but the French Navy prospered not and he retired to a Small [but] beautifull Country Seat, 


\section{A UDUBON JOURNAL}

Three Leagues from Nantes in Sight of the Loire and ended his Life happy $=$ Most Men have faults, he had one that never Left him untill sobered by a Long Life common to Many Individual, but this was Counter balanced by Many qualities-his Generosity was often too great-as a Father I never complained of him and the many Durable Friends he had prove him to have been a good Man-

\section{[Two lines blotted out here]}

My Mother, who I have been told was an Extraordinary beautifull Woman, died shortly after my Birth and My Father having remaried in France I was removed thereto when only Two Years Old and receive by that Best of Women, raised and cherished [by her] to the utmost of her Means-My Father gave me and My Sister Rosa an education appropriate to his purse. I studied Mathematicks at an early Age, and had many Teachers of Agreable Talents. I perhaps would have much stored up, if the Continual Wars in Which France Was engaged had not forced me away when only Fourteen Years Old = I entered in the Navy and was $\operatorname{Rec}^{\mathrm{d}}$ a Midshipman at Rochefort Much against my Inclinations-the Short Peace of 1802 between England \& France ended My Military Carreer [-]. \& [but] the Conscription determined My Father on sending me to America and Live on the Mill Grove Farm I have mentoned above-he sent me to the care of Miers Fisher, Es ${ }^{\mathrm{qr}}$ a rich and honest Quaker of 


\section{AUDUBON JOURNAL}

Philadelphia who had been his agent for many years, and who received me so Politelly that I was sure he Esteemed My Name-

A Young Man of Seventeen sent to America to Make Money (for such was My Father's Wish) brought up in France in easy Circumstance who had never thought on the Want of an article I had had at Discretion, was but ill fitted for it-

I spent much Money and One Year of My as Happy as the Young Bird; that having Left the Parents sight carolls Merily, While Hawks of All Species are Watching him for an easy prey

I had a Partner with whom I did not agreed, he [- - - ] [tried] waited his opportunity $[-\ldots--]$ [that] We parted forever.

Here it is well I should Mentioned, that I Landed in New York, took the Yellow Fever and did not reach Philadelphia for Three Months-

Shortly after My Arrival on My Farm, Your Mother Lucy Bakewell came with her Father's Familly to a Farm Called Fatland Ford and divided from mine only by the [road going from] Philadelphia Road.

We soon became acquainted and $I$ attached to her. I went to France to Obtain My Father's Consent to Marry her, and returned with a Partner, Ferdinand Rozier of Nantes entered in Business for the thoughts of Marriage brought Ideas so new to me that I [entered] began with pleasure in the [Business] War to 
secure my Future Wife and Familly the Comforts We had both been used to-I travelled through the Western Country and Made Louisville my Choice for a residence-On my return and being of age I married your Beloved Mother on the $5^{\text {th }}$ of April 1808 and removed to Kentucky-Louisville did not suit our Plans and we left that place with a View to Visit St. Louis on the Mississipi; but it is so seldom that our Wishes are favored that we did not reach that Place, for My Partner not being on good Terms with My Wife, I left her and You Victor at Henderson, you when there a babe, having reached St. Genevieve through Many Dificulties, Ice, \& ${ }^{c}$ I parted from $M^{r}$ Rozier and Walked to Henderson in Four Days 165 Miles.

Your present Uncle T. W. Bakewell Joined me in opening a House at New Orleans that the War with England Made us Remove to Henderson.-

This Place saw My best days, My Happiest, My Wife having blessed me with Your Brother Woodhouse and a sweet Daughter I Calculated, to Live and died in Comfort, Our Business Was good of course We agreed. but I was intended to meet Many Events of a Disagreable Nature; A Third Partner Was taken in and the Building of a Large Steam Mill, the Purchasing of Too Many goods sold on Credit of course Lost. reduced us-Divided us-

Your Uncle who had maried a Short time previous $46 \sim$ 


\section{AUDUBON JOURNAL}

removed to Louisville-Men with whom I had Long been connected offered me a Partnership. I accepted and a small ray of Light reappeared in My Business but a Revolution occassioned by a Numberless quantities of Failures, put all to an end; the Loss of My Darling Daughter affected Me Much; My Wife apparently had Lost her spirits. I felt no wish to try the Mercantile Business. I paid all I could and Left Henderson, Poor \& Miserable of thoughts.

My Intention to go to France to see My Mother and Sister was frustrated, and at Last I resorted to My Poor Talents to Maintain, You and Your Dear Mother, who fortunately [now] apparently became easy at her Change of Condition, and gave me a Spirit such as I really Needed, to Meet the surly Looks and Cold receptions of those Who so shortly before where pleased to Call me Their Friend.

in Attempting the Likeness of James Berthoud, Es ${ }^{\text {qr }}$ a Particularly good Man and I believed the Only Sincere Friend of Myself and Wife We ever had-to please his Son \& Lady I discovered such Talents that I was engaged to proceed and succeeded in a Few Weeks beyond my Expectations.

Your Mother who had remained at Henderson to come by Watter, was at Last obliged to come in a Carriage, and for the second time You had a sweet sister born. How I have dwelt on her Lovely features, when sucking the nutritious food from her Dear 
Mother-Yet she was torn away from us when only 7 months old = having taken all the likeness Louisville could afford I removed to Cincinnati, leaving you all behind untill satisfied of some Means of Making something for a Maintanance-Through Talents in stuffing Fishes I entered in the service of the Western Museum at One hundred and Twenty five Dollars per Month, and raised a Drawing School of 25 Pupils, Made some Likeness, and had You around Me Once More-but small towns do not afford a support for any time.

Ever since a Boy I have had an astonishing desire to see Much of the World \& particularly to Acquire a true Knowledge of the Birds of North America, consequently, I hunted when Ever I had an Opportunity, and Drew every New Speciman as I could, or dared steel time from my Business and having a tolerably Large Number of Drawings that have been generally admired, I Concluded that perhaps I Could Not do better than to Travel, and finish My Collection or so nearly [so] that it would be a Valuable AcquisitionMy Wife Hoped it might do Well, and I Left her Once More with an intention of returning in Seven or Eight Months; I wrote to Henry Clay Es ${ }^{\text {qr }}$ with Whom I Was acquainted and he Enclosed Me in a Very Polite \& Friendly Letter One of General Introduction $=\mathrm{I}$ received Many from Others-General Harrison, \& from the day I left Cincinnati untill the present My Journal gives you a rough Idea of My Way of $48 \cdots$ 
Spending the tedious Passage in a Flat Boat to New Orleans-

We moved from our Landing of Last Night and only crossed the River for the rain Lowered the Smoake so Much that it was impossible to see, beyond 20 or 30 Yards; played great deal on the flutes, Looked at My Drawings, read as Much as I Could and yet found the day very Long and heavy for Although I am Naturally of light spirits and have often tried to Keep [my spirits] these good, when off from my Home, I have often dull Moments of Anguish-[it stopped] the rain abated for a few Minutes. Cape C. Joseph \& I took a Walk to a Sand Barr Where Joseph Killed a Large blue Crane, unfortunately a Young one-saw few Geese, many Cardinals, some Carolina Wrens-We are better to day-[fortunatly] Luckily our Boat does not LeekSaw a few Purple Finches=

\section{Wednesday November $29^{\text {th }}$ I 820}

the rain that begun two days since, accompanied us the whole of this day, yet We Left our Harbour at about 7 this morning and removed 20 miles-We passed the second Chicasaw Bluff, raining so much that I could not draw them; they are Much More Interesting than the Chalk Banks indeed they Look grand and Imposing. they are from 150 to 200 feet High Irregularly Caving down and Variegated in stratas of Red, Yellow, Black, and deep Lead Colors, 
the Whole of Such Soapy and Washing Nature as to give an interesting contrast by the Dashing of the Wash down to the edge of the Watter which here is very deep the upper Strata (the whole run horizontal) is perferated with Thousands of holes, the Nests of the Bank Swallow - these Bluffs are about two Miles $\frac{1}{2}$ Long, the Country back, Barren \& Poor-

Confined to the Inside of the Boat nearly the day, saw but a few Gulls, apparently all White, some White headed Eagles, \& a few Cranes-a Large flock of Gold Finches-a few Blue Geays, \& Cardinals, the Ivory Bill Wood Peckers heard from time to time,-

We are Landed at the foot of $N^{\circ} 35$ a few miles above what the Navigators call the Devil's Raceground-but the whole of the Mississipi being so much of the same nature, it feels quite immatereal to follow the Devil's tracks any where along its Muddy Course-

\section{Thursday Novembr $30^{\text {th }} 1820$}

We found the race path of the Devil well cleared and beaten, and went through it with great Ease, Many places on this River are rendered More terrible in Idea by their Extraordinary Names than real dificulties-

We run a Race with Mr Lovelace's Boat of several miles that was well nigh terminating in a dispute-it reminded me of Gamblers that although playing for Nothing are allways grieved by Lossing- 
We came 25 Miles and Landed a little below the Twelve Outlets, passed the third Chicasaw Bluffs, the view of those was intercepted by our Running on the Right of an Island-the Weather Cold, \& very Disagreable, Wind blowing all day mostly ahead = Some Men came on Board Mr L. Boat who said had Killed Three Bears a few days' before-saw a few Indians at a Small Encampment-this morning I remarked Two Flocks of American Teals flying up the River; the Parokeets Numerous in the Woods-a Large flock of Sand Hill Cranes Sailed over us for some time, sounding \& Elevating themselves to a Considerable Hight took a southwardly course-One Swan was seen on a Barr, but so shy that he flew several times at shore as he perceived the Boat. Whenever We Land a Number of Swamp Sparrows are seen [Sku] Scullking through the High Grass that borders the Banks, the seeds of Which are the heath or more properly Mud; the Geese feed freely on these Whilst the Grass affords them an agreable place during the day-Saw a few Gulls, a Large flock of Sprig Tail Ducks going all southwardly-the Cedar Birds Ampellis Americana fly northeast.

We passed this afternoon I9 Flat Boats Lying at the Shore, some of which had Left the Falls ro days previous to our Departure-

I saw to day 2 Common Crows the only I have seen on the Mississipi- 


\section{A UDUBON JOURNAL}

\section{Friday December I ${ }^{\text {st }}$ I 820}

This Morning was Cold and Cloudy, Flocks of Ducks Geese, \& flying High plentifully, all bound to the Southwest-I remarked Large Flocks of Merganzers, I Mean, The Large. These Birds seldom Leave, the Clear Ohio or its tributary streams untill Compelld by the Ice Closing most parts of them; their passing southwardly so early indicates a severe winter above us $-A$ their Flight is Direct, regularly formed in Acute Angles and so swift that one might suppose the noise over head as proceeded from a violent storm of Wind -Saw Early to day several Hundreds of Gull, playing over a Large Barr-When We attempted to Close on them, they rose high and off South-4 White headed Eagles where at the same time regalling themselves on the Carcass of a Deer-The sworms of Grakles that are passing us is astonishing-the Purple Finches also very Numerous saw several hundreds in one flock -Where the Weather is Intensely Cold, scarcely a Fowl is to be seen along the Banks, the ponds offering themselves at that time food \& Shelter Passed a Large Settlement of Wood Cutters-Mr Shaw killed 5 Geese 4 at one shot saw two Slate Colored Hawks, Falco Pennsylvanicus and a Winter Hawk. I went a shore to a House about 5 Miles above Wolf River in a sharp running Bend, saw 2 beautifull Trees the Pride of China here the High Land is within 2 miles of the 


\section{A UDUBON JOURNAL}

River and the spot on which the Plantation stands never overflows, these are remarkable spots-

We are Landed immediately at the foot of Old Fort Pickering. We Walked up to it through a very narrow crooked path, and found in a very decayed situation; the Position a Beautifull one the Land Rich about itand were told that the Spaniards own it it was an agreable spot to Live at-about 2 Miles above this, the Mouth of Wolf river came in from the East, and is the Landing place of a Town Called Memphis = have runned 24 miles-Saw some Towe Buntings and Many Sparrows-[The following paragraph is written across page]

At New Orleans on the $25^{\text {th }}$ of February same year saw an a/c in a New York Paper saying that the Weather had been Intensely severe that the Mercury had been so Low as 24 Degrees below o = that the Port of New York was completely closed by Ice and that all the Streams in that state \& Pennsylvania where closed-Much pleased to see that particularly the Migrations of a swift Moving Bird such as the Merganser can so truly be considered as the herald of Weather in its Movements when going Northward \& Southwardly

at the Watter Edge (then about midle Stage) there is a Bed of Coals running Orisontally about 2 feet Deep above the surface-this and the Eligeability of the Situation May become Valuable- 
I saw this afternoon Two Eagles Coatiting-the femelle was on a Very high Limb of a Tree and squated at the approach of the Male, who came Like a Torrent, alighted on her and quakled shrill untill he sailed off the femelle following him and zig zaging herself through the air-this is a scarce proof I have had the pleasure of witnessing of these and all of the Falco Genus breeding much Earlier than any Other Land Birds-

We lost one of our Fishing Lines, a Large Fish Must have Carried it, its being very Strong and Well fastened to a Strong Willow Pole-

The Beard of the Turkey shews about one Inch Long the I $^{\text {st }}$ Year, and one of the Male in full growth and plumage must be 3 Years old=

So well exercised are the Geese at extricating themselves from danger when a Flat Boat Comes Near them that they will Walk off from the Edge of the Watter out, into the Young Willows \& Cotton Wood several Ioo yards-but when in a Bend where the Shore is Steep they May be reached With more Ease.

\section{Saturday December $2^{\mathrm{d}}$ I 820}

Cloudy \& Cold, took the Skiff and went ahead of the Boats, the only way I have now of hunting, and when any game is on Sight Lay down in the Bow and float untill distance-Shot at a Large W. H. Eagle and a Black Hawk Missed both, this Latter in going 
off flapped his Wings Like a Pigeon, they more Swifter than any bird in their Common flight. I could Not Well account My Missing these Birds, they were not More than Ioo $\mathrm{y}^{\mathrm{d} s}$ off-I shot 3 Turkeys at 2 shotstheir Crops completely filled with winter Grapes [their] Gizzards of the seeds of the same and large gravel. They were extremely gentle [and] I floated immediately to them and Came within $25 \mathrm{y}^{\mathrm{ds}}$. Cold days force the geese away from shore--the Woods Literally filled with Parokeets great Many Squirels-and Many Snow Birds-begun raining at about one-Now \& then a Wood Cutter's Hut is seen in a Small Parcel of clear $^{d}$ Land between Two Thick Cane Brakes-

The Lights or Pulmon of the Turkeys I Examined This Day, had much the appearance of Waddles connected by a Thin Skin, the Wadles about $\frac{1}{2}$ Inch Long $=$ the Thin Skin about $\frac{1}{4}$ of an Inch-

Many Golden Wings Woodpeckers-a few Sparrow Hawks

We Landed on What is Named a Tow head a little above the Island $\mathrm{N}^{\circ} 5^{\mathrm{I}}-\mathrm{a}$ Tow head is a small Willow Island overflown in High Watter-

in was Not Dark and We Walk Round it-Saw Many Geese, and a Young Bear, but its being so late $\&$ dark Was Called out, and gave it up.-

Raining \& very Disagreable-Many Gulls flew about us to day and Picked up the Lights \& fat of the Turkey, \& Geese that Were thrown over Board 


\section{A UDUBON JOURNAL}

\section{Sunday December $3^{\mathrm{d}}$ 1820}

It rained Heavy all night, this morning it was concluded the boats would not Leave, yet our Captains went hunting the Wind Blowing at Intervals and then ceasing, made some diference of the force of the rain $=$ Saw several Crows Many Brown Larks, Many Geese, and Malards = Killed to day 3 Geese, 2 Malards and 2 Mergansers, both femelles measuring 25 Inchesthe Bill \& Legs Not so bright a cealing Wax Color as usual-tongues sharp Triangular and Toothedthink them young-one of them had Caught a Fish about 9 Inches of the Sucker Kind and had only partly down its throat when Killed-there was 5 together we drove them several times out of a Pond in the inner part of an Island and at Last Shot these on the Wing = the Geese very Shy-Three Keel Boats passed us about 2 o'clock P.M. - they had left the Falls of Ohio 3 weeks ago-Left our Harbour and floated about 4 Miles to the foot of Buck Island-here I saw with the setting sun hundreds of Malards travelling South and the Finest rainbow I ever beheld, the Clouds were also beautifull apposite it=Looked at my Beloved Wife's Likeness Shaved and Cleaned One of the few enjoyments Flat Boats Can afford-the Goose we eat at Dinner extremely fishy.

Joseph who now is obliged to officiate as Cook does not appear to relish the thing-the more I see Cape C 
the more I Like him $=$ Wish that we could say the same of all the World-

The Towhead on Little Island on Which Laid Last Night and to day had Vast Many dry Nests of Thrushes on the small Willow Trees-the Tall Grass with many Sparows-Saw 2 Flocks of Partridges, Many Parokeets. Saw a Blue Crane.

\section{Monday December $4^{\text {th }}$ i 820}

We had a dreadfull night of Wind, the hands obliged to move the boats. I did not sleep, the Knocking of the Boats against the Sand Barr very desagreable-This Morning the Wind still blowing hard. Went to a Small Lake to Shoot-there I saw a Killdeer plover, a King Fisher; Many Geese \& Ducks-but no Swans as we had been led to expect from reports of a Squater-Killed 3 Geese, and 3-American Teals-Saw a few Turkeysthis Lake about 2 Miles from the River, contains some of the Largest Muscles I ever saw, and Vast Many perewinkles that appear to be of a Peculiar Species and I put some in My pockets-I found these in round Parcels of about 20 to 30 close together-My Slut Dash brought out of the Watter very well-When returned to our Boats, 9 of the Boats we had passed some days previous went by, and we pushed off immediately-We floated only about 4 miles-and Landed on the Tennessee Shore-

Saw to day great Many Autumnal Warblers, the first 


\section{AUDUBON JOURNAL}

I have seen since on the Mississippi, a few Crowes some Winter Wren, some Eagles W. $H^{d}$-it is very Seldom that brown Eagles are seen; - the others are now courting seeing them every day chasing off the Batchelors-

I doubt not that the Migrations of the Autumnal Warblers is the latest of all that Genus-

I was taken off Suddenly a few Minutes ago to take a Cat Fish of our Line. I had some trouble for a few minutes but having drowned him put my Left hand in his Geels and hauled it in the Skiff-it weighed $64^{\frac{1}{2}}{ }^{\mathrm{b}}$ and Looked fat-Killed it by stabbing it about the Center of its head, this was so Effectual that in a few Second it was quite Motionless-

I would be Inclined that, from Shape, Size, Color \& Habits so diferent to that of the Cat Fish Caught in the River Ohio the present one is a diferent Species.

\section{Tuesday December $5^{\text {th }}$ i 820}

Skinning the Cat Fish was the first Job this morning-this was done by cutting through the Skin (which is very Tough) in Narrow Long Strips and tearing those off with a Strong Pair of PincersWhile at this saw Several hundred of those Black Birds yet unknown to me that I denominate Black Pelicans flying South forming a very obtuse Angle, without uttering any Noise-have some Hopes therefore to see some of them on the Watters of Red River 


\section{A UDUBON JOURNAL}

or Washita-Sand Hill Cranes were also fling and We saw More Geese than usual-Joseph Killed 4 American Teals-those fly up stream-saw 3 Swans-While Geese are flying in a Travelling order the Young or Smallest are about the center of the Lines and the Larger Gander Lead the Van, the Oldest Goose Drives the Rear-the Weather beautifull but cold, and No Doubt that the Frogs that Wistled so merily Yesterday are well buried in the Mud this Morning-

We made an Awkward Landing, Lodged in the Mud for about $\frac{1}{2}$ an hour, and our Commander had a good opportunity of Exercising his Powers at SwearingMore particularly when Anthony broke his Sweep Oar. this Took Place about 30 Miles from our starting place of this Morning, [at the foot of No] opposite the head of 57 \& 58 - "fine Weather but No Fish" says Cape Cummings--

\section{WednesDay December $6^{\text {th }}$ I 82 I}

Light frost, Rich Clouds of Purple \& Light Green Indicates Wind-extremely anxious to overtake the fleet ahead our Commanders have yesterday and this morning exerted themselves more than usual and have left our harbours as soon as Day Light would permithow beneficial a fleet constantly a head Would be!-

Saw 2 Large White Cranes with Black Tips-too Shy to get in floating distance;-Many $\mathrm{A}^{n}$ Teals and as Many Geese as Ever- 


\section{A UDUBON JOURNAL}

Passed the St. Francis River the mouth of which at this time appeared Closed by a Mud Barr-but the people who Lived on the Point formed by that stream and the Mississippi told us that there was plenty, and that Keel Boats go up it 400 Miles, many settlements on the banks the first about I 5 miles-the Same people told us that they had seen many Pelicans a few days previous in Passing-saw some Old Blue Cranes on the Trees but could not go within I5o yds of any of them - a Little before we passed the Place called the Big Prairie shot a Monstrous Turkey Cock, I think the Largest I every saw; it appears considerably Larger than one I weighed that was over 3 I $l b-M y$ anxiety to have it Made Me Miss-the Big Prairie is a Tolerable sized Plantation rather higher than usual on this River, about $\frac{1}{4}$ of a Mile Back-the Land rises in Gentle Hills, and when told is extremely Rich there, I first saw the Mississippi Kites ${ }^{a}$ : ascending in the Steam Boat Paragon in June 1819-Bought some Delicious Sweet Potatoes at $\frac{1}{2}$ Dollar $\mathrm{p} r$ Bushel the Squater assured me that a few Weeks previous, the Pelicans were so numerous that Hundreds where often in sight on a Barr below this Place-people very sicklyLanded on the Tennessee Shore about 7 Miles from the Settlement of the Hills. the Wonderfull fleet still about 4 miles a head, our Comodores had a Meeting, the result was that We should Start one hour before day and run down the $\mathrm{D} d$ Rascals- 


\section{A UDUBON JOURNAL}

[The following lines in the diary are put on a blank space of the preceding page as an explanation.]

a The Mississippi Kite Were Busily Employed in Catching small Lizards off the Bark of Dead Cypress Trees, this effected by Sliding beautifully by the Trees and suddenly Turning on their Side and Graple the prey-having At that time no Crayons or Paper, did not Draw one, and determined Never to Draw from a Stuffed Specimen, Carried No Skins-

\section{Thursday December 7 th 1820}

Caught a Nice Cat Fish weighing $29 \mathrm{lb}$. at 3 o'clock this Morning-stabd him as we had the former but it did not die for One Hour-at Day Break the Wind stiff a head, a Couple of Light Showers Lulled it, and we put off-Mr Aumack Winged a White headed Eagle, brought it a live on board, the Noble Fellow Looked at his Ennemies with a Contemptible Eye. I tied a String on one of its Legs this Made him Jump over Board. My Surprise at Seeing it Swim well Was very great, it used its Wings with great Effect and Would have Made the Shore distant there about $200 \mathrm{yds}$ Dragging a Pole Weighing at Least I 5 lbs-Joseph went after it with a Skiff, the Eagle Defended itselfI am glad to find that its Eyes were Coresponding with My Drawing - this Specimen rather less than the one I draw - the femelle hovered over us and shrieked for some time, exibiting the true sorrow of the Constant 
Mate-Prepared a Bed for My Slut Dash expecting her to be delivered from her Burthen every Day-

Our Eagle Eat of Fish freely about one hour after we had him, by fixing a piece on a stick and puting it to its Mouth-however while I was friendly Indian toward it it Lanced one of its feet and caught hold of My right thum, made it feel very sore-

Went to an Eagle's Nest; busily Employed Building Shot at the femelle, which is at all times distinguished by her size, the Male was also asitting-Killd One Goose - as We Reachd the head of the Sand Barr close to Island No 62 We passed the Fleet at anchor but they all pushed off when they saw us go through this Place-One Boat suffered Much, by being runned down by another in Landing-Came 25 Miles-the Evening Looking Stormy, the Current strong as our Landing Could not put out our Lines-Our Comodores Much Elated-

\section{Friday December $8^{\text {th }}$ I 820}

Not satisfied about our Landing in a strong Current I slept but little, Whenever I walk $d$ on the deck the Eagle Hissed at $\mathrm{Me}$, and ruffed itself in the Manner that Owls do generally-the Weather Warm, Cloudy, $\&$ Windy-put off late and only run about $3 \frac{1}{2}$ miles forced by the storm to land at the foot of what I supposed the Island No 63-leaving all the fleet behind us- 


\section{AUDUBON JOURNAL}

with Some Hopes of Shortly being at the Arkansas Fork I feel Inclined to Copy a few of the Letters I had for that Place Particularly those of Generals Harrison \& Lytle.

\section{Dear General}

Cincinnati Sept 7 th 1820

Mr. Audubon who will have the honor to hand you this, is upon a Tour through the Extensive forests of Western America for a Scientific Purpose-that of Completing a Collection of American Birds-I beg leave to Introduce him to you \& to request your aid and [assistance] Countenance in the [highly] accomplishment of his highly laudable project--

Mrs Harrison is well \& my daughter Lucy \& Son Syomms both Maried since you were at my House, the latter to a Daughter of Genl Pikes-

\section{Your Friend \\ W. H. Harrison}

Governor I. Miller

Arkansas $\mathrm{T}-\mathrm{y}$.-

Dear Sir-

Cincinnati Ohio Octr 9th 1820

Permit me to Introduce to your Acquaintance John J. Audubon es $q r$ who is on a Visit to the Territory of Arkansas and the Norwest as an ornithologist --for the taking drawings of Birds-Fowls \&c--for a Work he has on hand. Any facilities You May have it in Your Power to offer him toward promoting the 
Object in view will be thankfully received by him and duly appreciated by

\author{
Yours friend and Hble Servt \\ Wam Lytle
}

\title{
Cincinnati Octr Ioth 1820
}

Revr Gentlemen-

Permit me to Introduce to your Kind regards John J. Audubon Esqr who proposes traversing Louisiana for the purpose of Compleating a Collection of Drawings of the Birds of the U. States which he proposes to publish at some Future Period-he has been engaged in our Museum for 3 or 4 Months \& his performances do honor to his Pencil-

I regreat to hear that you have been visited by Sickness. I Hope you May get Safe to your journey end, $\&$ be prospered in the great \& glorious work on Which you have Entered-I should be Pleased to hear from you frequently

I Remain Your Sincere Friend \& Brother in the Lord

\section{Elijah Slack}

Reverend Veil \& Chapman-

Elijah Slack was then President of the Cincinnati College

Cess des the above I received several Letters from Docr Drake Directed to the Reverend Mr Chapman 64 - 
Osage Mission-Coll Breasly Indian agent \& Governor Miller-

I Will give You here the Copy of the Letters I Received from the Honorable Henry Clay to the one I Wrote from Cincinnati the Copy of Which is annexed at the Beginning of the Part of My Journal

\section{Sir-}

I received your letter of the $\mathrm{I} 2$ th inst and now do myself the pleasure to transmit to you inclosed such a letter as I presume you want-I suppose a general letter would answer all the purposes of special introduction, which I should have been at a loss to give as I do not know the particular points which you may Visit-and even if I did, I might not have there any personal acquaintances-

Will it not be well for you before you commit yourself to any great Expense in the preperation and publication of your Contemplated Work to ascertain the success which attended a similar undertaking of Mr Wilson?

\section{With Great Respect \\ I am Yours \\ H. Clay}

\section{Lexington-25 Augt 1820}

I have had the satisfaction of a personal acquaintance with Mr. John J. Audubon; and I have learnd from others who have Known him longer and better, 


\section{A UDUBON JOURNAL}

that his Character and Conduct have been uniformly good: being about to take a Journey, through the Southwestern portion of our Country with a laudable object connected with its Natural History, I take great Pleasure in recommending him to the Kind Offices of the Officers, and Agents of Government and other Citizens whom he may meet, as a Gentleman of amiable and Excellent qualities, well qualified, as I believe, to execute the object which he has undertaken

H. Clay

H. Clay Was then the Speaker of the House of Representatives, and I Hope to rece some benefits from this Letter-

$\mathrm{Mr}$ Aumack killed a Goose and Joseph an Intrepid Hawk, Swans extremely Plenty fired at them Many Times with Balls without Success-

Drifted at 3 o'clock P. M.-about 4 Miles and Landed at foot of No 64-

I began a letter to My Beloved Lucy with some Hopes of reaching the Fort of Arkansas Tomorrow, but Hopes are Shy Birds fling at a great Distance [and it is] seldom [that] reached by the best of Guns [can reach them]

\section{Saturday 9 th December 1820}

I have nothing to say for this day. I drew a little [today,] seeing a Green Briar with seeds on-Wrote to My Lucy and Lived on Sweet Potatoes-how Surly 
the Looks of Ill fortune are to the poor. I Hope to see the fort of Arkansas tomorow and Hope to Leave the Boat I am now in if there is What the Kentuckians Term a "half Chance". Our Commanders Looks and acting are so strange that I have become quite Sickened-

the Weather quite rough, all day, cleared at night, the Flat Boats passed us this evening-We have made a bad Landing according to my Ideals-

\section{Sunday ioth December i 820}

We floated down to the Caledonian point or Petite Landing about 4 Mile above the real mouth of White River

here it was Concluded that Mr Aumack should walk to the old Post of Arkansas of course I \& Joseph prepared and having made Enquiries concerning the road we determined to go by Watter to the mouth of the Cut off and then walk the remainder; Anthony joined us, and the Skiff doubled oared was taken; We left at Io o'clock with Light hearts, Small Bottle of Whiskey a few Biscuits, and the determination of Reaching the Post that Night-

At the Entrance of White River we discovered that that stream Was full and Run Violently, the Watter a Dull Red Clay Color; We soon found ourselves forced to Land to Make a Natural Cordel of several Grape Vines and pull up by it - the distance to the Cutt 
off is Seven Miles that appeared at Least io to us: here We Met 2 Canoes of Indians from the Osage Nation, Landed our Skiff on the opposite side of White River Which we here found a beautifull Clear Stream and Backed by the Watters of Arkansas running through the Cut off; We Walked through a Narrow Path often so thickly beset with green Briars that We Would be forced to give back and go round-this followed through Cypress Swamps and round Pounds and Cane Breaks untill We reached the first Settlement owned by a Frenchman Called Monsr Duval. this friendly Man about going to bed offered us his assistance put on shoes \& clothing and Lead us 7 Miles through Mud \& Watter to the Post; and at 9 o'clock P. M. We Entered the Only Tavern in the CountryWearied, Muddy, Wet, \& hungry-the Supper Was soon calld for, and soon served, and to see 4 Wolfs taring an old Carcass would not give you a bad Idea of our Manners while helping Ourselves the Bright Staring Eyes of the Land Ladies Notwithstanding

however I found Mrs Montgomery a handsome Woman of good Manners and rather superior to those in her rank of Life-to Bed and to sleep sound was the next Wish for 32 Miles in such a Country May be Calculated as a full dose for any Pedestrian per day-Led into a Large Building that formerly perhaps saw the great Concils of Spanish Dons we saw 3 Beds containing 5 men, Yet, all was arrangd in a few moments and as 
the Breaches were Coming off our Legs, Mr Aumack \& Anthony slided by into one and Joseph \& myself into Another, to force Acquaintance with the strangers being of course necessary a Conversation ensued that Lulled Me a Sleep, and Nothing but the Want of Blankets Kept Me. from Resting Well, for I soon found a Place between the Tugs that Supported about io lbs of Wild Turkey Feathers to save (?), My roundest Parts from the Sharp Edges of An Homespun Bedstead-

The Morning broke and with it, Mirth all about us, the Cardinals, the Iowa Buntings, the Meadow Larks and Many Spcies of Sparrows, chearing the approach of a Benevolent sun Shining day-dressed and about to take a View of all things in this Place, Met a Mr Thomas known formerly when in the Paragon Steam Boat-he introduced Me generally to the Medley Circle, around, and from thence took Me to a Keel Boat to receive the Information I Wanted about the Upper Countries through Which this Noble Stream Meanders-think of My Surprise at seeing here a Man who 13 years ago gave me Letters of Introduction at Pittsburgh (Penn) for Men in Kentucky-this Was Mr. Barbour the former Partner of Cromwell-he Met Me with great Cordiality, told me of the absence of the Governor, the Indian agent and also that the Osage Missionaries had proceeded about I 50 miles up to a Place called the Rocky Point. 
the Cadsaw is [hi] beyond that where a New town, the seat of Governt was expected to be situated.

disapointed to the utmost in Not Meeting those who I supposed Would of Course give me the best Information I requested of $\mathrm{Mr}$ Thomas to give the Governor My Letters and beg of him to Write Me a few Lines at New Orleans to the Care of Governor Robertson[the Gentleman--] Mr Barbour told Me that he had for Several years past gone up to the Osage Nation about 900 Miles and that his Last Voyage he fell in with Nutall the Botanist and had him on board for 4 Months-that Many species of Birds were in that Country unknown in this and that the Navigation Was an agreable One, at the same time that it was rendered profitable by the enormous profits derived from the Trade with the Indians, whom he represented as friendly and Honorouble in all there dealings-that he would be extremely Happy of My Company and that of My Companions and that if I did not go with him at present that he Hoped I would Meet him when coming down the Arkansas Next Spring or Summer for he is about 6 Months employd each Voyage-The Post of Arkansas is Now a poor, Nearly deserted Village, it flourished in the time that the Spaniards \& French kept it, and One Ioo years passed it could have been called and agreable Small Town-at present, the decripid Visages of the Worn out Indian Traders and a few American famillies are all that 


\section{AUDUBON JOURNAL}

gives it Life, the Natural situation is a handsome One, on a high Bank formerly the Edge of a Prairie, but rendered extremely sickly by the Back Neighborhood of Many Overflowing Lakes \& Swamps.-

I was assured that only Two frosts had been felt here this Season and that the Ice in the River never Stopped the Navigation-

the Town now Prospering at Point Rock is high healthy and in the Center of a Rich tract of [Land] Wood \& Prairie Lands-and probably may flourishthe Arkansas River flows a Thick Gurrent of red Clay \& Sand, and if not for its coloring would have much of the appearance of the Mississippi-Cotton is raised here With some advantage-Corn grows Well, game \& Fish are plenty-

I here feel Inclined to tell you that an oportunit of Good; Fresh Flour Whiskey, Candles, Cheese, Apples, Porter, Gider, Butter Onions, Tow Linen and Blankets would meet with advantageous Sales during Winter, accompanied by Powder Lead, Flint, [and] Butchers Knives, Rifles, and blue Shrouds for the Indians.

After Breakfast We Left the Post of Arkansas with a Wish to see the Country above, and so Strong is My Anthusiasm to Enlarge the Ornithological Knowledge of My Country that I felt as if I wish Myself Rich again and thereby able to Leave My familly for a Couple of Years-here I saw a French Gentleman who but a few Weeks passed had Killed a Hawk of a Large size per- 


\section{A UDUBON JOURNAL}

fectly White except the Tail Which Was a bright red. Unfortunately, no remains of its Skin Legs or Bill were to be found-We travelled fast-reachd the Cutt off and Landd our Skiff, having Killed 5 Crows for their Quills, Never before did I see these Birds so easily approachd and in fact all the Birds We saw, 2 Hawks I did not know hovered high over us-the Indians still at their Canoes, We Hailed, and gave them a Drachem of Whiskey, and as they could not speak either french or English, I Drew a Deer with a stroke across its hind parts, [-] and thereby Made them Know our Wants of Venaison hams-

they brought 2 We gave them $50^{\text {cts }}$ and a Couple Loads of Gun Powder to each, brought out smiles, and a Cordial Shaking of Hands-a Squaw with them a Handsome Woman waded to us as Well as the Men and drank freely-[Never do I] Whenever I meet Indians I feel the greatness of our Creator in all its Splendor, for there I see the Man Naked from his Hand and yet free from Acquired Sorrow =

in White River We saw a great number of Geese Malards and Some Blue Cranes-also Two Large Flocks of these unknown Divers or Pelicans-

reached our Boats about 6 in the afternoon fatigued but Contented a good Supper, Merry Chat-and good Looks all round-Went to bed all Well-

before I leave the Trip to the Arkansas Post I think I will give you More of it-We saw there a Velocipede 
Judge how fast the Arts \& Sciences Improved in this Southwestern Country-I want also to tell you that the Squaw on White River While Wading out to us Craked a Large Louse taken from under her arm-

The Intrepid Hawks are extremely plenty along the Banks of the Mississipi where the feed aboundantly on the Swamp Sparrows as also on the Sturnus depradatorius; some of these are so strong and daring that they Will attack some Ducks on the Wing and often carry them off several hundreds of yards to the Sand Bars-

The Brown Eagles that were so plenty on the Ohio have entirely disapeared and nothing by White Headed Ones are to be seen-

The Lakes found in the Interior are stored with the finest of Fishes Such as Pikes, Salmons-Rock, Bass Sun Perches $\&^{c}$ and the bottom covered with Thousands of Muskle Shells and Perrywinkles of many species-those Latter of Course find their Way while the Spring floods are so so general-the Bottom of Most of these Lakes is firm and Level-

\section{Tuesday Decembr I $^{\text {th }}$ I 820}

This day $\mathrm{M}^{\mathrm{r}}$ Shaw and Anthony Walked off to the Post and We floated down to the Mouth of that River, this We reached and Landed. I was so fortunate as to Meet the Steam Boat the Maid of [New] Orleans on board of Which I put a Letter for My Dearest Friend My Wife-with orders to put it in the St. Louis Post 
Office-Saw to Day Many Crows Mergansers and Geese, some Dun Divers-and a Large flock of My unknown Divers-

the Blue Jeays are now \& then seen-the great Carolina Wrens are very Aboundant-but the Snow Birds have disappeared, the weather is so Warm that Buterflies, Bats, Bees, \& Many Insects are flying about us and at the Arkansa I was assured that they had had but Tro Light frosts-

Mr Shaw is Expected Tomorrow Night and perhaps Will Leave us here to Proceed up that River, for we are told the Orleans Market is Extremely dullKilled a Gull precisely Such as I shot at New Port Kentucky, rather Fatter

The Wild Geese we now Shoot have Eggs swollen to the size of $\mathrm{N}^{\circ} 3$ Britt Shots-

An Indian Chief at the Mouth of the Arkansas Killed Three Swans one of which I was told Measured 9 feet from Tip to Tip-Those Indians had Left when We arrived,-a View of Such Noble Specimen Would have been very agreable-

The Prairie Hawk that I see here is not the Marsh Hawk of Willson it is Much Less-Lighter Color, the Tip of the Wings Black and only One Large Bend of Dark ending the Tail-they fly Much Like the Night Hawk and Catch Small Birds on the Grass Without Stopping their course- 
Wednesday Decembr $13^{\text {th }}$ I 820

A Beautifull day, Walked up the Arkansas in Search of a Lake but the Cane so thick that we give it upKilled Two Geese. Mr Aumack Shot at a Prairie Hawk but did not Kill it-I wrote Governor Miller the Copy of which is here annexed-

To his Excellency Govr Miller of the ArkansasSir-having had the Honor to receive several letters of recommandation to your Excellency, from Gen ${ }^{l}$ Harrison, Gen ${ }^{l}$ Lyttle and other Gentlemen, I felicated myself with the pleasure of an Interview with you-I Reached the Post of Arkansas but was foiled by your absence; having only a few Moments to remain at that place I begged of $\mathrm{M}^{r}$ Thomas to present you the Letters I was the Bearer of-these I even was not able to seal-

My ardent Wish to Compleat a collection of drawings of the Birds of our Country, from Nature, all of Natural Size, begun about I5 years since, and to Acquire either by occular, or reliable observations of others the Knowledge of their Habits \& residence; makes me wish to travel as far at Least as the Osage Nations on the Arkansas as also along the Whole of our Frontiers-

Should your arduous avocations admit-I would Consider myself very Highly honored and under great obligations to receive from your Excellency a few lines 
of Information respecting the Time, the Manner of travelling and what might be necessary to render such a Journey fruitfull to my Views - as well as your Personal Information of the discoveries you have made in Ornithology, in that part of America-My Intention is to Visit the country around New Orleans as far East as the Florida Keys, then ascend Red River, and to go to the Hot Springs-thence across to the Arkansas and Come down [it] to its Mouth where on My return to Cincinnati at present My familly Residence - yet My Plans are alterable as advised by Gentlemen of more Experienced

Should your Excellency contemplate any expedition upon Your River and I was sufered to Join it, I would be anxious to Meet any Wishes my Humble talents Could afford at any time-

With Hopes that your [Excellency] will not be displeased at the liberty I have here taken

$$
\begin{gathered}
\text { I remain with high respect } \\
\text { Your V. H. St } \\
\text { J. J. A. }
\end{gathered}
$$

P. S. if agreeable please

Direct to Governor

Robertson

Saw some Turkey Buzzard

Some Merganzers and Sand Hill Cranes-

Malards-Crows-Some Buntings-

Winter Wrens-Meadow Larks-Partridges 
Red Winged Starlings-and a Vast Number of Swamp Sparrows in the High Mississipi grass Parokeets-Golden Crowned Wrens-

Mr Shaw \& Anthony [not] returned [yet] at eleven o'clock, but did not effect their Business, They returned in a canoe, 30 Miles down the Arkansas to the cut off through that about 6 (miles) down White River 7 and down the Mississipi 15-this makes $5^{8}$ and the Distance from Arkansas Post to the Mouth of that River is 6o-

about One Mile below the Mouth of Arkansas in a Thick patch of Cane are Two Women the remainder of a party of Wandering Vagarounds that about 2 years ago Left some part of the Eastern State to proceed to the Promised Land-these Two Wretches, Never Wash Comb or Scarcely clad themselves, and subsist from the Scant generosity of the Neighbours-Now and then doing a little Sawing and Washing-

\section{Thursday Decemb $14^{\text {th }}$ I 820}

After Long consideration, our Gentlemen determined to do Nothing, and [Left our Landin] We Cutt Loose about io this Morning, the Weather quite Warm, Distant frequent Clapps of Thunder announcing a change-it soon begain to Rain, the Fog raised and We Landed again about 2 o'clock-saw here 5 Ivory Bill Wood Peckers feeding on the Berries of Some 


\section{A UDUBON JOURNAL}

Creeper they were gentle-Keeping a Constant Cry of Pet Pet Pet-Killed a Crow on the Drift wood it was not untill then that I discovered that a Crow Killed by Mr Shaw while I was at the Arkansas was a Fish Crow-it rained all Night Watter raising fast-

\section{Friday Decembr I $^{\text {th }} 1820$}

Rainy \& Cold, floated about 6 Miles-at One o'clock the Steam Boat, James Ross passed us-in the afternoon I had the good fortune to Kill a Beautifull Marsh Hawk Falco Eulginosus feeding on a Swamp Sparrow that I saw him Catch-When I approach him before I Shot he saw me first and flew a few yards where he sat tearing at his prey untill death reached him-the Prairie Hawk seen Yesterday is entirely diferent, in Size, Color, \& Manner of flying and [h]as it is a Nondescript I Hope I may meet it again-Killed 4 Teals and 2 Geese-the Watter rose 20 Inches this day-

I have seen the Marsh Hawks about September flying down the Ohio River, and several times about that season I have seen flocks of them travelling high and southwesterly-finding them Now plenty on these Shores Where great deal of rich food is afforded them by the Numerous quantity of Swamp Sparrows the mildness of the Weather, no doubt assures them a good Winter Residence-

the One I Killed Was a Male, in good order, Weigh-

$$
78 \sim
$$


ing Only $\frac{3}{4} \mathrm{lb}-$ Measured I 8 Inches full Length, breadth $3 \frac{1}{2}$ feet-the Insides of the Mouth Black-

\section{Saturday December I $^{\text {th }}$ I 820}

the weather much the same, heard this Morning that the Ohio has raised Immensely-Spent the day Drawing my Hawk but so dark and disagreable that I could not finish it-having Landed for 3 or 4 hours at the Head of the Cypress Bend We floated but a Short Distance-

Vast Many Geese seen to day-Joseph Killed a Pewee fly catcher close by the Boat-the little fellow Was very active, and in very good order-a femelle-

this Evening about roo Pelicans were in view on a Sand Barr, and although I had no expectations of reaching them We put off in the Skiff, when about 300 yards off from them, they flew and I sent them My Ball, without effect-these are the first I have seen this Journey. I Hope I will have one to draw before I reach N. Orleans-

The generality of the geese We Kill are very poor -and scarcely fit to eat-the Steam Boat Govr Shelby pass $^{\mathrm{d}}$ us heavily Laden-

When I was trying to approach the Pelicans, they rose from their slumber one at a time, and Shook their Wings as if to try if able to fly in Case of need-the Nearer We Came the faster they gethered and walked off untill they all flew without uttering any Noise- 


\section{Sunday December $17^{\text {th }} 1820$}

Raining all day. I finished my Drawing-Landed at Pointe Chico a few Miles before this the Spanish Beard is seen-Pointe Chico is a handsome spot on this river that never overflows--and answers well for the Growth of Cotton Corn \& c-Peach \& Aple Trees flourish well here, but Sugar will not grow-

a Man of good Manner assured me that the Marsh Hawks were very plenty here all winter, but not to be seen in Summer-and that the Pelicans disapear at this season for the South and return early in April with young-Many Red Winged Starlings-and Many Bleu Birds these were pleasing to me, the poorest note of these is allways wellcome to Mine ears-

the Watter raising very fast-

Last Night $\mathrm{M}^{\mathrm{r}}$ Aumack who was rather MerryWent to Shoot a Pelican about io o'clock P. M. to Cool himself returnd ${ }^{\mathrm{d}}$ without a Shot-

Saw Winter Wrens and a beautifull plant in full Bloom-Ivory Billed Wood Peckers becoming more plenty-

\section{Monday $\operatorname{Dec}^{\text {r }}$ I $^{\text {th }}$ I 820}

Raining all day, floated but a few Miles-Landed at a Place where Geese \& Ducks abounded-Killed a Crow, a Great Horned Owl, and a Winter Falcon. 


\section{Tuesday Decembr $19^{\text {th }}$ I 820}

Rain and fog all day-Landed within 7 Miles of Last Nights-Killed a Carrion Crow, a Winter Wren and I6 Parokeets, I heard and saw once a Thrush unknown to me but could not get a Shot at it-Immense flocks of Parokeets and Swamp Blackbirds-the Carrion Crow I shot at Would Not suffer us to go near than about Ioo yards and forced me to draw My Shot and Put in a Ball this brought him down Lifeless-

This Morning I Shot at a Bird unknown to Me and no doubt a Non Descript-it was of the Sparrow Genus-

Saw several Thrushes, very Shy. they sung Sweetly and also Constantly. Took for the Golden Crown ${ }^{d}$ Thrush Turdus Auracapillus; Also a French Mocking Bird Turdus Rufus - the Trees in Many places in the Thick Canes full of Leaves-and during this Rainy Spell the Weather as felt Much Like the Beginning of May-

\section{WednesDay Decembr $20^{\text {th }}$ I 820}

The Weather as desagreable as one could wish itRaining and so foggy that we could not see 5 o yards -drawing all day-in the Morning the Winter Wren Sylvia troglodites and afterwards the Carrion Crow, Vultur Atratus-at Twelve o'clock a Short Clearing taking place We floated about 4 Miles and Landed opposite side of the River-Cape Cummings Shot at an Ivory 
Billed Wood Pecker Picus Principallis broke his Wing and When he Went to take it up it Jump up and claimed a tree, as fast as a Squirel to the Very Top, he gave it up having but a few Loads of Shot-Joseph Came and saw it-Shot at it and brought him down-

We Boiled io Parokeets to night for Dash who has had ro Welps-purposely to try the effect of the Poisoning effect of their hearts on animals. Yesterday We Were told that 7 Cats had been Killed Last Summer by Eating as Many Parokeets-Killed Two Geese-Several Boats Landed along us to night

\section{Thursday Decembr $2 \mathrm{I}^{\text {th }}$ I 820}

We at last had fine weather, floated about 35 miles this brought us to the upper Part of Stack Island Now only a Barr the former having being sunk by the Earthquakes-Drawing nearly all day I finished the Carion Crow, it stunk so intolerably, and Looked so disgusting that I was very glad when I through it over Board-

Saw in the afternoon a Black Hawk, a flock of Pelicans at which I shot at about 200 yards as near as I could approach, Without effect. the Sand Barr where they were was Literally covered with excrements and their Feathers. Vast Many Geese seen all day, these Birds Now Pairing. Spanish Moss very aboundant on all the Cypress trees-Large flocks of American Teals and the constant Cry of Ivory Billed 


\section{A UDUBON JOURNAL}

Wood Peckers about us-scarcely any other except a few Peleated \& Golden Wings-have not seen a red head Wood Pecker for some time-the Carolina Wrens and Cardinals exercising their Vocal powers all day-

We received the visits of 2 Men, Wood Cutters from the Shore-they assured me that Pelicans were here at all seasons but that when the Weather is bad they keep in the Lakes in Great Flocks along with the Geese, Swans, Ducks, Cranes-and there find an aboundance of food-they spoke of a Black Hawk that Lives on Fish but I could not ascertain Much about size of anything else concerning it-

they reported that a few Weeks passed a Youth of about 12 Years having Met a Large Brown Tiger, or Cougar called here a Painter was so frightened that he died after reaching his Parents' house-those animals are now scarce, but Dear, Bears and Wolfs are plenty -Anxious to Know if Alligators were seen during this season, they answered in the affirmative. They could be seen every few days-some Keeping in Small ponds too Shallow to cover their backs and there Catch the Garr Fishes, root for frogs \& $\&^{c}$ that one Killed Lately had a Large Quantity of Black Walnut and Hickorys -they are Killed here for the Skin, that when tanned gives a fine Leather preserving the Lozanges of the Scales. One of the men said he owed them a Grudge for Killing An Excellent hunting Dog-while following a wounded Deer across a Lake, and that he re- 


\section{AUDUBON JOURNAL}

taliats on the Whole Species Whenever an opportunity offers-a Boy told us that one that had dugged a hole about 20 feet under the ground to resort to, in bad weather, was taken a few days ago; the earth having fallen on him during a heavy Dash of rain - they are easily Killed with a Clubb-the usual way of destroying them-they Move slow on the ground-but swiftly in the Watter-this is all hear say and put it here to Compare it with My Own future Observations

\section{FridaY December $22^{\mathrm{d}}$ I 820}

Started at 5 o'clock this Morning, and certainly deserves Noting-after breakfast Joseph \& I push off as usual in the Skiff in which we remained untill near Sun Down-Saw Three Black Hawks, Shot at this Twice, but these Birds are So Shy that I dared not advance nearer than Rifle Shot and Missed themWent to a house, to Warm our fingers, the wind blowing rather Sharp this morning-found a Handsome familly of Young Brats who as well as their Mamma Looked Clean and healthy-here We saw the Pameta Plants along the Fences-

in the afternoon the sun Shown Warm, the Geese where in Thousands on the Willow Bar, fighting and Mating. Malards, Teals and Wood Ducks aboundant -Killed One Malard and Two Wood Ducks-saw One Swan-One Redtailed Hawk, several Sparrow Hawk-Many Crested Titmouse-Autumnal War- 
blers all through the Shaggy Beards-The Carrion Crow plenty, and their relation the Buzzard.

the Pewee Fly Catchers very busy diving at Insects and Singing Merely-saw several Bald Eagles that I Might have Shot at-

a little before Sun down a Steam Boat Called the Mars passed us, a poor running Machine-apparently an Old Barge-

Our Commanders spoke of Cutting a Stick at I2 o'clock, but the Axes were dull and We did not get up untill 3.-

\section{Saturday Decembr $23^{\text {d }}$ 820}

the Moon shining beautifully Clear, the Weather, calm a heavy White frost-started at 3 o'clock-

as soon as the fog disapeared, J. \& I putt off for the Mouth of the Yazoo River, seeing some Geese Made for them and Killed One-in the Mouth of that River I perceived a Large flock of My unknown Blackbirds that I suppose Brown Pelicans-Landed below them, and after crawling on My belly for about 300 yards I arrived within about 45 yards I fired at 3 that were perched Close together on a dead Stick about 7 feet above the Watter, at my shot they all fell as so many stones. I expected them to be all dead but to My surprise, those and about 20 swimming under them had dove, they soon rose and took Wing after running on the Watter about $5^{0} \mathrm{Y}^{d s}$ at the exception of the 


\section{A UDUBON JOURNAL}

One I had taken aim on-it would not raise, the Skiff brought up We rowed after it, diving below us up the Yazoo Nearly one Mile, Yet I could not give it up, it became Warier, \& remained Less under Watter the Nearer We approach when at Last Joseph Shot at its head [the] \& Neck (the only part in view Looking much Like a Snake) and Keeled it over-I took it up with great pleasure and anxiety-but I could Not ascertain its Genus-for I could not Make it an [d] Albatros the only Bird I can discover any relation to-

We had to exert ourselves to reach our Boats-this done, I began Drawing-We passed to day the Walnut Hills a handsome situation on the Mississipi covered with Cotton plantations-We also passed the Small Village of Warren commonly Called "Warington" opposite this place (Not Improving) Met the St. Elca S.-B.

The Yazoo River flowed a Beautifull Stream of transparent Watter, Covered with Iooo ${ }^{\text {ds }}$ of Geese \& Ducks and filled With Fish-the Entrance Low Willows \& Cotton Trees-We run to day 49 Miles-the Weather rather too Warm-

Monday December $25^{\text {th }}$ I 820 Chrismas day

We passed, the Petit Gulf-early this morningthe Steam Boat Comet passed by from Louisville 9 Days-

I had the pleasure of seeing Mr Aumack Killed a $86 \cdots$ 


\section{A UDUBON JOURNAL}

Great Footed Hawk, the Bird Alexander Willson heard so Many wonderfull Tales of-these Birds are plenty on this River at this season every Year according to all the accounts I have Collected but allways extremely Shy, and I Believe few Men Can Boast of having Killed Many of them, for I 5 years, that I have hunted and seen probably one hundred [of] I Never had the satisfaction of bringing one to the GroundI often have seen them after hearing their Canon Ball Like wissling Noise through the Air seize their Prey on the Wing particularly at Henderson Kentucky, where I watched for Weeks near a Pigeon House, that furnished one of those daring Robbers, with food \& Exercise-No doubt that the Clouds Ducks of some many Species as are found on this River, renders it a pleasant and fruitfull Winter Residence-

We have seen about 50 since a few Weeks-they fly fast, with quick motions of their Wings, seldom Sailing except when about alighting:- the Specimen before me is a very Old Bird and a beautifull one, When on the Wing they appear Black and are often Mistaken for the Falco Niger-Killed 3 Geese;-

Saw a Tell Tale Godwit, the Only one seen since I Left the Ohio-but understanding that that River is now considerably raised, I expect they are forced to abandon it-

Cape Cummings saw 4 Deer this Evening-

We are Now Landed about I 5 Miles above Natchez, 
and if No head Wind takes place Must reach that City To morrow

I Hope that My Familly wishes me as good a Christmas as I do them-Could I have spent it with My Beloved Wife \& Children, the exchange of situation would have been most Agreable-I hope to have some tidings of them Tomorrow $=$ the Shores are now Lined with Green Willows the Weather much Like May-at Henderson-The Thermometer is allmost every day from 60 to $65-$

\section{Tuesday Decemb ${ }^{26^{\text {th }}}$ I 820}

Beautifull Morning, Light frost-I began my drawing as soon as I could see-drawing all day-

We saw to day probably Millions of those Irish Geese or Cormorants, flying Southwest - they flew in Single Lines for several Hours extremely high-

At half Past I I o'clock The Boats Landed at the Natchez Bluffs amongst about Ioo More, several S.B. ${ }^{t s}$ were also at this place $=$ the Carrion Crows first attracted my Attention, hundreds of them flying constantly Low over the Shores and alighting on the Houses-

I Rec ${ }^{d}$ Two Letters from my Beloved Wife, dated $7^{\text {th }} \& I 4^{\text {th }}$ of Nov $^{r}$ the Last date contained one from My Brother G. Loyen Dupuygandeau dated July 241820 So Busy I have been all day drawing, that I did not even go to the Shore-a Little before Dusk I saw from 
our Boat Roof the Magnolia \& Pines that ornement the Hills above this Place-

I Wrote a Long Letter to My Lucy with Hopes that it would be in time for the Mail of Tomorrow-

Our Commanders and Mr Shaw found every article of Produce Low, perhaps too Low to resound themselves-

I found the Stomack of the Great footed Hawk filled With Bones, feathers, and the Gizzard of a Teal, also the Eyes of a Fish and Many Scales-it was a femelle Egg numerous and 4 of them the size of Green Peas-

As we approach Natchez I [saw] remarked in several places-Saw Mills, placed over ditches cut from the River and running to the Swamps which in time of floods afford a Good Current-these ditches also serve to furnish the Mills with timbers floated through them from the Interior $=$

We have also seen very Large Rafts of Long Logs Intended for Mr Livingston's Warf at New Orleans -a Rafter assured us of having $\mathrm{rec}^{\mathrm{d}} 6000 \$$ for the Last Parcel he stole rom the Government's Land-

\section{Wednesday Decembr $27^{\text {th }}$ I 820}

As soon as my drawing was finished, I cleaned and Went to Natchez properly speaking-there to my uttmost surprise I met Nicholas Berthoud, who accosted Me Kindly, and ask ${ }^{\mathrm{d}}$ me to go to New Orleans in his Boat-I accepted his offer- 
from the River opposite Natchez, that place presents a Most Romantick scenery, the Shore Lined by Steam vessels [and f] Barges \& flat Boats, seconded by the Lower town, consisting of Ware Houses, Grogg, Chops, Decayed Boats proper for the uses of Washer Women, and the sidling Road raising along the Caving Hills [about 20o] on an [Inclinat] oblique of a quarter of a Mile and about 200 feet High covered with Goats feeding peaceally on its declivities, while hundreds of Carts, Horses and foot travellers are constantly, meeting and Crossing each Other reduced to Miniature by the distance renders the whole really picturesque [the Carrion Crows Looking on the Whole with Wistfull Eye]; on the Top of this the Traveller comes in sight of the town as he enters [and] avenues of regularly planted Trees Leading to the diferent Streets running at right Angles towards the River; on the left the Theater a poor framed Building and a New and Elegant Mansion the property of $\mathrm{M}^{\mathrm{r}}$ Postlewait attract the Anxious eye--on the right the rollings of the hearth [and left in the St] thinly diversified by poor habitations soon close the prospect-advancing, [Two feet] he is Led into Main Street; this as well as the generality of the place [is] too Narrow to be Handsome, is rendered Less Interesting by the poorness \& Iregularity of the Houses, few [Built] of which are Bricks-and at this season very much encumbered by Bales of Cotton - the Jail, Court House are New and tolerable in their

$$
90-
$$


form the Lower part of the former [is] a Boarding House of some Note. there are Two Miserable Looking Churches; [and already the] I dare not say unattended but [I] think so-

the Natchez's Hotel is a good House built on the Spanish plan, i.e. with Large Piazas and Many Doors and Windows-Well Kept by $\mathrm{Mr}^{\mathrm{r}}$ John Garnier and is the rendez vous of all Gentile Travellers and Boarders - Several Large tavern which I did not Visit furnish Amply the Wants of the Strangers that at all times abound from [all] different parts of the Union-this place now Contain about 2000-inhabitants and Houses, has a Bank in good Credit-a Post Office receiving the Diferent Mails Thrice per Week, a Public reading Room and 2 printing offices-

the Naturalist will immediatly remark the general Mildness of the temperature on seeing at this season the [Vegitation in] premature Growth of Lettuces, Radishes and other vegetables that in our Eastern Latitudes are Carefully nursed in April and sometimes in May-

the Pewee fly Gatcher, the Notable Mocking Bird, constant residents [often] assure him that if frosts are few they must be of short duration, and the Numberless prostrated Carrion Crows in the less frequented Streets [and Yards] prove to him the unhalhiness of the atmosphere--those certainly may be considered as necessary Evils, for no Birds are more disagreable at 
the same time that few are More Valuable in Climates Like this-

I saw here a Gentleman with Whom I travelled some distance down the Mississipi My first Voyage but as he did not or Would Not recognize my features I spoke not to him-

the Country back of Natchez was represented as Good and fitted by rich planters who once raised a Large [annual] quantity of Cotton the principal article of Export-Opposite this the Lands are extremely Low and overflow to a great Extent and Depth the Mail in Times of flood goes by Watter through the Woods nearly 40 Miles Toward Natchitoches on Red River.

Indians are Daily seen here with diferent sorts of of Game-for which they receive high Prices, I saw Small Wild Turkey sold by them for One Dollar each, Malards at $50^{\text {cts }}$

Although the Weather is Comparatively Mild, the Orange trees will not bear the Winters in open air = and sometimes the frosts for a day or two are severely felt-the remains of an Ancient Spanish fort are perceivable, the Center is now Honored by the Gallows and the Ditch serves as buriing ground for Slavesthe Cemetiere Lies at the extremity of the Townabout 2 Years ago a Large part of the Hill gave Way, Sunk probably $5^{\circ}$ feet and Carried Many Houses into the River - this was occasioned by the quick Sand 


\section{A UDUBON JOURNAL}

Running Springs that flows into the Strata of Clay and pebles of Which the Hill is Composed-

this sunken part is Now used as the depot of Dead Carcasses, and often times during the Summer emits such Exalaisons as attract hundreds, Nay I was told Thousands of Carrion Crows =an Engine is now Nearly in Operation Intended to raise the Watter of one of the springs or ecoulement or drains to suply the City-This indeed is much wanted, Watter hauled from the River is sold at $5^{0^{\text {cts }}} \mathrm{p}^{\mathrm{r}}$ Barrel [and] taken out of the Eddy very impure= I found few Men Interested towards Ornithology except those who had heard or pleased to Invent Wonderfull Stories respecting a few Species-

$\mathrm{Mr}$ Garnier on whom I can rely told me that he had given Liberty to a Mocking Bird after several Years confinement and that for several Years afterward the Bird came daily in the House as if to thank him for his Generosity and Past Kind Attentions= $\mathrm{M}^{\mathrm{r}}$ James Willkins to whom A. Willson had Letters of Introduction assured me that his Work was far from Completed, that through his Mere transient observations he had discovered several New Specimens but being a Man of Business he Never had Noted any

a Bird Much resembling the femelle humming Bird is often seen (it is said) during Summer, feeding by Suction amongst the Magnolias She is about Twice the Size of a Wren- 


\section{A UDUBON JOURNAL}

The Carrion Crows Never breed in or Near the Town-having Not one Cent when I Landed here I imediatly Looked for something to do in the Likeness Way for our Support ([for] unfortunately Naturalists are Obliged to eat and have some sort of Garb) I entered the room of a Portrait Painter Naming himself Cook but I assure you he was scarcely fit for a Scullion, Yet the Gentleman had some politeness and procured me the drawing of two Sketches for $5 \$$ each, this was fine sauce to our empty stomacks

One was imediately paid for, the other a very excellent resemblance of $\mathrm{M}^{\mathrm{r}}$ Mathewson probably never will be, for that Gentleman absented the same Evening and never Left orders to any body to pay-I merely put this down to give you the Best advice a Father Can present you with. Never to Sell or Buy without imediately paying for the same-a constant adherence of this Maxim will Keep your Mind and person all times free, \& Happy

Mr Cook much pleased with My Drawings and quickness of performance, desired to travel with us if suitable Mutual arrangements could be Made. I Asked him to pay me Two Dollars per day Monthly in advance and furnish besides, One Third of the Whole Expenses, [furnishing] providing himself with Whatever Materials might be necessary-

He spoke of Joining us in a Couple of Weeks; I thought it very uncertain-the awkwardness I felt 
when I sat to Dinner at the Hotel was really justified to me; having not used a fork and Scarcely even a Plate since I left Louisville, I involuntarily took Meet and Vegetables with My fingers several times; on Board the flat Boats We seldom eat together and very often the hungry Cooked, this I perform ${ }^{\mathrm{d}}$ [often] when in need by Plucking \& Cleaning a Duck, or a Partridge and throwing it on the Hot embers; few Men have eat a Teal with better appetite than I have dressed in this manner-

Others prefering Bacon would Cut a Slice from the Side that hung by the Chimney and Chew that raw with a hard Biscuit-Such Life is well intended to drill men Gradually to hardships to go to Sleep with Wet Muddy Clothing on a Buffalo skin stretch on a Board-to hunt through Woods filled with fallen trees, Entengled with Vines, Briars, Canes, high Rushes and at the same time giving under foot; produces heavy sweats [and] strong Appetite, \& Keeps the Imagination free from Worldly thoughts, [and] I Would advise Many Citisens particularly our Eastern Dandys to try the experiment-leaving their high heeled Boots, but not their Corsets, for, this would no doubt [would] be Serviceable whenever food giving way, they might wish to depress their stomacks for the occasion- 


\section{A UDUBON JOURNAL}

\section{Thursday December $2^{\text {th }}$ I 820}

Weather sultry. Saw some Mocking Birds and was assured that they remained during the Winter here-

Nicholas having invited me to stay at his Lodgings I Breakfasted at the Hotel of $\mathrm{M}^{\mathrm{r}}$ Garnier a French Gentleman of Agreable Manners who kindly procured me Willson's Ornithology from $\mathrm{M}^{\mathrm{r}}$ James Wilkins to whom I was introduced to by Nicholas.

\section{Friday December $29^{\text {th }}$ I 820}

The weather this Morning had taken a remarquable Change, the Thermometer had fallen from 72 to $36-$ it snowed and blew hard from the Northwest-Last night the Musquitoes, were quite troublesome

I made Two Sketches to day for $5 \$$ each; after Many Inquiries for the $9^{\text {th }}$ Volume of Willson I was disapointed in my wish of examining it none of the subscribers have $\mathrm{rec}^{\mathrm{d}}$ it-

Joseph and Cape Cummings still remaining on Board of Mr Aumack's Boat-I had the satisfaction of ransacking the Fables of Lafontaine, with Engravings -Wrote to Dr. Drake and Mr. Robt Best-

\section{Saturday Decembr $30^{\text {th }}$ I 820}

the Weather very Cold, the Thermometer a 25Spent all day Writting the Name and Such De$9^{6}-$ 
scriptions of the Watter [s] Birds in Willson as would enable me to Judge whenever a New Specimen falls my Praise-

Mr Aumack Left this Morning in our Boat taking with him Cape Cummings-I felt Sorry at parting With that really agreable Compagnion [and the More so When I thought that Like Me he had to meet all the -.] I Wrote to My Beloved Wife-

\section{Sunday Decembr $3^{\text {th }}$ i 820}

Early this Morning We prepared for our Departure, our things were Collected, and Carried to the Keel Boat-however it Was not untill One o'clock that the Steam Boat Columbus hauled off the Landing-

We Made fast to her Stern with Two Ropes and went very Swiftly the Moment She was under full headway-

I drew this afternoon-and here I have to tell a sad Misfortune that took place this Morning-having Carried under My Arm My Smallest Port Folio and Some other articles I Laid the Whole on the Ground and ordered Mr Berthow's Servant to take them on Board

I unfortunately Went off to Natchez again to breakfast the Servant forgot My Folio on the Shore and Now I am Without, any Silver paper, to preserve my Drawings, have Lost some very Valuable Drawings, and My Beloved Wife's Likeness = the greatest Exer- 
cions I now Must Make to try to find it again, but so dull do I feel about it that I am nearly Made Sick

I Wrote to $\mathrm{M}^{\mathrm{r}}$ John Garnier, requesting him to advertise and procure some one to try to find $\mathrm{My}$ Port Folio [for] but no Hopes can I have of ever seeing it when Lost amongst I50 or I6o flat Boats and Houses filled with the Lowest of Caracters-No doubt My Drawings will serve to ornement their Parlours or will be Nailed on Some of The Steering Oars-

We passed to day A Long Line of Bluffs exquisiting grand to the sight-

My Port Folio Contained I5 Drawings Three of Which were Non Descripts-One a Duck extremely Curious and rare that I had Named the Fintail: Should I not get it again, it may retard My return home very Considerable-

\section{Monday January ist ${ }^{\text {st }} 82$ I}

This day 2 I Years since I was at Rochefort in France. I spent most of that day at Copying Letters of My Father to the Minister of the Navy-

What I have seen, and felt since, would fill a Large Volume - the Whole of Which Would end at this Day January I $^{\text {st }}$ I82I. I am on Board a Keel Boat going down to New Orleans the poorest Man on it-\& What I have seen and felt has brought some very dearly purchased Experience, and Yet Yesterday I forgot that No serv- 
ant could do for Me What I might do Myself; had I acted accordingly; My Port Folio Would now have been safe in my possession-

Not Willing to dwell on Ideal futurity, I do not at present attempt to forsee where My Poor Body may be this day 2 Months

at 12 o'clock to day the Columbus Came too at Bayou Sarah - a Small Village at the Mouth of that Inlet-Many flat Boats the Steam Boat and 2 Briggs waiting for Cotton-the Steam Boat Alabama put off as we came to, and about half an hour after; the Columbus Left us to ourselves to try to reach Baton Rouge before her, to procure the freight there-promissing to wait 3 hours.

The Lands are flatening fast - the Orange trees are now and then seen near the Rich Planter's habitation -and the Verdure along all the shore is very Luxuriant and agreeable-the Thermometer at-68 at 12 o'clock in the Shade, the Day Beautifully fair-Expected to see some Alligators = Many Irish Geese in the Eddys-Malards but few geese $=$ at half past 6 o'clock P.M. we came opposite Baton Rouge but the Steam Boat had left and of Course we proceeded on our Way floating-this Last place is a Thrifty Villege on the New Orleans State-from some distance above Levees have made their appearance-I saw a Negro Man fishing by deeping a Scoup Net [constantly] every moment in the Watter immediately at a point Where 


\section{A UDUBON JOURNAL}

the current ran swift forming an eddy below, he had taken several tolerably Large Cat Fishes-

\section{TuesDay January $2^{\mathrm{d}}$ I 82 I}

We floated all night without accidents, the river since Natchez is much deeper, and free of Sawers and Snaggs - at day breake found ourselves about 50 Miles below Baton Rouge; the day Cloudy, raw, and some Wind a head-

the Plantations increase in number, and the Shores have Much the Appearance of those on Some of the Large rivers of France, their Lowness Excepted, the points are quite diferent to those on the River above, One May see the River below them by Looking across in Many places-and from the Boat we can only have a View of the upper windows, Roofs and Tops of the Trees about them. the Whole is backed by a dark Curtain of Thickly Moss covered Cypresses-flat Boats are Landed at nearly every Plantation, this being a Sure method of disposing of their produce to a better profit, travellers on horse Back or Gigg go by us full Gallop as if their Life depended on the accelerity of their movements-I have Seen More Common Crows since Natchez than I ever saw in My Whole Life before, the Shores and Trees are Covered with them but yet very few fish Crows have been Seen-saw some Pelicans, Many Gulls, Buzzards \& C. Grows- 
our Situation in this Boat is quite ComfortableWe have a good Servant to wait on us, are served with regular Meals, Glean and in Plates-Move much faster than With Mess ${ }^{\text {rs }}$ Aumack \& Lovelace, having here 8 Roaers who dare not contradict orders-

it rained and blowed hard a head, about One Mile below Bayou Lafourche. We Came to-the weather did not stop Joseph and Myself from taking a walk to the Swamp back of Plantation in front of which the Boat was moored-after Chasing the Note of What I supposed a New Bird for a considerable time, I found the deceiving Mocking Bird close by me and Exulting with the Towe Bunting's cheep-Joseph was more fortunate he Killed Two Warblers, one the Red Poll (of this We saw about a dozen) the other I have Not yet ascertained-although in Beautiful plumage; Both Male-how Sweet for me to find Myself the $\mathrm{I}^{\text {st }}$ of January in a Country where the woods are filled with Warblers, Thrushes, and at the same time see the Rivers and Lakes covered with all Kinds of Watter Birds-

the Pewees are quite gaily, I have seen this day 3 Cat Birds-if this is not the winter retreat of all our Summer Birds it is at all Events that of very manyhow happy would I feel to see some future January surrounded by the diferent species of Swallows Skeeping about, with the Whippoorwill \& Night Hawk

-I drew the Likeness of $\mathrm{M}^{\mathrm{r}}$ Dickerson the Master 


\section{AUDUBON JOURNAL}

of the Boat-he paid me in Gold-took the Outlines of Both the Warblers by Candle Light to afford Me time to morow to finish both-

\section{$-3^{\mathrm{d}}-$}

Raining \& Blowing hard all Night the weather cooled Considerably. much Like some of our April day at Henderson-took a Walk Early, while waiting for the Light to Increase and enable Me to Work-passed through a Large Cotton Plantation yet unpicked Looked Like if a Heavy Snow had fell and frose on every Pod-

the great regularity with which this is [Planted] sowed and raised attracts the Eye imediatly; it Lays in rows I believe allways runing at right Angle to the River, about 6 feet distant from each other and the plants about 3 and so straight that your Eye is Carried to the farthest extremity of the field without the Lease obstruction-even at this time that the Cotton has Ceased to be attended for Many weeks, it is quite free from Weeds of any sort-

the Woods here have a new and very romantic appearance-the Plant Called Pamitta raises promiscuously through them the Moss on every tree darkens the under growth and affords to the [Mind] melancholy [fashioned] Mind a retreat thooted by the Chirpings of hundreds of [-] Beautifully Plumed inhabitants- 


\section{A UDUBON JOURNAL}

the flocks of Blackbirds taking the Species En Masse, feel the air, they pass Southwest constantly; forming a Line Like disbanded Soldiers all anxious to reach the point of destination each hurring to pass the companion before him-

Doves are plenty, the Cardinal Gros Beaks very numerous and all Species of Sparrow inabiting the Interior are here-I remark ${ }^{d}$ great Many Brown Larks busy feeding on the Drift Wood that feels Many Eddys-

I drew both My Birds, the first on a plant in full bloom that I plucked Near the Boat-saw about 50 Mocking Birds some of them extremely Gentle, and holding their tail Leaning back allmost over their Heads-

We were Visited by several french Creoles this is a Breed of animals that Neither speak French English nor Spanish correctly but have a Jargon composed of the Impure parts of these three-

they Stared at My Drawing, and when a litle Composed Gazed and Complimented Me very Highlyon asking them the names of about a dozen diferent Birds then lying on the Table they Made at once and without hesitating a Solid Mass of Yellow Birds of the Whole-One of them a young Man told Me that he could procure 3 or 4 dozen of them every Night by hunting the Orange trees with a Lantern-I can said he "see the Rascalls White belies and Knok them 


\section{AUDUBON JOURNAL}

down with a Stick very handy"-few of these good Natured Souls could answer any valuable account of the Country-

Some toads were hoping about this evening, and on turning a Dead Tree over, we found several Lizards, who moved with great Vigour-at Sunset the Wind Lulled, the Captain, Sailors and passingers all anxious to reach New Orleans, it was determined that after a that after a good supper the oars would be used untill day break tomorow, if so We May see the City early

I Shot this Evening at a Sparrow Hawk that being badly Wounded sailed directly for a hole (probably that a Wood pecker) and [escaped us] no doubt died there- $\mathrm{a}$ few moments previous he Was teazing an American Buzzard-

Joseph Killed One Teal-with several Goldfinches and Warblers, some Sparrows, but Nothing New-

\section{Thursday January $4^{\text {th }}$ I 82 I}

at 4 o'clock this morning the wind was so high, that it forced us to Come to a litle above Bonne Care's Church-the weather was rather cold, as soon as day broke walkd over to the Swamp

Saw some Birds that I took for Large non described Cukoos as they flew high over us, they had a new Note to me-Many Warblers, Robins, blue Birds, Cardinals, 
Grakles, Sparows Goldfinches, doves, Golden Wing Woodpeckers, One Red headed one, Many, Carolina \& Winter Wrens-Sparrow Hawks, and a Large one unknown, on our return to the boat we Started with Hopes that We could make some headway-but were forced to about a Mile below the Church-I paid my Respects to the Pastor, to make some Inquiries respecting Mr Lecorgne, George Crogham, and the country; but I found only a tall thin dirty Creole who could not say much besides the prayer for the prosperity of the Brick Church now erecting-from this pennsionary of Bigots I went to a School House; there I had the pleasure of meeting an Old, Polite, and well Instructed French Gentleman in charge of about a dozen of Pupils of Both Sexes-he told me that George Crogham resided about 3 Miles from this Place across the Mississipi, that he was not acquainted with Lecorgne's name-that this Country was a fine field for my Wishes; [he] walked to the Boats, examined attentively My Drawings and told Me that having Left Europe and the World of Talents for so many Years such a Sight was very gratifying-We hunted again and Saw more of the Cuckoos these [by] this time I saw on the Ground and Knew them at once for some of the same Birds I had Shot my preceeding Voyage and had taken for Boat Tailed Grakles-I Killed 3, Two femelles and one Male and had the pleasure of examinng their Manners very Closely-their Voice is 
Loud and Sweet and their Movements elegantly airy -a Beautifull male was very busily Engage in carying some straws to a Large Live Oak, but loosing the Bird every time through the Spanish Moss, I Could Not see any appearance of Nest, and so early in the season could not presume it was for the purpose of building one-I Shot him-and Joseph Killed another femelle-these Birds are considerably More Shy than any other Grakle-fly very Loosely when in flocks, uttering constantly a Chuck [very] diferent to that of the purple Grakle-Gracula quiscula-and their flight resembles that of our Cuckoos and that of the Cukoo of Europe-While on the ground their walk is Elegant and Stately carrying their Long concave tails rather high-feed Closer to each other than Swamp Black Birds: Turton speaks of their Shortish Bills and gives for total length 13 Inches-this was taken no doubt from a Young femelle-the Male now before me Measures $15 \frac{3}{4}$ Inches-my drawing Shews you Male \& femelle, and tomorow it being finished I will give you a description - the French here call them starlings but on all questions respecting them or any other birds their answer is a constant Oh Oui-the country is here richly adorned by handsome dwelling Houses, Many Sugar and Cotton Plantations running about One Mile and half to the Swamp, free from Old trees and Stumps-every house a L'Espagnole-orange trees, now hanging with their golden fruits forming avenues 


\section{A UDUBON JOURNAL}

and Edges-the fields Well fenced in and dreaned by ditches running to the Swamps-

the Mocking Birds are so Gentle that I followed one along a fence this morning for nearly one Mile Keeping only one panel between us the whole of the distance-I have Not heard one sing yet; but imitating Many Birds-

about 5 o'clock we again ventured off and again the Wind drove us in Shore and now we are Landed on a point where our Boat rolls merily-raining hard -thermometer to day at 52-this morning the french Gentlemen Wrapd up in their Cloaks Kept their Handerkerchiefs to their Noses-What would become of them on the Rocky Mountains at this Season-our Captain Exchanged some Apples for Oranges receiving 2 for $\mathrm{I}-$

\section{FRIDAY January $5^{\text {th }}$ I 82 I}

We had some Light Snow this morning, drawing nearly all day, the wind blowing violently-Shortly after Breakfast I saw some Terns Winowing in the Eddy below us. Killed Two on the Wing-on the Falling of the first, the Second approach ${ }^{d}$ as if to see What was the Matter. I shot it dead, when the remaining Two that where coming fast wheeled and flew out of our Sight imediatly-these Birds flew Lightly with their Bills perpendicular over the Watter on which they appeared to Keep a close attention, Now \& then fall- 
ing to it and taking up Small fragments of Buiscuits thrown from our Boat-I finished my Gracula Barita but not the drawing; the rocking of the Boat quite disagreable-took a Long Walk towards Evening, saw Many Warblers particularly the Maryland Yellow throat. Shot an Hermit Thrush; paid a Visit to a Cottager a French Creole, handsome Children who were all afraid of me-the Lady remarkably handsome their Little Garden was adorned with a few orange Trees some fine Lettuces filled the Borders; Gren Peas nearly in bloom, Artichaux, reminding me of the Happy days spent in France-bought some delightfull radishes, and Enquired of Birds of Course; One League distant is a fine Lake, now the rendez vous of Ducks, Geese, $\&$ c but could not obtain Valuable remarks-the transient Cool Weather as rendered the Mocking Birds so gentle that they Scarcely would move out of the Wayat Night I drew the Outline of the Tern I had shot and ransacked Turton's but all without effect. Yet I do not Consider this as a New Speci[men], untill I See Willson's $9^{\text {th }}$ Volume-the Gracule Male I draw Measured in Breadth 22 Inches-Tongue bifid-and I found to day that the Carrying Straws up in the Trees was simply to pick the rice contained in the headsI saw this day thousands of them-particularly found of Catle pens, alighting close to them and hunting in the fresh Dung in the manner of the Uropean Starling 


\section{SATURDAY January $6^{\text {th }}$ I 82 I}

the Thermother fell by Sun rise to 30 . We had some ice on the running Boards; after So much Warm weather experienced since the Latitude 33 this felt very uncomfortable, and our Litle Stove was good Company, the Wind blew hard ahead Yet-I drew slowly, the Tern I Killed Yesterday; Joseph Made his first attempt from Nature on the femelle-I was very much pleased with his assay-the wind falling aloft

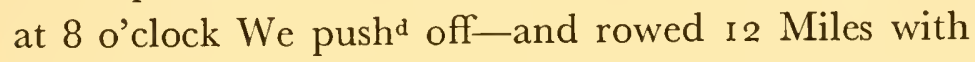
much Dificulty, I did not expect our Commander would Leave our harbour with as dull a prospectWe were blowed a Shore opposite Monsieur St Armand's Sugar Plantation-

Out on Shore with Guns imediately-the Swamps about 3 Miles back we gave up going to them fearing the departure of our boat while absent that far-here Was the finest Plantations we have seen $\mathrm{Mr}$ S. Ad own 70 Negroes and Makes about 400 Hogshead of Sugarbesides raising, Corn Hay, Rice \& c-this Gentleman, apparently Young was Shooting Red Winged Starlings, on the Wing for his amusement, had a richly ornemented Doubled Barelled Gun of which he Made excellent use-the Slaves employed at Cutting the Sugar Cane-this they perform with Large heavy Knifes not unlike those used by Butchers to Chop-some cutting the Head of the plants and others the Cane itself- 
tying the Last in small fagots with the Tops. Carts with Entire Wooden Wheels drawn by 4 oxen haul it to the House where it is, bruised, pressed [and] Boiled \& Made into Sugar-the Miserable Wretches at Work begged a Winter Falcon We had Killed, saying it Was a great treat for them; the Overseer a Good Looking Black Man, told us of his being in the same Employ for 8 Years and had obtain so much of his Master's Confidence, as to have the Entire Care of the Plantation-he Spoke roughly to his under servants but had a good indulgent Eye, and no doubt does what he Can to Accomodate, Master and All-those Immense Sugar Plantations Looked Like Prairies early in Summer for Scarce a Tree is to be seen, and particularly here where the Horizon was bounded by Cleared Land-

We saw Many Catle, Horses, and Sheep, but all poor and Slack, the Latters have but Litle Wool and that only on the back the Rams wear a Long Kind of hairy beard Like Goats-

the Gardens were beautifull. Roses in full bloom revive the Eye of the Traveller-who for lengthy Days has been Confined to the Smoky inside of a Dark flat Bottomed Boat-the Wind entirely Lulled away at Sun Set-the Moon's Disk assured us of a fine Night and We Left our Station to drop within a few Miles of the City-Tomorow perhaps May take us there, yet so uncertain is this World that I should not be 


\section{A UDUBON JOURNAL}

Surprised if I never Was to reach it - the further removed, the Stronger My anxiety to see My familly again presses on My Mind-and Nothing but the astonishing desire I have of Compleating my work Keeps My Spirits at par-

saw a few Fish Crows; a Marsh Hawk-a Red Shouldered Hawk, one the Boatman Killed a Barred Orel, this and the Winter Falcon Much Lighter Colored than usual-

Several Steam Boats passed us going up \& down Length of the Tern 13 Inches - to the end of the tailWings extending 2 Inches beyond, tail I 2 featherstongue Longue Slender and bifid. Mouth orange

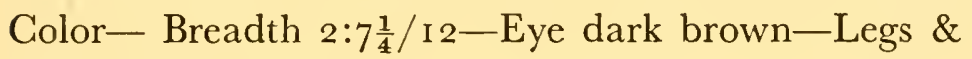
feet red Orange-

\section{Sunday January $7^{\text {th }}$ I 82 I}

at New Orleans at Last-We arrived here about 8 o'clock this Morning; hundreds of Fish Crows hovering near the shipping and dashing down to the Watter Like Gulls for food- uttering a cry very much like the young of the Common crow when they first Leave the Nests-I saw Mr Prentice, who directed me to the House of Messrs Gordon \& Grant where he told me N. Berthoud Was; I saw him and was Introduced to Mr Gordon of whom I shall have opportunity of speaking probably frequently hereafter and the British Consul 


\section{A UDUBON JOURNAL}

Mr Davisson I heard that my familly Was Well, and saw a Note from My Wife to N. Berthoud, that accompanied a $\mathrm{p}^{\mathrm{re}}$ of Gloves made by her for him-

We walked out, Met Col ${ }^{1}$ George Croghan, our former acquaintance saw Many of the Louisville Gentry too tedious to mention names-

Arrived at the House of $\mathrm{Mr}$ Arnauld an old friend of $\mathrm{N} . \mathrm{B}^{d s}$ father. we were invited to take dinner, and although we had engaged previously to $\mathrm{M} r$ Gordon we staid, We had a good dinner and great deal of Mirth that I call french Gayety that really sickened me. I thought Myself in Bedlam, every body talk ${ }^{d}$ Loud at once and the topics dry Jokes-Yet every one appeared good, well disposed, Gentlemen, and were very polite to us-a Monkey amused the Company a good deal by his Gambols and pranks-formerly I would have been able as well as anxious to go to the Theatre but now I can only partake of the Last, and after having paid a Short Visit to $\mathrm{M}^{\mathrm{r}}$ Gordon I retired to the Keel Boat; with a bad head Hake occasioned by drinking some Wine-and very sorry that I probably Could not have Letters from the Post Office untill Tuesday, Tomorow being a grand French Fete the aniversary of the Memorable Batle of Orleans

Joseph had spent his day visiting the Town and was not prepossessed in its favor-

I saw at Mr Arnauld 2 American Doves who have been Caged for Two Years, they Layd Eggs Last Spring, 


\section{A UDUBON JOURNAL}

and incubated them for four days, but they were broke by Accident-

\section{Monday January $8^{\text {th }}$ I 82 I}

at Day breake, went to Market having received information that Much and great variety of game was brought to it-We found Vast Many Malards, some teals, some American widgeons, Canada Geese Snow Geese, Mergansers, Robins; Blue Birds; Red wing Starlings-Tell Tale Godwits-every thing selling extremely high $\$ 1.25$ for one pa $^{\text {re }}$ of Ducks, 1.50 for a Goose \&c Much surprised and diverted on finding a Barred Owl Cleand and Exposed for sale Value $25^{\text {cts }}$ some fine Fish; Indiferent Meat-some Vegetables both of this Country and West Indies = these Latters are put up in Small parcels on the ground opposite the owner, who has fixed prices for each Lot-I went to the review and will remember it and the $8^{\text {th }}$ of January forever-My Pocket was rifled of my pocket Book taken in this Morning with an intention of going to the Governor with the Letters I had received for him, and to Mr Wheeler's brother in Law-when I mentiond My Loss to N. Berthoud he called me a Green Horn, I do not Know the Color of My Horns but well, those of some Neighbours of Mine-

Not blaming fortune as is generally the Case I peaceably pack the whole to Myself and will try to grow Wiser if possible-I think the Knave who took 


\section{A UDUBON JOURNAL}

it is now good deal disapointed and probably wishes I had it - the Parade was only tolerable I had a view of the Governor that is now no doubt all I May expect, he Looked about 6o a french face of good Countenance-We Walked to Bayou $\mathrm{S}^{\mathrm{t}}$ John absolutly to Kill the time, the whole City taken with the festivals of the day-Joseph rec ${ }^{d}$ a Letter from his Parents-

this evening one of our Men Called Smith fell over board drunk and Would have drowned if Providence had not interfered a Women heard the Noise and the Yawl of the S. Bt U. States saw him-

\section{$-9^{\text {th }}$}

Breakfasted with J. B. Gilly. Rec ${ }^{d}$ a letter from My Wife-My Spirits very Low-Weather Cloudy \& Sultry-begun raining paid a Visit to Jarvis the $\mathrm{P}$. Painter-Saw Wam Croghan,-Wrote to My WifeWished I had remained at Natchez-having found No Work to do remained on Board the Keel Boat opposite the Market, the Dirtiest place in all the Cities of the United States-Wrote to John Garnier about My Port Folio-

\section{WedNESDAY Jan' IO $^{\text {th }}$ I 82 I}

Raining hard all day wrote My Brother G. L. Dupuygandeau and to My Mother-in the afternoon Cap $^{n}$ Cummings arrived and dined with us-his appearance much Worst-the Weather so bad that I had 
no opportunity of doing any thing toward procuring Work-Strong thoughts of returning to Natchez Saw $\mathrm{Cap}^{\mathrm{n}}$ Penniston who $\mathrm{rec}^{\mathrm{d}}$ me very Politely

\section{$\longrightarrow$ I I}

Spent the Day Walking about trying to find some work Shewed My Drawings to Mr Gordon \& the British Consul Mr Davisson-spoke good of the Publicationthe former raised My Expectations of their value-

Remarked in Market, Blue Cranes, great Many Coots Caldwall Ducks, some Geese, Keeldeers-I White Crane-or Herons and one Sand Hill Crane-

Was sometime with $\mathrm{Mr}$ Prentice who gave me a letter to Doctor Hunter, whom I wished to see, to procure the Information I so much Need about the Red River, What life \&c-Joseph Employed in Making Enquiries about the Lost Port Folio from every Boat Landing from Natchez-No Work yet-rain, Warm, the Frogs all piping-

\section{- I $2^{\text {th }}$}

Early this Morning I Met an Italian, painter at the Theatre. I took him to N. Bd Room and Shewed me the Drawing of the White Headed Eagle, he was much pleased, took me to his painting appartement at the Theatre, then to the Directors who very roughly offered me roo\$ per Month to paint with Mons L'Italian. 


\section{A UDUBON JOURNAL}

I believe really now that my talents must be poor or the Country-Dined with $\mathrm{M}^{\mathrm{r}}$ Gordon, conversation Birds \& Drawings, Must exibit some again and again as New Guests came in-

I Rec ${ }^{d}$ to day a Letter from My Beloved Wife Dated Nov $^{\mathrm{r}} 28^{\text {th }}$ I 820-gave My Letter for Mr Garnier to the Columbus-No work yet-paid a Visit to Monsieur Pamar but Audubon was poor to day and he Knew it when I made my bow-

Wrote this Evening to Henry Clay Es ${ }^{\text {qr }}$ for another Letter of Recommandation-

Weather, Warm, rainy, foggy, and altogether Disagreable Saw One Wood Cock in Market-

\section{SATURDAY I $3^{\text {th }}$ January I 82 I}

I rose early tormented by many disagreable thoughts, nearly again without a cent, in a Busling City where no one cares a fig for a Man in my situation-I walked to Farvis the Painter and shewed him some of my Drawings - he overlooked [at] them, said nothing then Leaned down and examined them minutely but never said they Were good or badMerely that when he drew an Eagle for Instance, he made it resemble a Lyon, and covered it with Yellow hair and not Feathers-some fools who entered the room, were so pleased at seeing my Eagle that theh prised it, and Jarvis wistled-I called him aside, While Joseph Rolled up our Papers and asked him if he 
needed assistance to finish his Portraits i.e. the Glothing and Grounds-he stared, I repeated my question and told him I would not turn my Back to any one for Such employment and that I had received good Lessons from good Masters-he then asked me to come the following day and Would think about it-

in following $\mathrm{N}$. B. through the street while nothing better could be done, We entered the Warehouse of $\mathrm{Mr}$ Pamar and at once was surprised to hear him ask what I Charged for my Drawings of Faces; 25 \$; but said he I have 3 Children and you May put them all on one piece; then I must have Ioo\$-

$N$. $B^{d}$ requested me to make a Sketch of the Litle Girl then present; a sheet of Paper was procured, My Pencil Sharped and Sitting on a Crate was soon at Work and soon finished; the Likeness was Striking; the Father Smiled, the Clerks stared me emased and the servant was dispatched to shew My Success (as it Was Called) to Mistress-Monsieur Pamar Civilly told me that I Must do my Best for him and Left it to Myself as to the Price-I would have Liked to earn the half of the Money that day, but the Eldest Daughter could not be ready perhaps for several Days-Yet here is found Hopes-how I Calculated on roo Dollars; What relief to My Dear Wife and Children for Said I if I get this, I may send it her and no doubt I will soon procure some more Work-

I spent the remainder of this day in better Spirits 


\section{A UDUBON JOURNAL}

took a Long Walk With Joseph toward the LakeSaw an Aligator-

Wrote this Evening to Doctr $\mathrm{D}^{1}$ Drake-and read some Interesting tales, borrowed from Mr Prentice-

\section{Sunday $14^{\text {th }}$ January I 82 I}

I dispatch Joseph and Simon (N. B. Servant) across the river for some Life Oak to draw, brought some not fit-

Dressed I Went to Jarvis-he took me imediately in his painting room, and asked me many questions, until I thought that he feared my assistance [might become troublesome to him]; he very Simply told me he could not believe that I might help him in the Least-I rose, bowed, and Walk ${ }^{d}$ out without one Word, and No doubt he Looked on Me as I did on him as an Original, and a Craked Man-

The Levee early was Crowded by people of all Sorts as well as Colors, the Market, very aboundant the Church Bell ringing [and] the Billiard Balls Knocking, the Guns heard all around. What a Display this is for a Steady Quaker of Philada or Cincinnati-the day was beautifull and the crowd Increased considerably-I saw however no handsome Woman and the Citron hue of allmost all is very disgusting to one who Likes the [-] rosy Yankee or English Cheeks- 
I took My Gun, rowed out to the edge of the Eddy and Killed a Fish Crow, these Birds are plenty on the River every fair day-(when otherwise, the food is plenty in the Swamps, the Crabs, Young Frogs, Watter Snakes, \& Shewing out in great Numbers)-When the one I Killed fell, hundreds flew to him and appeared as if about to Carry him off, but they soon found it their Interest to let me have him. I drew Near and Loaded for another; they all rose in Circling Like Hawks extremely High and then flew down the Stream, out of sight calling aloud all the times they suffer their Legs \& feet to hang down as if broken-

I brought it on Board and began to Work imediately - at Dark took a Walk to Mr Gordon, from there on to $\mathrm{Mr}$ Laville where We saw some White Ladies and Good Looking ones-returning on Board the Quartroon Ball attracted My View but as it cost I $\$$ Entrance I Merely Listened a Short time to the Noise and came Home as We are pleased to Call it-

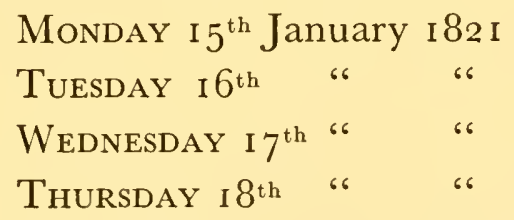

This is a Way of Cutting Matter Short, but indeed the time has been so Long and dull during these days that I think it a good ridince to use them thus [- - ] [I was sad when they passed heavily by] I spent them running about to procure Work, being sadly 


\section{A UDUBON JOURNAL}

disapointed by Mr Pamar who said the Lady Wanted Oil Colors-

Yesterday I Made My Long Acquaintance's Likeness John B. Gilly purposely to expose it to the Public - it is considered by every one who Knows him to be perfect-and to shew it this Morning (for I made it in a few hours) to Pamar procured Me the Making of that of his heldest Daughter; by the time We receive the pay for it, We will be penny Less-

to day I rec ${ }^{d}$ a letter from My Beloved Wife who rufled My Spirits Sadly it Was dated Cincinnati Dec $^{\text {r }}$ 3 I. I 820 I answered it. [- - - - - ]

Saw in Market-2 White Herons-one New Species of Snipe, but could not Draw any of them, being partly pluck ${ }^{\mathrm{d}}$-Joseph Who hunted all day Yesterday, Killed Nothing New-saw Many Warblers-

British Consul's Likeness $\$ 25.00$

I $9^{\text {th }}$ Friday- Euphraim Pamar's Likeness 25.00

20 Saturday- Another Sister " 25.00

2 I Sunday

22 Monday Mrs Pamar

25.00

23 Tuesday Litle Daughter of $\mathrm{D}^{\circ} \quad 25.00$

24 Wednesday $\mathrm{M}^{\mathrm{r}}$ Forestall $\mathrm{D}^{\circ} \quad 25.00$

25 Thursday Young Lucin $D^{\circ} \quad 25.00$

26 Friday $\mathrm{M}^{\text {гв }}$ Lucin Do 20.00

27 Saturday Mr $[-]$ Carabie Do $\frac{25.00}{\$ 220.00}$

28 Sunday Drawing a Brown Pelican- 


\section{A UDUBON JOURNAL}

fatigued, Wearied of Body but in good Spirits having plenty to do at good Prices, and my Work much admired-only sorry that the Sun Sets-

\section{Monday January 29th i 82 I}

Drawing all day the Brown Pelican, Collected My Earnings purchased a Crate of queens Ware for My Beloved Wife, Wrote to her, Wm Bakewell and Charles Briggs forwarding her by Letter and Parcel care of $\mathrm{M} r$ Buckamain of Louisville 270 Dollars-the Crate Cost 36: 33\$-

Tuesday 3oth Mr Duchamp's Likeness 25\$

Wednesday 3 I Nothing disapointed by M. Laville

[THURSDAY " Drew a common gull]

Thursday-February ist i $82 \mathrm{I}$ -

Began a Likeness of $\mathrm{M} r$ Louallier and Drew a Common Gull-

FrIDAY 2d Mr Smith began hunting for Me at $25 \$$ per Month stopped Thursday Morning-and the Girl Began Cooking for us at Io\$ per Month with washing Saturday 3 d Wrote to My Beloved Wife-

Sunday $4^{\text {th }}$ Disapointed again by M. Laville, returned to the Boat and Drew a Grey Snipe- 
Joseph \& Mr Smith out hunting all day, brought a few Red Breasted Thrushes. some Pewee fly Catchers and Many Swamp Sparrows and Savanah FinchesComplaining very Much of the Hardships of hunting in the Cypress Swamps-Remarked in the Market many Purple Galinules but all so Mangled that I could not see one fit to draw-Saw also several Rails or Soras

\section{Monday February $5^{\text {th }}$ I 82 I}

Running about pretty much all day trying to procure some More Work and also Enquiring about Willson's Ornithology, but in Vain-the high Value set on that work now particularly Lately as rendered it extremely rare, and the few who possess it will not Lend it-the Weather extremely sultry and Damp heavy Rains and thunder-saw to day at Mr Pamar, where I often Breakfast or Dine Mr Delaroderie

having been so extremely engaged the Two Days that I Drew the Brown Pelican I had not time to make such Memoranda as I wished-it was given me by Mr Aumack, the Bird was Killed on a Lake in this Vicinity and are rare-it was a Male, in tolerable order-Mr Gordon who before he had seen My Drawing thought it a Pelican Common in some of the West Indies, was much pleased at finding it a diferent Species-I was assured that these Birds were seen in Immense flocks in the Neighbourhood of Buenos-Aires 


\section{A UDUBON JOURNAL}

by a Scotch Gentleman, of respectability-here the hunters call them Grand Gozier and say that seldom more than two are scen together-and only for Short Periods after heavy Gales from the Sea-

the Common Gulls pay us regular Visits With their usual Companions the Fish Crows every Morning about Sun Rise-Comming across the Land from the Lakes Barataria where I am told they resort to Roost -I was not a litle surprised at finding the Stomack of several We Killed a few days since filled with Beetles of different Kinds; Joseph examined the River and found Vast Many of these Last floating dead on the surface, the Crows also feed freely on the Same-the Gulls often chase the Crows for some Considerable distance but Never Successfully, the Crow being much Swifter on the Wing - the quantity of Robins or Red breasted Thrushes Killed here is astonishing, the Market abound with them and yet they bring $6 \frac{1}{4}$ cents each-they are at present the principal Game to be found. Birds of all description are destroyed and eat, our Men Cooked the Gulls and found them excellent food-

I saw 12 of the Grey Snipes Similar to the one I Made My Drawing from, all alike in size and Marking, but the Stupid Ass who sold me one Knew Nothing, Not even where he had Killed them- 


\section{A UDUBON JOURNAL}

\section{February 9 th-I82I-}

In walking this morning about a mile below this city I had the pleasure of remarking thousands of purple martins travelling eastwardly they flew high and circling feeding on [incectes] insects as they went they moved onwardly about $\frac{1}{4}$ miles an hour Thermometer at 68 weather Drisly.

Hundreds of Coots where in the market this morning

\section{FEBRUARY I $5^{\text {th }}$ I 82 I}

Wrote to My Beloved Wife this Day per N. Berthoud List of Drawings Sent My Beloved Wife February I 7 th by Nicholas Berthoud of Shipping port Esqre

I Common gallinule-Not Described by Willson

2 Do-Gull- Do Do Do

3 Marsh Hawk

4 Boat Tailed Grakles Male \& femelle-Not Describd by Willson

\section{Common Crow}

6 Fish Crow

7 Rail or Sora

8 Marsh Tern-

9 Snipe Not Described by Willson

Io Hermit Thrush

I I Yellow Red Pole Warbler

I2 Savannah Finch

I 3 Bath Ground Warbler Not Described by Willson 
I 4 Brown Pelican Not Described by Willson

I 5 Great footed Hawk

I6 Turkey Hen-Not Described by Willson

I 7 Cormorant- Do Do Do

I 8 Carrion Crow or Black Vulture

I9 Imber Diver

20 White Headed or Bald Eagle

May I have the Satisfaction of Looking at these and Many More in good Order on My return the fruits of a Long Journey-

\section{Monday i $9^{\text {th }}$ February i 82 I}

the Weather beautifull, Clear \& Warm, the Wind having blown hard from the Southwest for 2 days \& nights-

Saw this Morning Three Immense flocks of Bank Swallows that past over Me with the Rapidity of a Storm, going Northeast, their Cry was heard distinctly, and I knew them first by the Noise they made in the air coming from behind $\mathrm{Me}$; the falling of their Dung resembled a heavy but thinly falling Snow; No appearance of any feeding While in our Sight-Which Lasted but a few Minutes-

I was much pleased to see these arbingers of Spring but Where could they be moving so rapidly at this early Season I am quite at a Loss to think \& yet their Passage here was about as long after the Purple 
Martins that Went By on the gth Instant as is their arrival in Kentucky a Month hence-perhaps Were they forced by the last Winds and now Enticed to proceed by the Mildness of the Weather the Thermometer being at 68-

how far More south Must I go Next January \& February to see these Millions of Swallows Spending their Winter as Thousands of Warblers, fly Catchers, Thrushes and Myriads of Ducks, Geese, Snipes \&c Do here?

the Market is regularly furnished with the English Snipe Which the french Call Cache Cache. Robins Blue Wingd Teals, Common Teals, Spoon Bill Ducks, Malards, Snow Geese, Canada Geese, Many Cormorants. Coots, Watter Hens, Tell Tale (Godwits, calld here Clou Clou) Yellow Shank Snipes, Some Sand Hill Cranes, Strings of Bleu Warblers, Cardinal Grosbeaks, Common Turtle Doves, Golden Wingd Wood Peckers \&c

\section{Wednesday 2 ist February i 82 I}

I Met this morning with one of those slight discouraging Incidents connected with the life of the artists; I had a Likeness [-] Spoken of in very rude terms by the fair Lady it was Made for, and perhaps will Loose My time and the reward expected for My Labour,-Mrs Andre I here mention the Name as I 
May Speak More of the Likeness as the occasion Will require-

Saw Many Green Baked White Belied Swallows to day and Also four Martins Hiroundo Purpurea-All of them very Lively and not exibiting much of the Muddy Appearance that immersion in the Swamps about this City would undoutedly give them, [if they] had they remained buried in it since Last December at Which time late in that Month they were plenty and remarked passing by [and] ariving from North \& East [Courses(?)] moving South Weswardly -here they Must Make a Long Pause or Move Eastwardly very Slowly as Seldom do they arrive in Pennsylvania before the 25 of [April] March and more frequently in the first days of [May] April-they find nowhere an abondance of Insects, and the Millions of Musquitoes that raise from the Swamps Would Sufice to feed the Swallows of all the World-

\section{Saw Many Brown Larks.}

the Fish Crows are remarkably fond of alighting in flocks on some Pacan trees about 12 Mile below this City about 9 o'clock in the Morning when they retire on these to rest from their Fishing excursions and remain Croaking untill the Midle of the day-

\section{Thursday New Orleans February 22d I82 I}

We at Last have the Keel Boat off and have moved on the hearth again-Our present situation is quite a 


\section{A UDUBON JOURNAL}

Curious one to $\mathrm{Me}$, the room we are in and for which We pay \$Io per Month is situated in Barraks Street near the Corner of that \& Royal Street-between Two Shops of Grocers and divided from them and our Yellow Landlady by Mere Board Partitions, receiving at once all the new Matter that Issues from the thundering Mouths of all these groupes-the Honest Woman spoke much of honesty in Strangers and required one Month paid in Advance, this however I could not do, and satisfied her with one half Not taking a Receipt although She appeared very urgent-

I walked a good deal about the City in search of Work \& Willson's Ornithology but was not favored with any success-extremely anxious to receive some news from My familly-am very much fatigued of New Orleans Where I cannot Shoot Two Birds with one Stone I retired to our Lodgings at Dusk-

Saw Cape Barton's of Henderson who said he would Not have known me if I had not Spoke within his hearing (one half page blotted out)

\section{SAtURDAY 24th February I 82 I}

Idle, and the weather fair, took a Wade in the Woods the vegetation forwarded beyond my expectations. Saw some handsome Plants in Bloom that made me regret of having sent My Drawings home-Birds extremely Shy and nothing New;-in the afternoon 


\section{A UDUBON JOURNAL}

Paid a Visit to Mr John F. Miller from Whom (I was told) I might expect an uncommon Share of Politeness, perhaps I walked in at a bad time but be this as it May, I Was received and Dispatched as promptly as the case would permit; the subject of Course During the few Moments I Left then rolled on Birds. I was asked if Many Ducks such as the Canvas Back \&c (fine food) where residents of this Part of America, had I put those queries I might have expected a No from One that had resided io Years here, and yet this No I Was obliged to give-No doubt for want of True Knowledge for the Birds in question are said to be plenty here during Winter-and are Most Likely are the Sheldrakes Dun Divers and Mergansers having Many of these latters offered for Sale [_ _ - - ]

This Morning the Market was well Stocked with Green Backed Swallows Hiroundo Veridis, the Whole very fat and in beautifull plumage; if these Dear Litle Cherubs have preferred their coats and these flesh so fresh during the pretended Torpor Occasioned by Winter' frost how much more fortunate they are than the Pork Beef \& Butter of Kentucky that sowers however well Salted.

but I have been assured by Men on whom I can rely that some Winters are so Mild that Swallows are seen from time to time during every Months-

the Swallows in Markets Were caught in the holes about houses their resorting places during the Nights 
-this Morning the Weather is Quite Cold, and yet the Swallows are flying about the Street, over the River \&c twitering very Lively-

\section{Sunday $25^{\text {th }}$ February 182 I}

Killed Some Green backed White bellied Swallows Hirondo Veridis-extremely fat, the Gizards completely filled with the remains of Wingd Insects-could not perceive any outward diference between the sexes, the femelles however were well Stored With eggs and the Males strongly marked-the Brother of Mr Pamar Killed a Beautifull White Robin, but his Dog Mangled it so much that I did not draw it - this extraordinary change of Color appeared as the Cause of old age, the Bill of the Bird much worn and the Legs were cicatrised in Several parts, the Bird however was very fat as well as Nearly all the others he killed this Day-

Saw a few Partridges these Birds are here much Sought and hunted down without Mercy, not even do the Sportsmen permit a few Paires to remain untouch \& thereby the race in nearly extinguished Near the City-We Waded to day through an extensive Swamp with hopes of Meeting Some New Species, but Saw Nothing of the Kind to my astounishment-

\section{March Saturday ioth i 82 I}

Sent My Letter to My Lucy, Victor; Wam Bakewell \& N. Berthoud by the steam Boat Car of Commerce- 


\section{A UDUBON JOURNAL}

Saw in Market this Morning some Ampellis Americana Vast Number of Common Snipes but the Robbins have nearly disapeared and are not even to be seen in the Woods-Was assured to Day that the Baltimore Oriole Wintered on the Island of Cuba and that the south west side of this island was the resort of Millions of Swallows during November, December \& January; So strongly was this afirmed that it has determined me to go there Next Winter and to the bay of hondurass, where it is said they also are plenty during these Months Only-

Recd this Morning a Letter from My Beloved Wife dated Shippingport written a few days previous to the one I red by the S. B. James Ross-

This Evening Capn Cummings saw a Night Hawk or a Chuck Will's Widow flying about the Street Near our Lodgings-I presume it was the Latter Bird having been assured that in the first days of April they are seen in numbers at the Bay of St. Louis-

\section{Sunday March I I th I 82 I}

Walkd out this Morning with Joseph to try my Souvenir Gun and found it an excellent One. Shot Many Green Backed Swallows on the Wing-Some red Wing Starlings, Savannah Finches, one fish Crow, \& c-but Nothing New Yet in the Woods, which unfortunately are Now very deep with Watter, the River 


\section{A UDUBON JOURNAL}

being about 4 or 5 feet higher than the ground behind the Levee-

During a Walk this afternoon a Beautifull Mississipi Kite sailed by me, unfortunately I had no Gun.

Near our House a Mocking Bird regularly resorts to the South Angle of a Chimney top and salutes us with Sweetest Notes from the rising of the Moon untill about Midnight, and every Morning from about 8 o'clock untill I I, when it flys to the Convent Garden to feed-I have remarked that Bird allways in the Same Spot and Same Position, and have been particularly pleased at hearing him [try to] Imitate the Watchman's Cry of All's Well that Issues from the fort about 3 Squares Distant, and so well, has he sometimes performed that I Would have been mistaken if he had not repeated too often in the Space of a ro minutes

\section{March I 5 th Thursday $182 \mathrm{I}$}

Wrote to My Beloved Wife and Mr Rob Best Last Night-Saw Many Chuck Will's Widow flying about the streets and some Night Hawks

I Made a Likeness to day for a Lady's Sadle a thing I had not the Leass use for, but the Man I had Made a portrait for, Wanted his Wife's Very Much and Could not Spare Money, and Not to disapoint him I Sufered Myself to be Sadled- 
While at Dinner We were all surprised at the astounishing Leaps that Some Maggots took about our Table.

they Issued out of a Very good piece of Cheese to perform this I remarked them drawing up their heads toward the Tail untill Nearly runing both half of the Body Parell and The Suddenly striking one of the ends Could Not see Which they through themselves about $5^{\circ}$ or 60 Times their Length some time One Way sometimes another apparently in Search of the Cheese-

\section{March I6th FridAY I82 I}

I had the pleasure of receiving a Letter this Morning from Mr. A. P. Bodley dated Natchez 8th Inst Informing me of my Port Folio having been found and Deposited at the office of the Mississippi Republican and that I could have it by writing-

I Acknowledge with a very sensible pleasure the Kindness of Mr. P. who worked his Passage down in Mr Aumack Boats-and at the same time cannot Conceive how the Book had escaped the researches of Mr Garnier-

Mr Gordon had the goodness to write to a friend to have it forwarded imediately and pay whatever charges there might be, the Politeness of that Gentleman is remarkable to a Man who is no more than a Stranger to him, but No doubt it would be impossible for a Good heart to act otherwise- 


\section{AUDUBON JOURNAL}

I took a Walk with my Gun this afternoon to see the Passage of Millions of Golden Plovers Coming from the North Est and going Nearly South-the distruction of these innocent fugitives from a Winter Storm above us was really astonishing-the Sportsmen are here more numerous and at the same time more expert at shooting on the Wing than any where in the U. States [and] on the first sight of these birds Early this Morning assembled in Parties of from 20 to 100 at Diferent places where they Knew by experience they told me the birds pass and arranged themselves at equal distances squatted on their hams, as a flock Came Near every man Called in a Masterly astonishing Manner, the Birds Imediately Lowered and Wheeled and coming about 40 or $5^{0}$ yards run the Gantlet every Gun goes off in Rotation, and so well aimed that I saw several times a flock of i oo or More Plovers destroyed at the exception of 5 or 6-the Dogs after each Voleys While the Shooters charged their Pieces brought the Same to each Individuals-this continued all day, When I Left One of those Lines of Sharp Shooters then the Sun Setting, they appeared as Intent on Killing More as when I arrived at the spot at 4 o'clock-

a Man Near [me] where I was seated had Killed $6_{3}$ dozens-from the firing before \& behind us I would suppose that 400 Gunners where out. Supposing each Man to have Killed 30 Dozen that day I44, ooo must 
have been destroyed-On Enquiring if these Passages where frequent I was told that Six Years ago there was about such an Instance, imediatly after 2 or 3 days of Very Warm Weather a blow from the Northeast brought them, Which Was Nearly the Same to day-some few Were fat but the Greatest Number Lean, and all that I opened showed no food-the femelles Eggs extremely small

\section{SATURday I 7 th March I82 I}

This Morning the Market Was plentifully suplied with Golden Plovers and Pures-I also saw a White Crane. Spent the day Walking about at the exception of an hour Drawing at a Likeness-

\section{Sunday March i 8 th i 82 I}

This Morning I was Witness and in some measure contributed to the presserving of a Tara of a new Kind at Least to Me.-Walking along the Levee to Mr Pamar Where I had an Appointment for a Likeness. I Was Invited to breakfast by Mr A. LiautaudI Walked in and Met a Large Party, Well engaged round an old Gentleman at Pleasing him by the most extravagant round of praises-I understood the Caracter was rather Moony, and very gay When well managed, productive of Much Mirth to his hearersDuring the Breakfast that Certainly Was a good one 
\& on Which One Prince Guest touchd heavily, We were several times struck by unexpected Voleys of Verses, composed for the Occasion, and that could not Indeed have had a better Effect that that produced-Every One enjoyed himself Very Much, particularly the Compositors who were highly Clapped, sometimes to be sure to put an end to his Loquacity.

Breakfast over I was told to remain and see the best part. Mr Liautaud the Learned Guest Was about being recd a Mason and My being a Brother entitled me at once to a seat-this was conducted in the most Ludicrous Manner any one can conceive, and I really pitied the Newly Initiated When all Ceremonies Were over the Man Was Burned in several parts, baptised in a Large Bucket of Watter, Tossed in a Blanket, and Make to Crawl Over about $5^{\circ}$ Casks of Wine, on his belly and Knees, and When at Last given up for want of Invention, the Poor Devils Who had being praying for Mercy during all this was Left in the Necessary-

To this Man this Might be done perhaps again, but few could bear such treatment and I expected several times that his Cries or a Change of sensation from Cowardice to Courage would shew a very diferent scene but all however was Ended as Intended and the poor fellow took it for Granted that he [was] really Was a Mason-

I left and Made Mr Doucillier, Guesnore Likeness1 36 


\section{A UDUBON JOURNAL}

We purchased this Morning in Market a Beautifull Blue Crane the choice of 5 that were nearly alikethose I was told were come earlier than usual. Are extremely dificult of access

I Drew it and its coresponding so well with $\mathrm{A}$. Willson Description stop $d$ me from writing it MyselfTotal Length $30 \frac{1}{2}$ Inches

to end of tail $23 \frac{1}{2}$

Breadth $39 \frac{1}{4}$ "“

Tail Feathers I 2 "

Weight Io Onces-Midle Claw Serrate inwardly The Cotony Substance on the Breast followed the Breast Bones only - and reapeared on each side of the rump-I was assured it a very beautifull Male-

\section{WEDNESDAY March 2 Ist I 82 I}

In reading the Papers this morning at Mr Pamar, I saw the Treaty between Spain and our Country.

the $4^{\text {th }}$ Article Speaking of an expedition to run the Line of Division formed by both Parties and to leave Natchitoches during the Course of this Year; I imediatly went to Mr Gordon to know from him What steps Would be necessary to procure an Appointment as Draftsman for this So Long Wished for Journeyhe advised me to see Mr Hawkins Who would introduce me to Governor Robinson-

I saw Mr Hawkins who very politly promised to 


\section{A UDUBON JOURNAL}

See the Governor and Mention to him my Wishes and to Call at his office on the 23d

to Join in Such an enterprise and to leave all I am attachd to, perhaps for ever, produced Many diferent sensations \& thought, but all are Counterbalanced When persuaded as I am that My Labours [will all be of use to them] are all for their use \& benefit.

I did not wait late on the 23d but My Spirits were sadly dampened when Mr Hawkins told Me that it was the Governor's opinion that nothing more [than common] would be done than to run the Line in question and that none but the surveyors would be Necessary;

Disapointed but not less anxious to try further I Calld on Mr Gordon, he Joined me in the Idea of My Adressing the President Directly and that he could Not think that a Journey so Interesting Would be performd only to say that Men had gone \& Come back-in leaving this truly Kind Gentleman, I Met Mr Grayson of Louisville spoke to him to my thoughts and Wishes.

"I Can render a Service I believe Mr A and I Will do it. I will give you some Letters to diferent Members of Congress With whom I am Well acquainted and that will be glad to Meet Your Views, but Write to the President-

This sounded better to my Ears-

full of My plans I went home \& Wrote to N Berthoud to request his Imediate Assistance-Walkd out 
in the afternoon seeing Nothing but hundreds of New Birds, in Imagination and supposed Myself often on the Journey-

on the 24th I called again on Mr Hawkins. Mr Gordon had spoke of me to him and the former again to the Governor, I spoke of adressing the President, he acquiestd and promissed to give a Letter for the same and procure one from the Governor-

going through the Street Not unlike I dare say a Wild Man thinking too much to think at all My Eyes Were attracted by a handsome faced Man. I Knew him it was My Old Acquaintance \& friend George Croghan. We Met freely and I was eased. he Knew what I was going to say having dined the day previous at the Governor's with Mr Hawkins. he said he had spoke of Me but Would do more and promised to find Some Letters to Mr Hawkins for my use, and Invited Me with such forcible Kindness to go and spend Some time at his Plantation that I Accepted his offer-see me again Walking fast and Looking Wild, but recollecting the high price of time I hunted $\mathrm{M}^{\mathrm{r}} \mathrm{D}^{d}$ Prentice, and asked him if he would form a letter for $\mathrm{Me}$-he answered Yes but told Me that I would do better by writing Myself and that he would freely give his advice and help if Needed-I Was then reduced to My poor thoughts to Express My Wishes[but] Anxious, and Determined to leave no power of Mine untried, I sat to the Paper E' Wrote in as Great 
a Hurry as I am Now doing, a Letter, that Mr Prentice to My utmost astonishment pronounced all suficient-he spoke much about the Journey and anticipated he said the pleasure of reading My Journal on My return-feeling a great Weight off My Shoulders I returned to My Room, took Gun Ammunition \& Joseph \& to the Woods Went in Search of New SpeciesMy Life has been strewed with Many thorns but could I see Myself \& the fruits of my Labour safe, with My Beloved familly all Well on a return from Such an expedition, how gratefull Would I feel to My Country and [Thank]full of the Greatness of My Author-

In Market this Morning I saw Three of What Willson Calls Bartrams's Snipes, they Where very fatare called here Papacots_-Saw a Beautifull White Crane but without legs-Vast Many Green Wingd \& blue winged Teals-hundreds of Snipes, pures, Solitary Snipes-Green back ${ }^{d}$ Swallows-but robbins have disapeared-

The Migration of Birds does Not go a pace with the Vegetable Kingdom in this Part of America When, The Trees are as much in Leaves in Pensylvania, or Ohio, or Kentucky or even the upper Part of Tennessee [Birds] (and this is about the Midle of May) Birds back to the 25 of April have reach ${ }^{d}$ these Parts and are preparing to answer the Calls of Natureto My Astonishment, the Many Species of Warblers, 


\section{A UDUBON JOURNAL}

Thrushes $\&^{c}$ that Were numerous during the Winter have all Moved on Eastwardly and None of the Species that resort this Part have yet reach ${ }^{\mathrm{d}}$ at the exception of Swallows and a Few Watter Birds-

this Would tempt me to believe that Most of Our Migratory Birds Leave their Winter resort [When Influenced by their Natural habits] with such Certainty [in the Weather] of Knowledge about the Weather and Such Swiftness of Movement over the Country as does not give us even the opportunity of remarking their Passage and the greater number [all] at once at the time appointed by the Strength of Passion-

\section{Sunday $25^{\text {th }}$ March 182 I}

Bought a beautifull Specimen of the Great White Heron [grus Americana] in perfect order it had been sent me by a hunter with Whom I had formed acquaintance a few days ago-Worked on it the Whole day and found it the most dificult to Imitate of any bird I have yet undertaken-Took a Walk in the afternoon and heard the Voice of a Warbler new to $\mathrm{Me}$, but could Not reach it-

Monday $26^{\text {th }}$ Walked early this Morning in search of Plants to form the back ground of My DrawingLeft Joseph out who Killed a beautifull, Blue Yellow back Warbler Male Sylvia Pusilla. I had seen some in the Swamp but the litle fellows where so Nimble and brisk that they had all escaped Me-Worked Nearly 


\section{A UDUBON JOURNAL}

all Day Not having time to go and Purchase some articles I wanted to send My Lucy-

Saw $\mathrm{M}^{\mathrm{r}}$ Gordon, who on reading My adress to the President Tura told Me he would Make some Alternation to its form-I left it with him-

\section{Tuesday $27^{\text {th }}$ March I82I}

Drawing at My Heron yet, it Smelt so dreadfully bad that When I opened it I could only take time to See how plainly it proved a Male-the Cottony Substance Was round the breast bone, on each Side of the Vent and on each Side the romp-the Midle Claws very pectinated

I Drew to Day Male \& femelle of the Blue Yellow back Warbler Sylvia Pusilla-and in a Short Walk taken this Evening saw perhaps thousands of the same Species Killed several all alike in their sexes-

forwarded My Beloved Lucy pr Mr Prentice who left at 12 o'clock in the James Ross a piece of Linen, some Stockings, a piece of goods for our Boys and the Woman's Sadle I was almost forced to take some time since-

Gave $\mathrm{Mr}$ Forettale who also went in the same boat an order to get My Port Folio at Natchez and begged of him to forward it to $\mathrm{M}^{\mathrm{r}}$ Gordon- 


\section{A UDUBON JOURNAL}

\section{SAturday March $3^{\text {It }}$ I 82 I}

I spent my time these 3 Last Days More at thinking than any thing else-and often indeed have I thought My Head very heavy-

This Morning I Waited on Mr Gordon with a Wish to receive from him an amendment to my Letter to the President, for all in my head is the Pacific Expedition he Wrote, I read it, but was Not altogether Satisfied-I Called on $\mathrm{M}^{\mathrm{r}}$ Vanderlyn the Historical Painter With my Port Folio-to shew him some of my Birds with a View to Ask him for a few Lines of recommandation-he examined them attentively and Called them handsomely done, but being far from possessing any Knowledge of Ornithology or Natural History, I was quite satisfied he Was No Judge but of their being better or Worst Shaded Yet he spoke of the beautifull Coloring and Good Positions and told Me that he would With pleasure give me a Certificate of his having Inspected them-Are all Men of Talents fools and Rude purposely or Naturally? I cannot assert, but have often thought that they were one or the other.

When I arrived at Mr V's Room, he spoke to me as if I had been an abject slave, and told Me in Walking Away to Lay my Drawings down there the Dirty [-] that he would return presently and Look them over.I felt so vexed that My first Intention Was to Pack off, but the Expedition Was in View, I thought how Long 


\section{A UDUBON JOURNAL}

Kempbell the Actor Waitted Once at the theatre in England, and stood patiently although not Laying My Drawing Down there

About 30 Minutes Elapsed, he returned with an officer and with an air More becoming a Man Who Once Was Much in My situation ask me in his private room. Yet I could plainly see in his Eye that selfish Confidence that allways destroy in some degree the Greatest Man's Worth.

the Swet ran down My face as I hastily opend My Drawings and Laid them on the floor; I Look ${ }^{d}$ up to him. he Was looking at them, the officer's By God that's handsome, struck my eyars Vanderlyn took up a Bird Look ${ }^{\mathrm{d}}$ at it closely put it down and said they Were handsomely done.

I breathed, Not because I thought him a Man of the Most Superior Talents, for to come to such a pitch one Must have no faults, and I With My Eyes half Closed (as you know the pretended Juges of our Day Look at Painting [Look]) saw a great Deffect in One of his figures of Women (the deffect that had being Corrected by the Lady I drew Lately.) but because this Gentleman had some Talents, that he Was Look on as a Very Excellent Judge and that I had been Told that a few Words from him Might be serviceable-of My Likeness he spoke very diferently, the one I had Was fair, hard, and Without Effect, although he Acknowledged it Must have been a Strong one- 
he sat, he Wrote, and I, thinking More of Journeying to the Pacific Ocean, than of Likenesses, Cared Not [Not] a Pecayon about these Later Observations-

as I Was Walking away from his house corner of $\mathrm{St}^{\mathrm{t}}$ Louis and Royal Streets-the Corner of Events the officer who had followed me, ask ${ }^{\mathrm{d}}$ me, the price of My Black Chalk Likeness and where I resided-all answered; I thought how Strange it was that a poor Devil Like me Could Steal the Custom of the Great Vanderlein-but fortune if not blind certainly Most have his Lunatic Moments-the officer said he would Call on Me Liking My Style Very Much-

$\mathrm{Mr}^{\mathrm{r}}$ Hawkings saw this afternoon some of My Drawings and I gave him My Letter to the President. he was apparently Much pleased With both-and told me he Would do all in his Power for $\mathrm{Me}-$

I Put My Letters to My Beloved Wife-N. Berthoud \& Judge Fowles in the [Office] Mail that Leaves every Sunday at 8 o'clock, and return ${ }^{d}$ to our Lodging with a compound of Ideas Not Easily to be described-

I had Shot during a Short Walk I took Yesterday afternoon a White Eyed fy Catcher that the Rats having eat Last Night I could Not of course draw to dayJoseph to day [Drew] Shot a Tyrant Fly Catcher and a Yellow belied Wood Pecker

The Politeness of Mr Vanderlyn Will be remembered-a long time by me; and When ever I Look over these Scrawls it will do me good to have a Litle 
of the same feelings - the following is the Copy of the Lines he handed me-

Mr John J. Audubon has shewed me several Specimens of his Drawings in Natural History-such as Birds, with their Natural Colors, \& other Drawings in plain Black \& White Which Appear to be done With great [accuracy] truth \& Accuracy of representation as much so as any I have seen in any Country-the Above Gentleman wishes $\mathrm{Me}$ to give this as $\mathrm{My}$ Opinion in Writting believing it may Serve as a recommendation to his being employed as a Draftsman in any Expedition to the interiors of our Country.

J. Vanderlyn

New Orleans $20^{\text {th }}$ March I82 I

\section{April $5^{\text {th }}$ I82I}

I have just now recovered My Lost Port Folio $\mathrm{M}^{\mathrm{r}}$ Garnicr sent it me a fortnight ago to the Care of his son the trouble this gave me I will mention hereafterI have to thank $\mathrm{M}^{\mathrm{r}}$ Garnier but More he that found it on the River Bank and took Such very remarkable good Care of it-for on opening it I found the Contents in as good order as the day it Was Lost and Only One Plate Missing-

Blue Yellow Back Warblers

Orchard Orioles

Cardinal Grosbeaks 


\section{A UDUBON JOURNAL}

Yellow Eyed Cuckoos

Large Crested Fly Catchers

White Eyed - " - "

Night Hawks at Dawn of Day Plenty

Turkey Buzards

Carrion Crows

Common Gulls

Carolina Wrens by Vast Number

Partridges a few Very Shy

to see these in hunt of others I Was out since half past 2 o'clock this Morning untill 4 this afternoon Wading often to our Midles through the Swamps and then Walking through the Thickest Woods I believe I had yet seen-

Cape Cummings Left us on the ${ }^{\text {I }}{ }^{\text {th }}$ for Philadelphia the Poor Man had Not One Cent with him-saw Mr Hoyteura who arrived in the Columbus-Rec ${ }^{d}$ by that Vessel Letters from Lucy William Bakewell, Charles Briggs, N. Berthoud-Car of Commerce brought another from My Wife and one from $\mathrm{M}^{\mathrm{r}}$ Mataleon the great flute player-answered

\section{Painted Bunting}

Although these Birds are taken now and quite tamed in a few days, so much so as to sing as if at Large, when Caught Next Month they Die in a few hours, and shew dejection from the Instant they are caged-they are fond of Nesting in Live Oaks, Wild 


\section{AUDUBON JOURNAL}

plum trees, Briars, Orange Groves-when domesticated are fed on Rice-Breed Trice-femelle opened on the I 5 April had Eggs the size of $\mathrm{N}^{\circ} 5$ Shot-

I had from reliable source that One Made his Escape from a Cage and returned Thirty odd Days after to the house, went to the Cage, and remained Many Years-a femelle Was seen in Cage to carry and Arrange the Material given her to form a Nest and Compleated it-but Never Laid-

Saw Some Young Mocking Birds in Market this Morning able to fly-these Birds are said by People here to breed as often as 4 Times during one seasonI also was told that Young Ones sufered to be approach $^{d}$ by the Parents after a separation of Several days are often Poisonned by them, this unatural conduct demands [more] Self Confirmation-

\section{Monday April I $6^{\text {th }}$ I 821}

having received a Visit from $\mathrm{D}^{\mathrm{r}}$ heermann and Lady While hunting Last Saturday, I called on him at his House, he wished I would give a few Lessons of Drawing to $\mathrm{M}^{\mathrm{r}} \mathrm{S} \mathrm{H}-\mathrm{I}$ acquiested and am to begin tomorow;-Joseph Hunting nearly all day Killed a Red Headed Wood Pecker, a Red bellied one[Baltimore] Orchard Orioles, Black headed Titmouse-Green Painted Buntings-drew one With a blue head-Joseph Saw a Yellow Breasted Chat and some Baltimore Orioles- 


\section{A UDUBON JOURNAL}

Spent part of the Day with Mr Hoyteura \& Young Towns of Henderson on Board-

Was sorry as well as Surprised Not to have a Word by the S.B ${ }^{t}$ Manattan from My Beloved Lucy-

\section{Thursday $19^{\text {th }}$-April I $82 \mathrm{I}$}

Low in funds again Left home with my Port Folio My My Best friends as to Introduction and travelled as far as $\mathrm{D}^{\mathrm{rs}}$ Hunter the renowned Man of JeffersonWe Came on him rather unaware the good Man Was P X X X g We Waited and I gave him My Letter of $D^{\mathrm{d}}$ Prentice-

This Phisician May have been a Great Doctor formerly but Now deprived of all that I Call Mind I found it Necessary to leave to his Mill's Drudgery-

Called on a New Phenomena in Painting Mr Earl I believe \& there Saw Mr Earl Jackson-Great God forgive Me if My Jugment is Erroneous-I Never Saw A Worst painted Sign in the Street of Paris-

April Sunday $22^{\mathrm{d}}$ I $82 \mathrm{I}$

Rec ${ }^{d}$ Yesterday a letter from My Beloved Lucy, answered it Last Night and this Morning Wrote to N. Berthoud \& Wan Bakewell sent Home One Box \& I One Bag the Whole by the Steam Boat Car of Commerce that Left at 9 o'clock P.M.

Dinned at Mr Pamar as I usually do on Sundays. My Pupils all religiously inclined did not give them 
Lessons-the great Ease and of Course Comfort that I find in the Company of $\mathrm{M}^{\mathrm{r}}$ Pamar's familly renders my visits at that house quite what I wish and often need for a relief of exersions-Finished to day a Drawing of a Snowy Heron Ardea Candidissima a beautifull Male-Joseph Drawing Flowers all day-

\section{Monday $23^{\text {d }}$}

found in Market a Gallinule that differs much from What I call the Purple one-the Yellow Legs \& feet, their Stoutness - the Blue baby Top-\& all Coloring - the hunters assured me they Never saw One with red Legs-but I cannot depend on their MemoryWe also found another Male of Blue Grosbeak Loxia Purpurea-

Saw My Old Acquaintance John Gwathway of Louisville, he was a la guettee on the Levée the appearance of My Clothes, did Not please him we talk but Litle together.

\section{Tuesday April 24d 182 I}

Much in want of Cash Walked to the Columbus Steam Boat and Made Baxter Town's Portrait for 25\$ - gave My Likeness and Drew the Black Poll Warbler Male-Sylvia Striata, pleased with my days Work, rec ${ }^{d}$ a letter from My Son Victor.-Much pleased also at his improved hand write- 


\section{WEDNESDAY 25-}

Went again on board Columbus rec ${ }^{d}$ My Pay from Towns-Made Mr Hall's Portrait one of the best I believe I ever have taken-Met Gwathway \& Thompson from Louisville- Dined at Mr Pamar had a great Wish to see General Jackson but no time to spare yet -Paid our Board Rent \& Washing to day- 5 \$ for the 2 first Items and 5 for the Latter-raining hard- $\mathrm{M}^{\mathrm{r}}$ Hoyteura still in the Columbus-HIS THOUGHTS-

I am forced here to Complain of the bad figure that My friend Willson has given of the Warbler I drew yesterday, in the Bill only the length exceed that of Nature $\frac{1}{8}$ of an Inch-an enormous diference-and he has runned a broad White line round over the Eye that does not exist-

\section{April Friday $27^{\text {th }}$ I 82 I}

Walked on Board of the Columbus at 6 o'clock this Morning. Made John De Hart's Portrait Mr Hoyteura came a litle before breakfast, had been absent all Night. Much taken by the other passengers

General Jackson Left the City about Twelve I saw him thrice found Vanderlyn's Likeness the Only good One I have seen, Tully's Plate Miserable-John De Hart's Likeness being Intended for Mrs Hall took it there. Spent a few Hours with her extremely agreably -Wrote to Charles Briggs- 


\section{SATURDAY $28^{\text {th }}$ I 82 I}

Rose early and went on Board the Heda to take Mr Bossien Portrait. Made it good Young Guesnore and Hetchberger the Painter spent the Evening with Me, Joseph Sick Wrote to My Beloved Lucy

\section{SUNDAY $29^{\text {th }}$ I 82 I}

Rose purposely to go and collect some Money to forward home, received $105 \$$ sent 100 in a U. S. Note $\mathrm{N}^{\circ}{ }_{1} 5^{2}$ Mark A dated Philad ${ }^{\text {a }}$ April $5^{\text {th }}$ i 8 I 7 , payable at N. O. to B. Morgan's order-I gave it to John De Hart in an open ${ }^{d}$ Letter to remit to My Wife-Columbus left at I 2 o'clock-Dined at Hetchberger Made his Lady's Likeness-coming home Walked in Painter of Feathers' room, very Civil, asked for My CardHoyteura $\mathrm{p}^{\mathrm{d}}$ me a Short Visit Joseph better

\section{Monday April $30^{\text {th }}$ I 82 I}

Steam Boat Paragon arrived No Letter for me$\mathrm{M}^{\mathrm{r}}$ Gordon had one from $\mathrm{M}^{\mathrm{r}}$ Berthoud-sadly disapointed almost sicken, could not do any thing-

\section{May I $^{\text {st }}$ Tuesday i 82 I}

Walked some, Wrote to My Wife but the boat I Intended for, not going-extremely uneasy about My Wife's health or her Children-done Nothing- 


\section{May 2 Wednesday-}

Wrote again to Lucy give the Letter to Baxter Towns [Give Lesson to] drew a Long Legged Plover -Contents Shrimpes \& Insects and at the Diference of Size only found it nearly coresponding to Bewick's description-it was a Male I received it from $\mathrm{M}^{\mathrm{r}}$ Duval the Miniature Painter who assured Me that he had Killed 6 or 7 he leaves here, all alike no diference whatever in the size or Coloring-they are often seen on Lake Borgne during the Summer Months-Was pleased with the Position in my drawing-

\section{Thursday $3^{\mathrm{d}}$}

Bought $15 \mathrm{y}^{\mathrm{ds}}$ Nankeen for Summer Clothesfound $\mathrm{M}^{\mathrm{rs}} \mathrm{H}$ more aimiable if Possible than usual, talked freely to $\mathrm{Me}$-became acquainted With an other Sister-Work ${ }^{\mathrm{d}}$ at $\mathrm{M}^{\mathrm{rs}}$ Hechburgers PortraitWeather fine Monday Morning Very Disagreably Hot - Thermoter, at 88-89-and to day at 3 o'clock in the Shade at 9o-

Cases of Yellow fever in the City I was told-

\section{May Sunday 1821}

$\operatorname{Rec}^{d}$ a Letter by the Cincinnati from My Wife. Not Very agreable to My feelings, surprised at having Nothing from N. Berthoud-appraised Joseph of his Father's Death. Bore it well-Saw Mr Jesse Embrie 
of the Cincinnati Museum $=$ Spent all day very Dull dined at Hetchberger

Monday-Counfounded Hot-Young Guesnore afronted and Ceased Speaking to me-

Tuesday $7^{\text {th }}$ Wrote to My Wife but did not Close my Letter-Mr Hoyteura paid us a Short Visit-Much esasperated against $\mathrm{M}^{\mathrm{r}}$ Gordon- $\mathrm{M}^{\mathrm{r}}$ Gordon sent to England for Me for I $^{\text {lb }}$ Italian Chalk, $6 \mathrm{doz}$ Black Lead Pencils, 2 Grosses Pastels-but did Not advance the Money-

\section{WEDNESDAY $8^{\text {th }}$}

finished My Letter to My Lucy and Wrote a Short One to N. Berthoud-put them on Board the Fayette, the Rose, the one I expected to Leave first Not being ready-thought to day that a Certain Gentleman to Whom I go to dayly felt uncomfortable While I was present, seldom before My coming to New Orleans did I think that I was Looked on so favorably by the fair sex as I have Discovered Lately-

Saw Hoyteura at Mr Hawkins in a High State of Spirits I dare not Call it Intoxication-he sailed this Evening for Liverpool-paid a Visit to the Amiable Vanderlyn, this Gentleman Like all substantial Men gained on acquaintance saw his Portrait of My Fair Pupil $\mathrm{M}^{\mathrm{r} s} \mathrm{H}$ - the Likeness good but roughly painted - he complimented me on My Drawings I thought too Much to be true--saw Gilly about settling for our 


\section{AUDUBON JOURNAL}

Passage to Missingsat should I determine on going there-

Wrote to My Wife, N. Berthoud, Henry Clay, D ${ }^{\imath}$ Drake, on the I $^{\text {th }}$ forwarded all by S.B. ${ }^{t}$ Paragon-

Dined at Governor Robertson, Polite reception, promessed Me a recommendatory letter to $\mathrm{M}^{\mathrm{r}}$ Monroe

No news from $\mathrm{Mr}$ Berthoud yet.-

$$
\text { I } 7^{\text {th }} \text { May I } 82 \text { I }
$$

begun lessons with Young Mr Bollin @ I.50 per Lesson

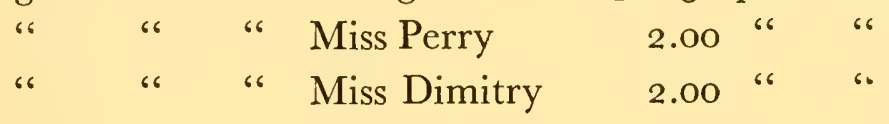

\section{New Orleans May $20^{\text {th }}$ I 82 I}

Sent a few lines to My Wife by the S.B.t Tamerlane-Last Week I Rec ${ }^{d}$ a letter from Mr J. Hawkins and one from $\mathrm{Mr}$ Robertson the Governor for the President of the U. States-favors from Men of High Stations are favors indeed-

The Governor a Man of Strong Information extremely Polite-

Since So long without any news from my familly, My Spirits have failed me, and it is With Dificulty that I sit to Write at all-My Journal Suffers through the same Cause that affects me-attention- 


\section{June $1^{\text {th }}$ New ORLEANS-I 82 I}

Left this City at about $\frac{1}{2}$ past I 2 o'clock-in the Steam Boat Columbus Cape John de Hart-bound to Shippingport Kentucky-

pressed by much work on hand within some weeks passed, during every day, and too much incommodated by Musquitoes at evenings My poor Journal as been put a side [but] events and a wish not to discontinue to put down incidents that are of some Note and agreable to My Mind I come again to it-

a personnage who had some week ago boasted of his Interest towards me, and who on one occasion carried his attention quite too far and awkwardly must first take my attention-and here I will [take the Liberty] give you a Lesson, should you ever be Employed as a Teacher to any ostantatious oppolent person-flatter, Keep flattering and end in flattery or else expect No pay-

My Misfortunes often occur through a want of attention to that Maxim in similar Cases after having with assiduity attended on a Gentleman's Lady (Whose Name I will not at present Mention) for forty Days, I received the rudest of dismisal and My pride would not admit me to the House-to even ask any compensation-how agreable the first Lessons were I shall allways remember. She thought herself endowed with superior talents, and her Looking glass pleasing 


\section{A UDUBON JOURNAL}

her Vanity I dare say made her believe She was a Star dropped from the heavens to ornament this Hearth-but dificulties augmented and of Course drawing seased to please, I could not well find time to finish every piece that I had began for her, and Constancy the Lady said was [not belonging] never to be found the Companion of Genius-toward the Last she Would be unwell when I walk ${ }^{d}$ in, Yawnd and postponed to the morrow-I believe the Husband saw her Weakness, but the good Man Like one or Two More of My Acquaintances Was Weaker still--

I Knew well that My conduct had been correct and I felt a great pleasure in Leaving them, and, the One hundred Dollars I had hearned with them

The Dimitry familly on Whose's Daughters I had the pleasure of attending as a Drawing Master-had become peculiarly agreable and I left them with anxiety for their wellfare and the pleasure that anticipation produces, having some Hopes of seeing them Next Winter,-Young Dimitry I never will forget a Youth of More genuine Natural Ability I never have Met-his sarcastism had much the turn of $\mathrm{D}^{\mathrm{r}}$ Walcot's I Rec ${ }^{d}$ from the Young Ladies Miss Aimee \& Euphrosine Two handsome Plants for My Beloved Lucy that I forward ${ }^{d}$ under the Care of Cape De Hart-

My True friend R. Pamar and his most amiable and Kind Wife I have to thank for all that I can Call 
the pleasures I felt Wilss at New Orleans-I Eat there whenever I could find time, and I was so Loved by the Children that I felt as if I parted from Mine when I left them-I had found ${ }^{d}$ a very slight acquaintance with $\mathrm{M}^{\mathrm{r}} \mathrm{P}$. some years ago as he descended the Ohio on his way home-I had [he said] been Polite to him when he called at My Poor Log House at Henderson and he said often that Kindness had not been profuted to him that he was Well able to remember the Instances and that if I did Not please to Make free with his house he Would be Sorry for it-

I Rec ${ }^{d}$ Many Attentions from Mr Laville and Lady $-\mathrm{M}^{\mathrm{r}}$ Hollander the Partner of My old but too rich Acquaintance Vincent Notte I had the pleasure of seing-he I believe saw that I had No wish to disgrace the Handsome Rich furniture of the Wealthy with My Intrusions when reduced to My Grey Breeches, and taking Me by both Hands One day as I was trying to Make Way from him, he said My Dear Mr Audubon Come and see me. I promise you I shall Not have any one at table and I will try to Raise your Spirits. I have some fine Paintings, and please bring Your Birds that I am Anxious to see-then You see that although I lived extremely retired and general show ${ }^{d}$ those that I thought I Would Incomodate I now \& then stumbled on an Less Indiferent Member of this Life toward his fellows Who like Me have been rich and poor alternatly- 
I had attended a Miss Perrie to Enhance her Natural tallen for Drawing, for some days When her Mother Whom I intend Noticing in due time, asked Me to Think about My Spending the summer and fall at their farm Near Bayou Sarah; I Was glad of such an overture, but would have greatly prefered her Living in the Floridas-We Concluded the Bargain promissing Me 6o Dollars per Month for One half of My time to teach Miss Eliza all I could in Drawing Music Dancing \&c \&c [and the] furnishing us with a Room \&c for Joseph \& Myself-so that after the One hundred Diferent Plans I had form ${ }^{d}$ as Opposite as Could be to this, I found Myself bound for several Months on a Farm in Louisiana.

We left our abode in Quartier Street and Old Miss Louise without the Least regret, the filthiness of her Manners, did not agree with our feeling; and by this time We had fully discovered that a Clean Sweet HouseKeeper is quite Necessary to a Naturalist-

Our Good Spanish Neighbour Mr Taek We Loved, His Nieces sung Well, and his own Jokes now and then amusing us-

We Came to our Landing at the Mouth of Bayou Sarah of a hot sultry day without any accidents; bid farewell to $\mathrm{M}^{\mathrm{r}}$ Gordon and after Mounting the Hill at $\mathrm{S}^{\mathrm{t}}$ Francis Ville Rested ourselves some Moments at a Mr Semple dinner Was set, but Not My Heart for it. I wished Myself on Board the Columbus, I Wished 


\section{A UDUBON JOURNAL}

for My Beloved Lucy, My Dear Boys-I felt that I would be Awkward at table and a good opportunity having offered to go to Mr Perrie place, We Walked slowly on, guided by some of their servants dispatch ${ }^{d}$ with the News of our Coming and some Light Baggage-

the Aspect of the Country entirely New to us distracted My Mind from those objects that are the occupation of My Life-the Rich Magnolia covered with its Odoriferous Blossoms, the Holy, the Beech, the Tall Yellow Poplar, the Hilly ground, even the Red Clay I Looked at with amazement [and] such entire change in so Short a time appears often supernatural, and surrounded once More by thousands of Warblers \& Thrushes, I enjoyd Nature

My Eyes soon Met hovering over us the Long Wished for, Mississipi Kite and Swallow Tailed Hawk, but our Guns Were pack ${ }^{d}$ and We could only then anticipate the pleasure of procuring them shortly-the 5 Miles We Walked appeard Short We Arrived and Met Mr Perrie at his House Anxious to Know him I Inspected his features by Lavaters directions,-We Were received Kindly-

$$
\text { July } 4^{\text {th }} \text { I } 82 \text { I }
$$

during the diferent excursions We have made through the Woods here, and from Report of Such 


\section{AUDUBON JOURNAL}

persons as we thought proper to Lessen to on the subject, I have made the following remarks-Viz-

The Blue Jeay Corvus Cristatus is seen in Lower Louisiana during the summer, not having met with More than a dozen Individuals in All our ramblesLast April Immense Numbers of these Birds, so annoyed the Corn rows in this Neighborhood as to force the planters to Poison them with Corn boiled with Arsenic which had a great Effect-Killed the Thiefs often instantly-

\section{Yellow Bird fringilla Tristis}

Saw a very few during Last Winter Near N. Orleans None at present-Kite do not breed here-

\section{Baltimore Oriole, Oriolus Baltimore}

Not an Individual to be met with at any season-

Wood Thrush Turdus Melodus-

Extremely plenty, in its usual haunts, i.e. deep Shady Woods-the first bird that Sings at the dawn of dayNever Killed one Coresponding with Willson's figure-

Robin-Turdus Migratorius-

Resorts here during Winter in vast Numbers, and becomes very fat-the sport to all the Gunners- leaves early in March-

\section{White Breasted Black Cap ${ }^{d}$ Nuthatch}

Sitta Carolinensis-

Scarce, have Killed a few, Nestle here-Young quite Grown Midle of June, first brood- 
AUDUBON JOURNAL

Sitta Varia Red bellied Nutatch-

Not found-

Gold Wingd Wood Pecker-Picus AuratusPentifull-

Black Throated Bunting, Emberiza Americana Not an Individual Met With

Blue Bird Sylvia Sialis, Scarce, about one pair to each Plantation-Yet Nesting in holes of Peach \& Apple Trees-

\section{Orchard Oriole, Oriolus Nutatus-}

Very aboundant, this Country appears to be chosen by them I found seventeen Nests on Mr Perrie's Plantation With Eggs or Young, during Two days Looking for them-the Young of Many already flying about Midle June-first brood-Was deceived one day by one imitating the Cry of the Loggerhead Shrieke and followed it a great distance before I found My Mistake; it Kept ${ }^{\mathrm{d}}$ on the tops of high trees in the forest, a very unusual circumstance, the figure of Willson has the bill Much too Large \& Long, the figure of the Egg is also too large

Great American Shrieke, Lanius exubitora few seen during Winter-

Ruby Crowned Wren-Sylvia Calendula a few during Winter seen Near N. Orleans-- 


\section{Shore Lark Alauda Apestris-}

None at any season-

\section{Pine Gros Beak-Loxia Enucleator}

None-

Maryland Yellow throat. Sylvia Marilandica Great Numbers during the Winter, Leaves early in March

Yellow Breasted Chat. Pipra Poliglotta As many here as I have met in any other state-that is, One about each Plantation, Never have seen a femelle-

Summer Red Bird, Tanagra Aestiva Tolerably plenty-

Indigo Bunting, Fringilla Cyanea

Tolerably plenty Not so much as in Kentucky or Pennsylvania, but more so than in Ohio-

American Red Start, Muscicapa Ruticilla Very plenty, Young quite grown Midle of June

Cedar Bird Ampellis Americana-

Was remarked this Spring feeding on the Holy berries and remained to reap the fruit of the Wild Cherriesin Immense flocks, extremely fat-disappeared at once-

Red Bellied Wood Pecker, Picus Carolinus pleantifull as any where else 
AUDUBON JOURNAL

Yellow throated fly Catcher Muscicapa SylvicolaNever Met With-

Purple finch-Fringilla purpurea

a few during Winter seen Near N. Orleans-allways in litle flocks of 4 to 6 -

Brown Creeper-Gerthia familiaris-

Not seen-

Not seen-

\section{House Wren-}

Black Capd Titmouse, Parus atricapillus Very plenty-Young quite grown Midle of June-

Crested Titmouse-Parus bicolor the same-

Winter Wren-Sylvia trogloditisduring Winter, Numerous in the Cypress swamps-

Red headed Wood Pecker, Picus Erythrocephalus plenty-Young quite Grown I 5 June-

Yellow Bellied [bellied] Wood Peckera [few] during Winter

\section{Hairy Wood Pecker-}

Not seen-

Downy Wood Pecker, P. Pubescens Scarce,-

Mocking Bird-Turdus polyglottus

Extremely plenty-Nestles in all sorts of situations having found Nest in the higher parts of Tall trees in,

$$
\text { I } 64 \ldots
$$


Small Bushes and even between fence rails garded only by the rail imediately over the Nest-the Egg represented by Willson very Litle Like any of the great Number I examined-these Birds Mock indiscriminately every Note of Birds-are very gentle With every thing but the Bird of Prey, these they give chase to and follow a great distance with much apparent Courage-here during Winter-

\section{Humming Bird. Trochilus Colubris-}

Plentifull-Was assured of their existence of Two Species by Many-represented as Much Larger-have Not Met with any individual yet and fear it to be a Mistake-these Birds are easily Caught by pouring sweetened Wine in the Calices of flowers-they fall intoxicated.

Willson erroneously says that this sweet Bird does not sing-I have many times lissened to its Low toned Melody with great pleasure and can assure you that if its Voice was as sonorous as it is varried and Musical it would be considered as surpassed by few other Species-

Towee Bunting-Emberiza Erythropthalma Saw a very few Near New Orleans during Winter Not One found at present-

\section{Cardinal Gros Beak. Loxia Cardinalis}

Extremely plenty-during the Whole season increasing still by vast Numbers that come from the Eastward to spend their Winter here, very depradatory 


\section{A UDUBON JOURNAL}

to Corn Cribs-Young very Large I 5 June, Second brood Hatching-

Scarlet Tanager, Tanagra Rubra

Plentifull-but do not find them by any Means confined to the Interior of the forests, but to the contrary found on the bordering Tall trees of Plantations-

\section{Rice Bunting-Emberiza Oryzivora} passes early in spring from further Southern parts going eastwardly, remarked some Last february and March-

Red Eyed Fly Catchers, Sylvia Olivacea [Muscicapa] plentifull-Young quite grown early in June

Marsh Wren-Certhia Palustris

Never saw one Like Willson's drawing-but have Killed Many Individual of the Marking \& Shape of My Drawings-some of them a few Miles Above New Orleans in April-but never imediatly Near Rivers-

Great Carolina Wren-Certhia Caroliniana[to be seen] almost constantly in sight or hearing about the field or the forest-young full grown now found of damp places-

Yellow Throat Warbler-Sylvia Flavicollis Never Met With-

Tyrant Fly Catcher, Lanius Tirannus plentifull-young full grown now- 
A UDUBON JOURNAL

Great Greasted Fly Catcher-Muscicapa CrinitaVery Common-young full grown, very Timorous \& Shy-

Small green Crested fly Catcher. Muscicapa Querula Extremely plenty-found of the road sides from where it dashes at flies from Low Bushes-

Pewit Fly Catcher-Muscicapa NoncialaPlentifull during winter Near N. Orleans, a few remains in the Hilly parts of Louisiana during summer-

Wood Pewee-Muscicapa Rapax-

Plentifull in the Woods-this bird hunts latter than any of its Genus. I have heard it uttering its Note Long after Dark-

Feruginous Thrush. Turdus Rufus--

have a very few Individuals, that had more the appearance of Lost Strangers, than of happy residents, rarely seeing more than one at a time--

Golden Crown Thrush. Turdus AurocapillaNot Met [Lower than] at all during summer many seen during the Winter Months-

Cat Bird, Turdus Lividus

Not One seen Since Last March When one Evening I saw Many on the Canal row of Willows, the public Walk Near N. Orleans-

[Bay Breasted Warbler-Sylvia Castanea

None Seen- 


\section{A UDUBON JOURNAL}

Chesnut Sided Warbler. Sylvia Pensylva ${ }^{a}$ None seen-

Mourning Warblers. Sylvia PhiladelphiaNever Met with-

Red Cockaded W. Pecker. P. querulus have seen and Killed one Only, but it Lodged and I Lost it-Not seen Near plantations, unless the weather be very Cold-Mostly in Pine Woods-

Brown Headed Nuthatch-Sitta PusillaNever seen-

Pigeon Hawk falco ColumbariusNever Met with-

Blue Wingd Yellow Warbler Sylvia SolitariaNot Met with here

Blue Eyed Yellow Warbler Sylvia CitrinellaSo many of these about New Orleans early in March Nimbly hunting for insects amongst the willows-but could not find one in the month of May, having past I suppose Eastwardly where it is so common in all our orchards-

Golden Winged Warblers Sylvia ChrysopteraNot seen here, a plentiuss bird in the Lower parts of Kentucky- 
Black Throated Blue Warbler-Sylvia CanadensisNever have seen these Birds since I left Pensylvania Very Numerous in the Lower part of that state in April and May-

American Sparrow Hawk Falco sparverius very Common, Nestle allways in hole, mostly that of the Wood Peckers-Young quite grown, Midle of June here--

\section{Field Sparrow Fringilla Pusilla}

Not here-

Not a single Species of Sparrow to be met with at this season-

\section{Yellow Rump Warbler Sylvia Coronata-} remains here during the whole winter, in aboundance - saw them every day every where there was a Tree even in the City of N. Orleans-in May Not one to be found-

Maryland Yellow throat-Sylvia Marilandica plenty during Winter, and very Gentle-

Blue Small grey fly Catcher Muscicapa Coeruleaplenty during summer Nestles in Willows, Keeps in Small parties of 6 or 7 -has much the manner of the Long Tailed Titmouse of Europe-- 
White Eyed fly Catcher-Muscicapa Cantatrixthe Commonest of all the Birds in our Woods-the young of which Two brood are raised in the season full grown [grown] Midle of July-

Saw 3 Red Ibisses pass over the plantation Yesterday-

\section{Chuck-Will's Widow}

Caprimulgus Carolinensis femelle

Yesterday the $25^{\text {th }}$ of July 182 I an Indian of the Choctaw Nation, who habitually hunts for Mr Perrie -brought me a femelle of the Chuck Will's Widow in full and handsome plumage. it Measured One foot in length, 25 Inches in breadth, the tail composed of Ten Feathers is rounded, but has not the White in any degree that Willson Mentions on the inner vanes of the 2 exterior feathers-the Craw of this was filled with the heads of Many of that Kind of bugs commonly called pinching Bugs, One of them a very Curious Large One Armed with Two equal paires of Pincers-

these Birds generally aboundant in this part of Louisiana, and at present very scarce, Not having been able to Meet one in any of our Excursions that often are of Twenty Miles - a few Weeks previous to our arrival they where heard from all parts of the adjacent Woods loud during the day-a few have been seen and a few heard since, all of which have eluded My 
[attempts at seeing and killing then] pursuits - they remain here untill Late in September. I suppose them at this time so occupied in search of food for their young that it has put an end to their Crying-Many of the Planters think that this bird has the Power and Judment of removing its eggs when discovered sometimes several hundred yards - these are usually laid on the bare earth under a Small bush or by the side of a Log-

Saw 3 of these birds on the $20^{\text {th }}$ of August one Evening while I was Watching the arrival of some Wood Ibisses - they flew Lightly in the manner of the Night Hawk but Close to the Cotton plant tops, passing \& repassing by me untill I could see No moreNot one of this Birds have I heard since Early in June-

On the $22^{d}$ a beautifull femelle of this Bird was brought to me by Mr Perrie's Overseer who had Shot it the preceding evening on a Small dead Tree, Where the Chuck Will's Widow had taken a stand to Watch Beatles \& Seiz ${ }^{d}$ on them as they passed by, he saw it raise several times and Catch them in the Manner that Mocking Birds often do While enchanting the observer of his Melodies-this Man's Wife had seen it for Several evenings previous at the same Spot and sport-These Birds differ Much in plumage particularly in being darker or Lighter as they are Older or younger, this had [several] Many Winter eggs; very 
fat-finding [generally] Birds of Migratory habits generally in good order during this season it May be concluded that it is a preparatory occasion Incident to them to Make them to bear the fatigues and probably the unavoidable wants of foods during their travelsthe Stomack of this had entire Locusts-Green Wood Lice, Ground Crikets and 2 of these Long Beetles Called usually by the french Scarabees-as Most Birds at present Many of the Tail \& Wing feathers were tender from the Moult-

$$
\text { July } 26^{\text {th }} \text { I } 82 \text { I }
$$

Rec ${ }^{d}$ yesterday from New Orleans a Packet of Letters, 4 from My Wife, One from Benj. Bakewell \& one from Mr N. Berthoud. much afraid that My Wife has not rec ${ }^{d}$ My Packet for the President forwarded her by the Cap of the Steam boat Car of Commerce-

Remarked to day that a Male of the Orchard Oriole, that I had wounded in the tip of the Wing and Caged had Violent fits of Convultions, that lasted for as much as ten Minutes each, this I atributed to the uncommon exertions he Made to escape through the Wire of the upper part of the Cage-

Yet he eat freely of Fruits and Also rice-

Saw Yesterday an unknown Awk of a Large Size, that at first appcarance I took for an Ash Colored Awk, but at a dash he Made at some Pigeons I was able to see him Well and could not recognize it for any of the 


\section{AUDUBON JOURNAL}

22 Species I am acquainted with-our pieces not being Loaded, I Lost him-

The Martins have for about Two Weeks Every day followed a Course of Conduct quite New to me \& very remarkable, they are seen Every Morning about 50 in Number, the Whole of Which were inabitants of the Boxes put up for them, assembled on the top of a Dead tree Close by the House, from 8 o'clock until dinner time about 2 P.M. they amuse themselves over the Yard, after this the Whole disapear and Spends the Night, I know not where-going every turn they Leave due West-and returning from that point about sun rise-every Morning-do they spend their Night in Large trees at a great distance? or do they fly to \& fro that While to try their power is uncertain; however, I suppose the first Case the true One-

Carrion Crows are extremely attached to their roosting Dead Trees and will spend the Whole of the Summer nights on the Same-Leaving it very late every morning When flying on a long Course they much resemble the True Turkey-flapping their wings 8 or io times then sailing about 50 yards, \& again flap-

Allmost every Genius of Migratory Birds begain to depart as soon as the Young are fully able-saw to day Large flock of the Tyrant fly Catchers going due south- 


$$
\text { July } 29^{\text {th }} \text { I } 82 \text { I }
$$

I had the pleasure of Meeting with Several Red Cockaded Wood Peckers yesterday during a Walk We took to the Pine Woods and [to] procured Two beautifull Males, both alive, being Slightly wounded each in the Wing-the particular \& very remarkable cry of this Bird can be heard at a very considerable distance of a Still day, in articulation which resembles that of the Hairy Wood Pecker, but is much more Shrill $E^{\circ}$ Loud. the Tall pine trees are its Chosen haunts and seldom does it alight on any other Kind of Timberits Motions are quick, gracefull and easy, its Move in all directions either on the Trunk or Limbs, Looking often very cunningly under the Loose pieces of bark for Insects: is more Shy than any of its Genus. Watching attentively all our Movements below, they Kept allways on the opposite side-peeping carefully at us - The second one Shot did not Loose a Moment to think of its Misfortune, the Moment it fell to the ground it Hoped briskly to the Nearest tree and Would soon have reach its top had I not secured itit defended itself With courage and so powerfully did it peck at my fingers that I was forced to let him goConfined in My Hat on my head, they remained still and stubborn. I looked at them several times, when $I$ found them trying to hide their Heads as if ashamed to have lost their Liberty-the report of my 


\section{A UDUBON JOURNAL}

Gun alarmed them every time I shot when they both uttered a Plaintive Cry-

through pain of the Wound or the heat felt in My hat one died before We reach ${ }^{d} M^{r}$ Perrie's housethe other I put in a Cage,- - he imediatly review ${ }^{d}$ the premises hoping about and hunting for a place to Work through, and used his chisel bill with great adroitness finding the Small Chips he cut to the right \& left and having made his way to the floor, run to the Wall and Climbd up it as easily as if the back of his favorite Pine [bark] -had been his post hold, picking between the Bricks and Swallowing every Insect he found-remarking often his looking under Craks and the litle Shelves in the rough wall, I drew him in that position-Sorry I am to have to say that $\mathrm{M}^{\mathrm{r}}$ Willson's Drawing could not have been Made from the Bird fresh Killed or if so it was in very bad order about the head; he having put the Small striek of red feathers of the head imediatly over the Eye While there is a White Line, the red being placed far back of the $[\mathrm{h}]$ ear-and the whole of the wing not at all Marked Like that of the Bird-the sides of the breast is also badly represented, the Lines in Nature are Longitudinal only, and Show more of a bodythe appearance of this Bird when on the pine trees Would Make one suppose it to be Black all over and the Red Line is often covered by the Crown feathers in the living Bird-I first Met with this Species a few 
Miles from Nashville, when on My Way to Philadelphia in 1806 seeing them from time to time untill I left the first range of Mountains Called the Cumberland - of the Nest or time of Incubation I Cannot speak. I am told that during severe winters they will leave the pine Woods and approach Plantations-

the Length of Both those I attentively examined Was $8 \frac{1}{4}$ Inches, Breadth $14 \frac{1}{2}-$

the Gizzard filled with heads of Small Ants and a few Minute Insects-the birds smells strongly of Pine; as I Hope to be soon able to procure the femelle, I May probably with her portrait give More information-

Shot also a Young of the Great White Heron, entirely destitute of the Pendant silky feathers of the Shoulders, but so well grown that it Might easily in that stage be taken for another Species-Killed Two Young of the Snowy Heron, that Where with an old One, Neither of these had the recumbent feathers of the back and their Legs \& feet were all of a Yellowish Green instead of the former Black and feet bright Yellow-Saw some Killdeer plovers. Kind fisher, Green Heron, and a ferruginous Thrush-Low Land bordering Watter courses are usually preferred by these-

The Martins Hiroundo Purpurea-that leave this place daily, Congregate with a parcel raised Near Thompson's Creek, about 5 Miles from this and I 
have no doubt will take their flight from thence, for their Winter resort--

This afternoon having finished My Drawing of the Red Cockaded Wood pecker and satisfied of its Correctness by a Close comparison to the living original I gave it its Liberty, and was glad to think that it must Likely Would do well as it flew 40 to 50 Yards at times and seemed Much refreshed by its return to Liberty-

\section{Wednesday August I ${ }^{\text {st }}$ I 82 I}

We were awakened Last night by a servant desiring that I should rise \& Dress to accompany $\mathrm{M}^{\mathrm{rs}} \mathrm{P}$. to a Dying Neighbour's house, about one Mile,-We Went, but arrived rather late for Mr James O'Conner Was Dead. I had the displeasure of Keeping his body's Company the remainder of the Night. On such Occasions time flys very slow indeed, so much so that it looked as if it Stood Still like the Hawk that Poises in the air over its prey-the Poor Man had drink himself Literally to an everlasting Sleep; peace to his Soul I Made a good Sketch of his head and Left the House and the Ladies engaged at preparing the ceremonial Dinner-the weather Sultry Thermometer at 93-it has Not raised yet this Season here above 96-

Our Sparrow Hawk Was Killed to day by a Hen engaged in guarding her Brood-Nero had become extremely Temeraire, Would Fall on a Grown duck 
as if thinking all Must answer his Wishes when hungry - he flew at liberty about the Place, caught Grasshopers with great ease and Would Catch in the Air any of the unfortunate Small birds Killed in our dayly walks when thrown toward him for food-he regularly refused all putrid flesh, Never Would touch [a] Woodpeckers, but dearly received Bats \& Mice-he had grown handsome from an apparent parcel of Moving Cotton-sailed with the Wild Birds of his Species, returning every Night to the Inner upper part of a Sash in Mr P.'s Room-he seldom made use of the Note of the Old Birds but allmost constantly uttered his Gree, Cree, Cree-

Our Orchard Oriole I gave Liberty to seing that the Departure of every number of his tribe, had rendered him melancholy to excess; I have No doubt that that specie could be Kept in cages Without much trouble, and its Sprightly Songs certainly would well repay for the care employed to furnish them with food \& Drink-

\section{August $4^{\text {th }}$ I 82 I-SAturday}

Louisianna Warbler. Sylvia Ludovicianna. I Shot this morning the same Bird or one of the same Kind that I pursued yesterday [with such anxiety] so eagerly and then without success-and Was Much pleased to discover in it a New Species-during My Chase of yesterday it flew briskly from one tree or small bush to an- 
other Not as if afraid of me, but as if anxious for food, hanging its Wings very much like the Hooded fly Catcher and constantly Keeping its tail much spread like the American Red Start the Only Note it repeated every time it left a place for another Was a simple soft single Tweet, all its Movements extremely quick gave $\mathrm{Me}$ much trouble to Shot it - this Bird I Never have Met before, and of Course I Consider it as a Very Scarce One, its Note attracted me as that of all New species do; More of its habit I would Like to Know-Total Length 5 Inches Breadth 8-Whole upper part of a rich Olive Yellow-deeper on the shoulders \& back, Wing feathers Black edged with bright Olive-tail Much rounded, composed of 12 Feathers the 3 first exterior on each side Outwarding edged with brownish black and Yellow inwardly these edges broadening more as they goes to the Midle feathers that are of a dark brown nearly black edged with Olive-Under wing Coverts rich yellow-under tail Coverts the same, very long-

Eyes, full, Irises deep brown, bill the true Warbler horn cold above and Clay below, very Sharp with a few black bristle tongue forked \& slender-Legs feet \& Claws Yellowish Clay-it proved on dissection a Male, extremely fat-Gizzard containing, remains of Caterpillars, Small beetles and diferent Kinds of Small flies with a few fine Clean Sands-

August $29^{\text {th* }}$ saw Two of those Birds to day a Male \& femelle that I approached and Examined very 
attentively for some Minutes they were in a Low damp \& Shady part of the wood. I Killed the femelle \& have joined it to my drawing of a Male-I was anxious to procure her Mate but the discharge of my Gun so alarmed it that it flew off and I could not see it more-those Birds resemble the young of the Blue eyed Warbler of Willson in much of their plumage but not in Manners and are a scarce species-

* This entry under August $29^{\text {th }}$ is written across the entry of August $4^{\text {th }}$ in a different ink.

\section{Sunday August $12^{\text {th }}$ I82 I}

We left this morning after an early breakfast to go and explore a Famous Lake about $5 \frac{1}{2}$ Miles from this where we were to find (as told) great many Very fine Birds-the walk to it was pleasant being mostly through rich Magnolia Woods, We Killed Two Wood Ducks in a Small pond that we had to leave on a/c of the depth of the Hole, but that were excellently wellcome to Two Red Shouldered Hawks that Carried them off in our Sight-these Last are the only Birds of this Kind I have seen at this season in this part of Louisianna-We saw a singularly rich cold spider that finding a Horse fly just entangled in her Net move to it and covered it in a Moment with the silk of her bag, Shooting it out in a stream and at the same time rolling the fly untill the whole Likened the appearance of a Small oblong ball of White Silk, the Spider then re- 
turn $^{\text {d }}$ to the center of its Net-No doubt this is a Way of preserving the flies when the Spider is Not hungry;-

When we left the ridges We at Once saw a diferent Country in aspect, the Tall White \& Red Cypress being the principal Trees in Sight with their thousand Knees raising Like so Many Loafs of Sugar-Our eagerness to see the Lake engage us to force Our Way through Deep stiff Mud \& Watter-We came to it and saw several Large Alligators Sluggishly Moving on the Surface, Not in the Least disturb ${ }^{d}$ by our Approach-

Saw a White Ibis on a Log where it sat a Long time arranging its feathers using its scythe Shape ${ }^{d}$ bill very dexterously; Could have Killed it but having No boat and afraid of Sending a Dog in the Lake Left it Setting peaceably-

Saw a great Number of Prothonotary Warblers on the Low Bushes of the Swamp-Many Yellow throated Warblers these have all the habits of a Creeper, Moving quickly round, up and down the Limbs and trunks of the Cypress trees, fly swiftly in the Manner of the brown Creeper alighting generally low on the truck assending it searching nimbly for small Insects; these birds [ $I$ have] have so much the appearance of the White $\mathcal{E}^{2}$ Black Creeper that had I not seen one fly directly toward me and discovering then the beautifull \& Rich Yellow Throat I would not have shot one-This however I effected and found Myself in possession of 
a Beautifull Male that Measured $5 \frac{1}{2}$ Inches in Length \& $8 \frac{1}{4}$ in extent answering Willson Description, on Dissection the Bird Was very fat as all the Warblers We Shot Now Are, and had its Gizard filled with shells of Minute Insects-so found of the Cypress trees is this beautifull spirited litle bird that I Was Tempted to Call it the Cypress Swamp Warbler, where it is only to be Met in this part of the Country-

I Was also fortunate in Shooting a Male of the Green blue Warbler-One Week ago I had shot one but Never could find it, there was at this time five in Company, and Within only a few feet of Me Mr Willson shot a femelle on the Cumberland River, and Never any more; about Two Months since I Discovered One in a small swamp Nearer Mr Perrie-these birds sing sweetly, and No doubt breed here. Look Much like the blue Yellow Back Warblers and hang downwards by the feet like these and the Titmouse. Saw only the One I shot to day and having as much as I Know I could Well draw before they would be Spoiled by the heat of the Wheather returned to the House.

This Male Measured 5 Inches in Length and and $7 \frac{3}{4}$ in breadth-All the Colors brighter \& stronger than Willson's femelle, every Tail feather having White on their inner Vane except the Two Midle Ones-so fat was this bird and of so solid a Nature was that [grease][?] fat that it Cut like Mutton fat; its 
gizard Was filled entirely with some Small brown Shelly Insects and the remains of the same Kind that are extremely plenty in the Cypresses of these SwampsShot a Watter Trush, have found Many here.

Went to the Lake that We Visited Last Sunday and in Going there, I Was much pleased to observe that the sound that We heard on Sunday and had taken for the Plaintive Note of the Wood Peewee was in fact that of a Young Mississipi Kite, While waitting for the return of the Parents with food-this Young it seems had Actually remained [it appears] on the same tree Where we had heard it before but could not then discover it-this Morning perceiving that a long Vine reach ${ }^{\mathrm{d}}$ near to the Top of the Tree and hearing the Noise without Knowing it nor where it actually issued from, I Walked toward it still looking up to the Topmost branches When I perceived something Like a dead stick Lodged Cross ways in a limb-I Eyed it particularly and saw it Moved, I Shot at it and the Noise stop ${ }^{d}$ but the Young M. Kite Closed her wings and destroyed the Dead Stik like appearance it had before my fire-I Waited for it to fall, it cried again shortly and I then saw the Old Bird bringing food and alight Close to the young with one of those Large Grass hopers that abound in the Mississipy flats-but the young was too far gone to relish food the Mother exibited much distress and after several trials to Make the young Bird take it it dropt it and taking old of 
her offspring by the feathers of the back carried it off with ease for about 25 yards to another tree where I follow $^{\mathrm{d}}$ and Killed both at One Shot-the Young instead of having the head of a Light blue ash color like its Mother, had it of a handsome buff and remainder of the body Was Nearly black. I intended drawing Both and I purposely hided them under a Log, but on my return some quadrupedes had discovered them and eat them both-I regret much the Loss the young Bird was nearly full grown [but probably the want of Knowledge to procure food] Saw several paires of Ivory Bill Wood Peckers Killed a handsome Male.-Louisianna affords all the Picus Genus of the U. States-

Arrived at the Swamp and there saw a great Number of Small Birds. Shot a beautifull new Species of Fly Catcher Muscicapa, which I Will give you Tomorow when my Drawing of it Will be finished. I had the pleasure of seing Two that appeared Much alike, they were quarelling when I shot at them but fell only One-cannot say any More of this truly handsome bird having never seen any thing of them before to Day-

Saw within a few feet a beautifull Mourning Warbler but Was so situated Knee deep in the Mud that I could Not retrograde without alarming it I preferred gazing at it as it innocently gazed at Me hoping it would fly at a Short distance, but it Moved with a 
Tweet and out of sight in an instant. Much disapointed at My having lost the only oppry I Ever have had of procuring this rare Bird.

Shot several of the Yellow Throated Warbler all alike and all Males the woods were full of them and yet Not a femelle could I Shot-they Move sideways on the small limbs of the Cypress in a Hoping Manner extremely quickly hang often to the ends of Limbs like the titmouse and run up or down the Large Trunks much like the Nuthatches-Killed Many Blue Yellow back Warblers. Saw Many Prothonotarys, several Watter Thrushes that I consider More Like Warblers the Habits of Which genus they exibit to a very great degree and the Bill of Which they [co] have-Alligators as numerous as before basking in the Sun that this day was more than ordinarily uncomfortable-saw several Ibiss at respectful Distances in their common dull postures-

My Litle fly Catcher had only one wing touch ${ }^{\mathrm{d}}$ When I presented Myself to pick it up, it spread its Tail \& open its Wings and Snap its bill [20 or] about 20 times in the [-] Manner that Many of this Genus do when they seize a fly, particularly those that are Nearest the Standard of the Genus.-I seldom have seen a bird of Such Small size With so Large \& beautifull an Eye. I took it home to James Perrie's Es ${ }^{q r}$ and had the pleasure of drawing it While a live and full of Spirit, it often Made off from My fingers by starting 


\section{A UDUBON JOURNAL}

Suddenly and unexpectedly, and then would hop round the room as quick as a Carolina or Winter Wren would have done, uttering its tweet tweet tweet all the while, and Snapping every time I took it up. I put it in a Cage for a few Moments but it obstinatly forced the fore part of its head through the Lower part of the Wires and I relieved it by Confining it in My hat for the Night anxious to see More of its Movements-

Joseph unwell With a sick head Hacke-Length of the Cypress Swamp Fly Catcher Muscicapa Rara, $5 \frac{1}{4}$ Inches -breadth $7 \frac{3}{4}$ Inches [upp] Whole upper parts handsome ash Color appearing blue at a distance, the front of the Head mixed with Yellow, a Yellow Line Surround the Eye that is very Large Iriss deep brown, pupil Black, between the eye \& Bill \& under the eye shaded with darker ash Tail Coverts lighter than the back, tail slightly forked of 12 Feathers all plain bronish ash shafts deep brown as well as those of the wings under tail Coverts Long \& White-the Throat breast belly \& Vent Rich citron Yellow without intermission of Shade in any of these parts. Breast spotted with black [spots] forming small chains fallin to the beginning of the spurious wings-Bill, hooked at the Tip and broad at the base. Legs feet \& Claws horn Colors the last Long \& Sharp Nostrils very prominent, Tongue much Jagged, Mouth flesh color ${ }^{\text {\& }}$ furnish outwardly With Many Long black bristles-it proved a 
Male. Gizzard fleshy filled with wings of different Insects-Cheeks also ash cold My Drawing a very excellent one-finding this Bird very Weak in the Morning Killed it and put it in Whiskey-

\section{Monday 20 ${ }^{\text {th }}$ August-I82 I}

I spent the Night Nearly in pursuit of the Wood Ibiss and although I Killed One I could never find it this Morning. some Fox or Racoon had No doubt a good Repast of it-I saw 4 Coming, sailing \& flapping alternatly; their Necks \& Legs strached out a little over the tops of the Trees a few Moments after sun Setting. No Note, they alighted on the Largest Top Branches of the dead trees in a Large Cotton Plantation, drew their Necks \& Heads on their shouldiers, Standing perpendicularly. Now \& then arranging the feathers of their breast as if to put their Immense bill at Rest on it-I approach ${ }^{d}$ them untill they Were immediatly over My head, but they never minded Me, its growing Dusky I shot at the Largest, it open its Wings and sailed to the hearth without a groan, the others raised and Sailed on Some other trees, the Darkness of the Night then prevented My seing them any More and Also forced Me to Look for the One I had undoubtedly Killed-After a Long Search this Morning begun with the dawn of Day I had to return, fatigued \& Much Disapointed--the Planter and Negroes assured Me that for Many Years these Birds some time as 


\section{A UDUBON JOURNAL}

Many as 60 \& 70 in Numbers, and at other times only a few had resorted to these Dead Trees to roost Nearly said they the round Year, Missing a few Weeks only early in Spring and in Winter. Could Not ascertain the Months-About 2 Weeks since 3 had been Killed the Negroes pronounced their flesh Excellent food-

While sitting waiting for the arrival of these curious Birds saw Several flocks of the White Ibiss and bleu Herons, Moving from the Lake to this rendez-vousing place of Rest to a Large Sand Barr, at the Mouth of Thompson's Creek that empty a few Miles below Bayou Sarah-the first flew in [Waving] single Waving Lines silently-the bleu Herons in acute Angles passing the Word of March from the first to the Last in a Simply Qua, these are easily Known by their drawn in Necks and Notes, the others allways Keeping their Necks at its full Length

these passages take place every Evening from about one hour before Sunset untill Dark When the Noises of the One and the Pure Whiteness of the others are the only evidence of [their] Straglers still being going over-

\section{-August 25-}

Finished drawing a very fine Specimen of a Rattle Snake-that measured 5 7/1 2 feet Weight 6 I $/ 4^{\text {lb }}$ had Io Rattles- 


\section{A UDUBON JOURNAL}

Anxious to give it such a Position as I thought would render it most interesting to Naturalist, I put it in that which that Reptile generally takes when on point to Inflict a Most severe wound-I have examined the Fangs of Many before and their position along the Superior Jaw Bones, but had never seen one Shewing the Whole exposed at the same time having before this thought that the probability was that those Laying Inclosed below the Upper one in Most Specimen Were to Replace these upper ones Which I thought [also] might drop periodically as the Animal Changes its Skin and Rattles-however on Dissection of these from the Ligament by Which they are fixed to the Jaw bones I found them Strongly and I think [with a] permanently [tendency to be] attached \& as followsTwo Superior Next the upper Like (I speak of one side of the Jaw only) connected Well together at the bases \& running parrallel their Whole Length. They had appartures on the upper \& Lower side of their bases to receive the Venom connectivly and the discharging one a short distance from the Sharp points on the inner part of the fangs - the Two next Fangs about one quarter of an Inch below connected and running in the same Manner, but with only one base apperture on the Lower Side of each and the one at the point that issues the venom to the Wound-the $5^{\text {th }}$ rather smaller is also about a quarter of an Inch below, Lonely appertures as in the Secondarius the scales of 
the belly to the Under part of the Mouth where they finished Numbered 170 and 22 from the vent to the tail-My Drawing I Hope Will give you a good Idea of a Rattle Snake although the Heat of the weather Would not permit me to Spend More than 6 hours at it-My amiable Pupil Miss Eliza Perrie also drew the same Snake; it is With Much pleasure that I now Mention her Name expecting to remember often her sweet disposition and the Happy Days spent near her-

Octr IO $^{\text {th }}$ sent $100 \$$ to $\mathrm{M}^{\mathrm{rs}} \mathrm{A}-$

Octr $20^{\text {th }} 1821$

This Morning about 6 o'clock We Left Mr Perrie's Plantation for New Orleans, Which Place we Reachd

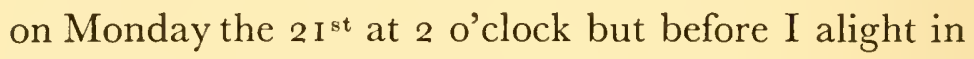
that City, I Must Poise Myself and give you a short $\mathrm{a} / \mathrm{c}$ of the Most Remarkable Incident that have taken Place With us during our Stay at Oakley the Name of James P. Plantation-

Three Months out of the 4 we lived there Were Spent in peaceable tranquility; giving regular Daily Lessons to Miss P. of Drawing, Music, Dancing, Arithmetick, and Some trifling acquirements such as Working Hair \& ${ }^{c}$ Hunting and Drawing My Cherished Birds of America; Seldom troublesome of Disposition, and not Caring for or Scarcely ever partaking or Mixing with the constant Transient Visitors at the House, We Were Called good Men and Now \& then received a 
Chearing Look from the Mistress of the House and sometimes also one Glance of Approbation of the More Circumspect Miss Eliza-Governor Robertson Visited us and then I formed a Still Stronger Opinion of that Man agreableness and Strength of Mind than I had before \& Consider him as a really true Philosopher of the Age-Amongst our other Visitors the Brother of Henry Clay Mr John Clay of this City I found a good agreable Man to all appearance a Rather Singular Caracter Rich Wam Brand also spent some days at the House and Married in the Neighbourhood-All Kindly Polite to us;

Miss P. had No Particular admirers of her beauties but several very anxious for her fortune amongst Which a Certain Mr Colt a Young Lawer Who appeared quite Pressing although Very uncivilly Received at FirstMr P. a Man of Strong Mind but extremely Weak of Habit and degenerating sometimes into a State of Intoxication, remarkable in its Kind, Never associating With any body on such occasions and Exibiting all the Madman's Actions With under its ParoxismWhen Sober; truly a good Man a Free Mason, generous and Entertaining-his wife Raised to opulence by Dint of Industry an Extraordinary Woman-Generous I believe but giving Way for Want of understanding at times to the Whole force of her Violent Passions - found of quizing her husband and Idolatring her Daugher Eliza- 


\section{A UDUBON JOURNAL}

This Daugher Eliza of age I 5 Years of a good form of body, not Handsome of face, proud of her Wealth and of herself cannot well be too Much fed on Praise -and God Knows how hard I tryed to Please her in Vain-and God Knows also that I have vowed Never to try as much again for any Pupil of Mine-as usual $I$ had to do 2/3 of all her Work of Course her progresses Were Rapid to the Eyes of every body and truly astonishing to the eyes of some good observers-

a Sister Mrs Smith I cannot say that I Knew or rather I never did Wish to Know; of Temper Much like her Mother, of Heart Not so good Yet God forgive her the Injuries She did me-

her Husband a good, Honest Man and Citizen Viewed all the faults of her he Wedded With Patient Kindness and felt his reward through his own Correctness of Conduct-I admire him Much-

I saw there a $\mathrm{M}^{\mathrm{rs}}$ Harwood of London England a good Little Woman [and] Very Kind to us in Mending our Linen \& c $^{-}$her Little Daugher a sweet Child about 5 Years Old, Hated by Mrs P.- - Certain Miss Throgmorton Was also good deal Disliked, the poor Girl was nearly drove off as We Were by the Ladies-although she had been Invited there to Spend the Summer-

about a Month before We Left Miss $\mathrm{P}$ was taken seriously Ill, and as she was the only remaining Child unmaried and the $2^{\mathrm{d}}$ of 7,5 of which had died in the Course of a very few years, Much fears were enter- 
tained of the Survival of this One, and No doubt Much too Much Care Was taken of her; Kept in bed Long after She was convalescent and Not permitted to leave her room for a Long time She became, Low of flesh and Crabed of Speech; every thing Must have gone on the Smoothest way to hurt her feelings her Phisician the Man she Loved Would not permit her reassuming her Avavocations near $\mathrm{Me}$ and told the Mother that it would be highly Improper Miss Eliza Should Draw, Write \& ${ }^{\mathrm{c}}$ untill some Months; but that She Might Eat any thing Pleasing to her fancy-this fancy Was not Confined into small bounds. She Eat so plentifully of evering that could be procured that she had several Relapses of fevers-I saw her during this Illness at appointed hours as if I was an Extraordinary ambassador to some Distant Court-had to Keep the utmost Decorum of Manners and I believe Never Laughed Once With her the Whole 4 Months I was there-

$\mathrm{M}^{\mathrm{r}} \mathrm{P}$. on the $\mathrm{I}^{\text {th }}$ of Octr ${ }^{\mathrm{r}}$ Dismissed me-Not anxious to revisit New Orleans so soon, I begged of her that We Should remain 8 or ro Days Longer if the familly Would please to Consider us as Visitors, this agreed on, I Continued My Close Application to My Ornithology Writting every day from Morning untill Night, Correcting, arranging from My Scattered Notes All My Ideas and posted up partially all My Land Birds-the great Many Errors I found in the 
Work of Willson astonished Me I tried to speak of them With Care and as seldom as Possible; Knowing the good Wish of that Man [and] and the Hurry he was in and the Vast Many hear say he depended on-

We perceived however during all this While that a remarkable Coolness had taken place from the Ladies toward us, seldom seing any of them except at table and then With Looks far from Chearing My Spirits that Were during the Whole of My Stay there unfortunatly very Low-M $\mathrm{M}^{\mathrm{rs}}$ Smith took an utter dislike to Me and one day While I was engaged in finish a Portrait of $\mathrm{M}^{\mathrm{rs}} \mathrm{P}$. begun by her Daughter Eliza, $\mathrm{M}^{\mathrm{r} s} \mathrm{~S}$ addresed the Work and $\mathrm{Me}$ in the grossest Words of Insult, and afterwards Never Looked Directly at $\mathrm{Me}-$

She Busted at another time in a ridiculous Laugh at table, When her good Husband Interfered and told her She ought to Make Me some Amends for her Conduct-I Left the table unwilling to hear any More of this-Saturday Came and a Settlement of Money Matter Was Necessary I charged for Io days of Miss E. Ill time My Bill Was 204\$ and Mrs P. in a perfect Rage fit told me that I Cheated her out of 20\$-My Coolness sufered all her Vociferations to flow, I simply told her our former mutual Engagements on that score-I figured the Bill and sent it to $\mathrm{M}^{\mathrm{r}} \mathrm{P}$ Who Was then Labouring under one of his unfortunate fits of antoxication- 
he Came to see $\mathrm{Me}$, apologized in the Kindest Manner for his Lady's Conduct; Ordered his Son in Law Mr Smith to pay Me, and shewed Me all the Politeness he his possessed of $-\mathbf{M}^{\mathrm{r}}$ Smith Congratulated My Firmness of Acting-and All Went on pretty Well that Day-

the Ladies early that Morning Left for St. Francisville Without bidding us any adieu, and expected that on their Return at Night We would be gone; this however was a disapointment for Mr Perrie requested We should Stay, representing how easily We could reach the Steam Boat the Next Morning before her time of departure in the Course of this Afternoon $\mathrm{M}^{\text {rs }} \mathrm{P}$ sent for Joseph and presented him with a full suit of fine clothes of her Deceased son-to the acceptation of Which I positively refused to acquiesce, Knowing too Well how far some gifts are talked of-and Not Willing that My Companion should diminish the Self Respect I think Necessary for every Man to Keep towards himself however poor, when able by Talents, Health and Industry to Procure his own Necessitiesunfortunately there was Much Company in the evening [and] sometimes after supper We Left our Room were Mr Pirrie and Mr Smith had Joined us on leaving the Table to go and bid our farewell to the female Part of the familly-My Entry before the Circle posessed none of that Life and Spirit I formerly Enjoyed on Such Occasion, I would gladly have wished to be ex- 


\section{AUDUBON JOURNAL}

cused from the fatiguing Ceremonies yet $\mathrm{I} \mathrm{Walk}^{\mathrm{d}}$ in followed by Joseph and [Walking] approaching to $\mathrm{M}^{\mathrm{rs}} \mathrm{P}$. bid her good bye as simply as ever any Honest Quaker Did, touch ${ }^{d}$ Slightly Mrs Smith's Hand as I boughed to her-My Pupil Raised from the Sopha and Expected a Kiss from Me-but None Were to be disposed off, I pressed her Hand and With a general Salute to the Whole Made My Retreat No doubt Much to the great Surprise of Every one Present Who had heard those very Women Speak Constantly before of Me in Highest Terms of Respects, scarcely Deigning to Look at me Now-as Joseph Was following me he received a Voley of farewells from the 3 Ladies of the House put after him Ridiculously to Affect Me, but the Effect Was lost and it Raised a Smile on My Lips [and]-We Joined again the Two good Husbands in our Lodging Chamber-they remained with us untill bed time; Cordially parted With us, retired to repose Without Joining the Company-

Day Light of Sunday Saw us Loading our Trunks and Drawing Table. Vaulted our Sadles and Left this abode of unfortunate Opulence without a single Sigh of regret-

Not so with the sweet Woods around us, to leave them was painfull, for in them We allways enjoyed Peace and the sweetest pleasures of admiring the greatest of the Creator in all his unrivalled Works. I often felt as if anxious to retain the fill of My lungs with the 
purer air that Circulate through them. Looked With pleasure and sorrow on the few Virgin blooming Magnolias-the 3 Colored Vines and as We descended the Hills of St Francisville bid that farewell to the Country, that under diferent Circumstances We Would have Willingly divided With the Ladies of Oakley-

We Left the Mouth of Bayou Sarah at Io o'clock in the Morning in the Steam Boat Ramaso with a Medley of Passengers and with a few Stoppages to Land and take occasional Travellers Reached the City on Monday-

the Weather Cool and Rainy, I left the Boat and Walked to My good acquaintance R. Pamar-I had perceived that My Long flowing buckled hair was Looked on with astonishment by the Passengers on board and saw that the effect Was stronger in townMy Large Loose Dress of Whitened Yellow Nankeen and the unfortunate Cut of My features Made me decide to be dressed as soon as Possible Like other folks and I had My Chevelure parted from My head the Reception of Mr Pamar's familly was very gratefull to My Spirits. I Was Looked upon as of a Son returned from a Long Painfull Voyage, the Children, the Parents the servants all hung about Me; What Pleasures for the Whole of us-

I dined there, afterwards Visiting the famous hunter Lewis Adam-and the Dimitry familly who also Received Me very Kindly 
Rented une Chamber garnie in Rue St Anne No 29 for $16 \$$ per Month and removed our baggage thereto from the boat-

We Spent Tuesday Wednesday \& Thursday, Looking over the City for a Suitable House for My Litle Familly-this appeared a very dificult task and I nearly Concluded to take one we visited in Dauphine Street-

My Clothes being extremely Shabby and forced against My Will to provide some New ones, I bought some clothes and Now Wait very impatiently on the Gentleman Taylor for them that I May go and Procure some Pupils with a better grace-

having renewed our early Morning Visits to the Market to Look at all there-We found it allmost as well suplied of Vegetables, fruits, fish, Meats, flowers, $\&^{\mathrm{c}}$ as in the Spring-delightfull radishes Letuce \& ${ }^{\mathrm{c}}$ plenty-Wrote to My Wife yesterday-per Mail it is Now 15 days since I forwarded her a Draft on $\mathrm{M}^{\mathrm{r}}$ Gordon Which May probably have reach to day-

I found at Mess ${ }^{\mathrm{rs}}$ Gordon Grant \& Co a Box of Oil Colors and a Letter from Mr Briggs, I was sorry to See both, the first did not Contain What I Wish, and I Cannot say that I felt any pleasure in Reading the Latter-

I answered Mr Briggs's Letter this Evening-the $25^{\text {th }}$ of Oct O $^{\text {- }}$ 


\section{Octr $25^{\text {th }}$ I 82 I}

Raining hard the Whole of the day spent the greater part of it at R. Pamar and his Relation Lewis Adam the hunter; Rented a House in Dauphine Street for I $7 \$$ Per Month-

Joseph found the time rather Lost to himself Not a Thing to be found to Draw-

$2^{\text {th }}$ Wrote a few Lines to James Pirrie Es ${ }^{q r}$ to Inform him that Mess' ${ }^{\text {rs }}$ D. \& G. Flower had not Paid the House of Gordon \& Co One hundred Dollars according to Promise-Wrote a few Words to $\mathrm{My}$ Lucy and forwarded it by Mail Covering Brigg's Letter;

Walked a good Deal, Visited the familly Dimitry, Spend Much of the Day at Pamar's-in the evening Went some distance down the Levee, the Sky beautifull \& serene-Miss Pamar Much Improved in Music and Manners-Many Men formerly My Friend passed Me without uttering a Word to me and $I$ as Willing to Shun those Rascalls-

fatigued of being Idle so powerfull are habits of all Kinds that to spend a Month thus would render me sick of Life-

Hetchberger Visited us Much Pleased at My addition of Drawings since I Left Cincinnati Octr $12^{\text {th }}$ I 820 I have finished 62 Drawings of Birds E Plants, 
3 quadrupeds, 2 Snakes, 50 Portraits of all sorts and My Father Don Antonio have Made out to Live in humble Comfort with Only My Talents and Industry, Without One Cent to begin on at My Departure-

I have Now 42 Dollars, health, and as much anxiety to pursue My Plans of Accomplishing My Collection as Ever I had and Hope God Will Grant Me the same Powers to Proceed

My Present Prospects to Procure Birds this Winter are More Ample than ever being now Well Known by the Principal hunters on Lake Borgne, BaratariaPontchartrain, and the Country of Terre a Boeuf-

\section{Octr $27^{\text {th }}$ Sunday}

Dressed all new, Hair Cut, my appearance altered beyond My expectations, fully as much as a handsome Bird is when robbed of all its feathering, the Poor thing Looks, Bashfull dejected and is either entirely Neglected or Look ${ }^{d}$ upon With Contempt; such was my situation Last Week-but When the Bird is Well fed, taken care of, sufered to Enjoy Life and dress himself; he is cherished again, Nai admiredSuch my situation this day-Good God that 40 Dollars should thus be enough to Make a Gentleman-ah My Beloved Country When will thy Sons value more Intrinsectly each Brother's Worth? Never!!

Exibited My Drawings at My good acquaintance Pamar's-received much valuable Intelligence corob- 
orating With My own observations on these things that trully pleases My feelings-Dined there-

Payd a Visit to $\mathrm{M}^{\mathrm{rs}}$ Clay and the young Ladies there, with My Portfolio-unknown, Passed for a German untill the latter part of My Stay-the Company Much Pleased With My Work-but no pupil as I expected to have-

took a Long Walk to the Canal, talked Much With My Hunter Gilbert Who Leaves for Barataria Tomorrow-Weather Beautifull and very warm, good Deal of Game in Market this Morning-

Green Back Swallows Gamboling over the City and the River the Whole day have great Hopes of ascertaining their Winter quarters Not far from this

\section{Oct $^{\text {r }} 29^{\text {th }}$ I 82 I}

Spent this unfructuously in search of Employmt Visited several Public Institutions where I cannot say that I Was very politely received; in one or Two Notable ones (Not Willing to Mention Names) I was invited to Walk in and then out in very quick orderDined at Pamar; Was Visited by John Gwathway of Louisville $\mathrm{K}^{\mathrm{y}}$-Wrote to $\mathrm{J}^{\text {d }}$ Rozier to Procure my Drawing of the Male Grous or Prairie Hen-Determined on Exibiting some of My Drawings at Public Places for I Well recollect the effect of Lafontaine Fable that says that "a l'oeuvre on connoit L'Artizan" - unknown by most people here, I am like Many others who appear 


\section{A UDUBON JOURNAL}

as advanturors look ${ }^{\mathrm{d}}$ on with Care, and Suspicionbut so Moves the World, and no doubt it is Wright it should be so-

Visited Rich $\mathrm{M}^{\mathrm{r} s}$ Braud was then very Politely received, "Must Call again"-Mrs Braud Married a Large fortune, the Honey Moon is not yet Set and she Looks well even on her Decline, promising full fullness bye \& Bye-

Rec $^{d}$ a Letter from My Beloved Friend My Lucy unfortunately of old Date, and the one also sent by Mr Ecard dated Nearly 2 Months-

\section{Oct $^{\text {r }} 30^{\text {th }}$ I 821 New Orleans}

Returned to Wam Braud and Procured his Son for a Pupil at $2 \$$ per Leson of one hour, and have some Hopes of having $\mathrm{M}^{\mathrm{rs}} \mathrm{B}$. a pupil of French and Painting-

Visited another College. Politly Received by the Ladies Who examined My Port Folio with apparent siaisfaction. No Pupils however, a Certain Mr Torain having antecedented Me every Where-

Dined at Pamar and Drew My American Hareto Exibit to the Public-Joseph at Work Preparing Father Antoine Coat

the Market Well suplied With game \& Vegetables have resumed our Habit of taking a Walk there as soon as the Day Dawns-

The day Warm, Swallows Plenty and quite as gay in their flight as in June- 
A UDUBON JOURNAL

to find here those Birds in aboundance 3 Months after they have left the Midle States, and to Know that they Winter Within 40 Miles in Multitudes is one of the Gratifications the Most Exquisite I ever Wish $^{\text {d }}$ to feel in Ornithological Subjects and that Puts [an] compleat Dash over all the Nonsense Wrote about their Torpidity during Cold Weather; No Man could ever have enjoyed the Study of Nature in her all Femine Bosomy Wild and err ${ }^{\mathrm{d}}$ so Wide-

\section{Oct $3^{I^{\text {st }}}$ I 82 I New ORleans}

Begun giving Lessons of Drawing to $\mathrm{M}^{\mathrm{rs}}$ Braud and Young Master Wam Braud this Day at 3 Dollars per Lesson-

Spent some time at Work on Father Antoine and My Drawing of My American Hare-

Received a Visit of $\mathrm{M}^{\mathrm{r}}$ Pamar, Mr Dimitry and Dumatras

Weather Warm in the Morning, Much fish Condemned in the Market-also some Game-Excellent regulations-the Wind Shifted to the Northwest and I premidited Cold Weather by the Swallows flying South about noon at Night quite Cool-What Knowledge these Litle Creatures possess and how true they are in their Movements- 


\section{November I ${ }^{\text {st }}$ I 82 I}

Weather beautifull-gave Lessons at Wam BraudsDined at My good Pamar's House--

Very unwell at Night with Violent Cholicks and was forced to My bed at seven o'clock a thing I have not done for Very Many Years-Visited M. Basteros, Painter-

at 12 o'clock Disturbed by the Cries of Fire-but as it Was Not in our imediate Neighbourhood did not Suffer Joseph to go-

\section{November $2^{\mathrm{d}}$-FRIDAY-}

felt Well at day light and Went to see the Market Much Game, but nothing for Me-

gave My Lessons at Wam Braud's-Much pleased to find his Lady possessed of a Natural talent, for Painting Wam Braud extremely Kind and Polite, very anxious to give his Son a good Education-

Rec $^{d}$ the Visit of Brutter the Painter, the good Man Very sorry to see My Father Antonio-fearing an Engraving after it-

I determined to have My Drawing framed although it Cost Me about $30 \$$ having some Hopes that it Would procure Me some Pupils of Note- 


\section{A UDUBON JOURNAL}

\section{Saturday $3^{\text {d }}$ November}

give My Lessons-John Gwathwey announced me the Death of My Constant Enemy Mrs Bakewell My Wife's Mother's in Law-God forgive her faultsEtchberger the Painter spent the evening With us$\mathrm{Mr}^{\mathrm{r}}$ Hails borowed My Shot Bag at Io o'clock P.M. -sufered some Mortifications this Morning in a House Were I showed My Birds-Weather Cloudy \& Raw-

\section{Sunday $4^{\text {th }}$ November N. Orleans}

Breakfasted at Pamar's saw a School Mistress there who requested that I should Call at her House to shew My Drawings-Did so at I I o'clock Tolerable reception there, the Lady Drawing Well herself anxious to acquire My Style but Complaining Much of the extraordinary price I asked her-expect there several Pupils but Nothing very Certain-

Dined at Pamar's, Steam Boat Ramapo arrived Without James Pirrie Esar Much Disapointed on a/c of the Ioo\$ that he was to Pay Mess ${ }^{\text {rs }}$ Gordon Grant \& Co on the $20^{\text {th }}$ ultimo-

took a Long Walk Down the River Shore and out to the Swamps-Swallows More Plenty than yesterday, generally Moving Eastwardly to the Lakes-Weather Delightfull, Much such that is felt in May in Kentucky - Many of the trees having a beautifull set of New 


\section{AUDUBON JOURNAL}

foliage, Vast Many Plants in Bloom-Particularly the Elder-No Lessons at Wam Braud to day-

\section{- Monday $5^{\text {th }}$}

give My Lecons at W. Braud-Drawing at My F. Antoine-Paid Mr Forestal roo\$

\section{Tuesday $6^{\text {th }}$}

gave My Lecons at Wam Braud-Swallows plentyAppearance of Indian Summer Took a Long Walk and Much Work Done at My Drawing

\section{WEDNESDAY $7^{\text {th }}$}

Gave My Lecon to $\mathrm{M}^{\mathrm{r}} \mathrm{B}$ Braud \& Son-Procured Two Pupils to begin Next Monday-Drew an American Avoset-Weather Beautifull-

\section{Brown Pelican-}

Length 4 feet $2 \frac{1}{2}$ Inches from the Tip of the Bill to the end of the Toes, which extend about $1 \frac{1}{2}$ Inches beyong the Tail-The Bill Measured I $2 \frac{1}{2}$ Inches the upper Mandible armed with a strong Hooked Point projecting beyond the blade of the upper Mandible $\frac{1}{2}$ Inch-and fitting the Lower one in its Whole Length to the Nail [the] Which runs to the forehead in Two furrows and Contains the Nostrils that are Extremely small, Linear, within $\frac{1}{2}$ an Inch of the forehead and scarce perceivable-the outer edges of this 
Mandible as Well as that of the Lower and Sharp Cutting edges-3 Process edges are contained in the inner part of the upper Mandible also Sharp edgedthe whole of this upper Part long stiff \& Strong substance-of a Greyish Blue edging in Yellow-the edges of the Lower Mandible are the same Color averaging in Width about $\frac{1}{2}$ an Inch truncated at the end and Capable of distention from their Natural [weigdth] depth of $\mathrm{I} \frac{3}{8}$ of an Inch to 6 Inches and furnished with a tail or pouch of a Bluish Distending Skin begaining at the under point of the Lower Mandible and Loosing itself along the Neck about $9 \frac{1}{2}$ Inches below the Junction of the Mandible from Which part to its utmost stratch point with the hand it Measured a foot-the Tongue is a Mere Knot about 12 Inches from the Tip of the Lower Mandible fast to this Bag-the Eye is Brown pretty Large and situated in the Skin that [so] covers the Cheeks and Jaws of the Bill-the upper of the Head and side of the Neck running along the Pouch of a Mole Cole Color, the hind head ornemented with a Crest of slender feathers of $I \frac{1}{2}$ Inch in Length-the upper Plumage of the Neck, assuming a Silky appearance and Much Worn by resting on the back and Shoulders of the BirdShoulders \& Back Covered With pointed, Small feathers the former Light ash in their Centers edged With Rufous \& Some with brown-the Latter silvery in the Center edge With deep black to the Rump 
Where the Plumage is Larger yet Pointed ash \& Rufous - the Tail Rounded Composed of a 8 feathers quills Black shaded Silvery Ash-the Wings Extended Measured $7 \frac{1}{2}$ feet - the second Joint 9 Inches Closing on the Body reaching to the begainging of the Neckand When closed the Tips reach the end of the Tailthe first 9 Primary quills White to their points below and about $\frac{1}{2}$ above; the feathering [dark] brownish black cast secondaries Much the same-Tertials Broad falling over the back part of the body to the root of the Tail; feathers of the Shoulders of a Light Ash some edged With brown, others With Black, quills very slender and Black-Whole under part White and in some Specimen Silvery-Legs Strong and Muscular far behind-4 Toes Webbed in Connection-the Whole of a Bluish greenish Yellow-Claws blunt, Much Hooked the Longest Pectinated Inwardlythe Bird emitting a Strong disagreable fishy Smell Weighed $6 \frac{1}{2}^{\mathrm{lb}}$ femorals Much as the Shoulders-on dissection it was a Male-the Stomack Very Long and slender, fleshy-Containing only about 50 slender Blue Worm all alive about $2 \frac{1}{2}$ Inches Long-the Gut Measured io feet about the size of a Moderate Swans quill-the Bird Was Killed on Lake Barataria by Mr. Hunter Gilbert-the rump and the root of the Tail Was Covered With a Thin Coating of Oily Yellow fat extremely rancid, and Much air Was Contained between the Whole of the Skin and flesh of the body; 
the Bones of the Wings \& Legs although Extremely hard and dificult to Breake, were very thin [and] Light and perfectly empty-

\section{ThursDAy $8^{\text {th }}$}

gave My Lecons at Mrs Braud's-Weather extremely sultry-Anxious to hear from My Wife-

\section{New Orleans November, Friday $9^{\text {th }}$ I 82 I}

Weather quite Cool a diference in the atmosphere of 22 Degrees from that of yesterday and the Swallows that Were Numerous Last Evening are all gone for the Present—gave My Lecons at Mrs Braud's-

Carried My Port follio to $\mathrm{M}^{\mathrm{rs}}$ Dimitry this morning to Show Miss Euphrosine the Progress of JosephDined and Breakfasted at Good Pamar's-

Visited this afternoon Miss Bornet's academy of Young Ladies and shew ${ }^{d}$ some Drawings-but all to No purpose the Ladies there entirely in favor of $\mathrm{M}^{\mathrm{r}}$ Torane Talents-

Mr Hawkins during My absence brought an Engraving of Vanderling's head of Adriane for $\mathrm{Me}$ to Copy and requested Joseph to tell Me Not to spare My Time on it-Mr Bartrop also Called While I was out-My feelings Much harrassed about My Beloved Wife from Whom I have Not heard for 2 Weeks- 
Gave My Lecons at $\mathrm{M}^{\mathrm{r}} \mathrm{s}$ Braud-Called on $\mathrm{M}^{\mathrm{r}}$ Hawkins who visited me to see father Antoines Drawing-Concluded to have the Engraving he Wished Me to Copy for not exceeding $50 \$$ wishing it could be done as soon as possible-Saw Mr John Clay-very Polite to $\mathrm{Me}-$

Weather Very beautifull but Cold Drew a female of the Gadwall Duck a remarkably fine Specimensent Me by My Hunter Gilbert-

$\mathrm{Mr}^{\mathrm{r}}$ Basterop at My Lodgings-Wished that I should Join him in a Painting of a Panorama of this Citybut My Birds My Beloved Birds of America feel all my time and nearly My thoughts I do not Wish to See any other Perspective than the Last Specimen of them Drawed-No News from My Beloved Lucy nor Children, Very uneasy on their Silence-Mississipi falling fast-

\section{New Orleans Sunday November I I $^{\text {th }}$ I 82 I}

Saw John Gwathway early this Morning, who told me that My Wife Intended Leaving Louisville about the first Instant in a Small Steam Boat for this Place -and this News Kept me Nearly Wild all day. Yet No Boat arrived No Wife No Friend yet near-

The Weather Beautifull \& Warm Dined at Pamar -Drew a good Deal. Visited Basterop-Joseph hunt- 


\section{A UDUBON JOURNAL}

ing all day With Young Dimitry. Killed NothingSwallows Very plenty and as gay as could be-Saw some Common Gull, but Not a Fish Crow come yet$\mathrm{Mr}^{\mathrm{r}}$ Bermudas Visited Me a short time this EveningThe Nearer the Moment that I Expect to see My Beloved Lucy Approaches the greater My Impatience, my disapointment Dayly When evening draws on-

\section{MondAy $12^{\text {th }}$ I 82 I}

Began Given Lessons to Miss Delafosse and Miss at 2 Dollars per hour for both-

Gave My Lecon also at Mrs Braud-Saw Eliza Throgmorton there-Weather Beautifull but $\mathcal{N}_{0}$ DucksDrew a good Deal-Dined at Pamar-had a Conversation Mr John Clay Respecting Mr P $-\mathrm{M}^{\mathrm{r}}$ Bermudas brought $\mathrm{Me}$ a Green Winged Teal as a great RarityNo News from My Wife yet-

\section{TuEsDaY i $3^{\text {th }}$}

Gave Lecons at $\mathrm{M}^{\mathrm{rs}}$ Braud but Miss Lafosse Wishes only to receive them 3 times per Week-Drew a Wild Goose Not represented by Willson-Weather quite Cool-Very Busy all day (The white fronted)

Wednesday New ORleans November $14^{\text {th }}$ I 82 I

Wednesday-gave My Lecons at Mrs Braud's and Miss Delafosse's

Work Constantly the whole day-Drew a female of 


\section{A UDUBON JOURNAL}

the White Nun or Smew Merganser-Weather Rainy \& Raw-Dined on Bread \& Cheese-Rec ${ }^{d}$ a Letter from $\mathrm{M}^{\mathrm{rs}}$ A. the purport of Which Lower My Spirits very Considerably-alas were does Comfort Keep herself now; retired certainly on a Desolate Rock unwilling to Cast even a Look on our Wretched Species-

$\mathrm{M}^{\mathrm{r}}$ E. Fiske formerly our Agent in this City presented $\mathrm{Me}$ this morning with a bill of Fellows \& Rugles-I Spoke to him on that subject in Terms that astonished him, but My determination is bent and I Shall Philosophise Now on all things-Little Expectations of seing My familly before the Latter Part of Winter-

\section{Thursday $5^{\text {th }}$}

Gave Lesson at $\mathrm{M}^{\mathrm{r} s}$ Braud's-

Drew Closely all day finishing 3 Drawings of Birds and Continued after sun set by Candle light untill Io at Vanderlyn's Head-

Weather fair but Cool-Very Low of Spirits Wished Myself off this Miserable Stage-

$$
\text { I } 6^{\text {th }}
$$

FRIDAY

Gave Lesson to Mrs Braud-but Miss Delafosse Was unwell and Postponed taking untill tomorow-Sent a Bill to Dr Heermann-it was accepted and Promised Joseph Payment for Next Week 
A UDUBON JOURNAL

$I 7^{\text {th }}$

SATURDAY

Gave Lessons at Mrs Braud's \& Miss Delafosse alsoher Mother Knew My father-Drew Much to day and late this Evening-[Gilbert the Hunter Returnd]

November Sunday $18^{\text {th }}$ I 82 I

Drawing all day; Dined at $\mathrm{M}^{\mathrm{r}}$ Pamar $\mathrm{Rec}^{d}$ a Visit of Philip Guesnore-also one from the famous Hunter Louis Adams Who however had No Knowledge of the Small Merganzer I had drawn

$$
\text { - } 19^{\text {th }}
$$

Monday Gave Lessons at $\mathrm{M}^{\mathrm{rs}}$ Braud, and Miss Dellfosse-these Latters have conetracted to have one every day Much to My satisfaction-Needing this acumulation of Income very Much-

Drew a Black Bellied Darter Male a Superb Specimen-

Was Visited by $\mathrm{M}^{\mathrm{r}}$ Hawkins, an agreable Man Possessing Taste, Information \& Judgment-

\section{$-20^{\text {th }}$}

Tuesday Gave Lessons at Mrs Braud \& Miss Dellfosse Drew Much and finished both My Black Bellied Darter and the Vanderlyn's Head-Shabbily used by Dr Heermann-Who refused Paying My Well earned 
AUDUBON JOURNAL

Bill-Visited by My good acquaintance Pamar-Basterop the Painter, Much Talk With My good Hunter Gilbert Who Procured Me a Superb Specimen of the Great Sand Hill Crane-

Sufering Much from Sore Eyes and Violent Headache the Whole Day-

WEDNESDAY $2 \mathrm{I}^{\text {st }}$

Gave Lessons at $\mathrm{M}^{\mathrm{r}}$ Braud \& Miss Delfose-Drawing all Day at My Whooping Crane-Weather Extremely Sultry-

\section{November ThursDaY $22^{\mathrm{d}}$ I $82 \mathrm{I}$}

Gave Lessons at Mrs Braud-My fair Pupill Miss Delfosse engaged otherwise-Rec ${ }^{d} 40 \$$ on $a / c$ from Mr Hawkins who appeared to be Much Pleased With the Drawing I give him of Arianne-Weather Summer Heat-Swallows Plenty-Rec ${ }^{d}$ a Letter from My Wife. My Spirits yet very Low-Drew Much to day-received I oo\$ from Mr Forestal as Mr Gordon had Not Paid any Money to My Wife at Louisville-

\section{$23^{\mathrm{d}}$}

Friday-Gave My Lessons to $\mathrm{M}^{\mathrm{rs}}$ Braud and Miss Dellfosse-Rainy and Warm-drawing all daybought a Portfollio from Vigny for $8 \$-$ 
Gave My Lessons at $\mathrm{M}^{\mathrm{rs}}$ Braud and Miss Dellfosse and also at Pamar to his Daugher Who exibited the brightest Genius I believe I ever Met With-Miss Dellfosse beautifull and extremely agreable-

Wrote to My Wife and Wam Bakewell and forwarded to cash a Check on the U. S. Bank of Philadelphia Received by $\mathrm{M}^{r}$ Bermudas for me and for Which I Paid ten per cent-of I oo $\$$ Weather extremely changed Cold and Windy-

\section{$25^{\text {th }}$ \\ Sunday}

Weather Very Cold and raw-Gave Two Lessons of Drawing to Euphemie Pamar-

26

Gave My Lessons to Mrs Braud. Miss Dellfosse and Euphemie Pamar-Weather rather Mild-Swallows plenty-Ship Fulton arrived 120 Passengers on Board

\section{November Tuesday $27^{\text {th }}$ I 82 I}

Gave My Lessons at Both Places-Visited the Maire's Lady Mrs Rosignol Who had evinced a desire to see some of My Pencil Productions-Expect her Daughter for a Pupil Weather Charming-Drew 2 Ducks. Called by Willson the Tufted Duck Male \& 


\section{A UDUBON JOURNAL}

female the Clerk of the Steam Boat Ramapo Called on us Mr Laurent an agreable Man

$$
28^{\text {th }}
$$

Wednesday Gave My Lessons at Both Houses Weather fine $\mathrm{Rec}^{\mathrm{d}}$ a Visit from Mr Braud \& his Lady-Basterop Not Much Pleased at this; Drew a good deal

$$
29^{\text {th }}
$$

Thursday-Gave Lessons to $\mathrm{M}^{\mathrm{rs}}$ Braud's only $\mathrm{Rec}^{\mathrm{d}}$ a Letter from My Wife of an older date than the former one-Weather beautifull-Painted Joseph Likeness-

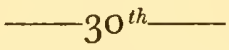

Friday-Gave My Lessons to Mrs Braud's and at Miss Dellfosse-

\section{New ORleans Dec ${ }^{\mathrm{r}}$ I $^{\text {st }}$ i 820 (182 I)}

[Friday] Saturday Gave My Lessons to both houses and Miss Pamar-Rec ${ }^{d}$ a Letter from My Beloved Wife-Expect her in a few Days U. S. Steam Boat arrived-feather uncommonly pleasant $\mathrm{Rec}^{\mathrm{d}}$ this Evening a Non Descript Hawk-

\section{- SUNDAY $2^{d}-$}

Gave 2 Lessons to Euphemie Pamar and One to Miss Dellfosse only-Weather beautifull finished My Drawings of the Crested Hawk Which proved a femalle 


\section{A UDUBON JOURNAL}

with Many Minute Eggs how Rare this bird is I Need Not Say being the Only specimen I Ever have Met with-although I once before found some Tail feathers of another Killed by a Squatter on the Ohio-Which Tail feathers having Kept-Corespond exactly With those of the present bird-

Regret Much that I Cannot Save the Skin but the Weather being Warm and My Drawing having taken Nearly Two Days it was not possible to skin it-

\section{-MONDAY $3^{\mathrm{d}}$}

Gave Lesson to E. Pamar at Mrs Braud and Miss Delfosse-saw $\mathrm{M}^{\mathrm{r}}$ Wheeler who arrived this dayhow little I Expected to have Ever Met with him -Weather quite Warm-

\section{-Tuesday $4-$}

Gave Lessons to Mrs Braud at Miss Delfosse also $\operatorname{Rec}^{d} 40 \$$ from the former and paid the rent of the house in Dauphine Street Weather very Warm drew an American Bitern-

\section{New Orleans Decemb $5^{\text {th }}$ I 82 I}

$\frac{1}{2}$ quire of Paper to Miss Josephine

Wednesday-Gave Lessons at $\mathrm{M}^{\mathrm{rs}}$ Brauds and Miss Delfosse-Weather Cool and Rainy-Visited Basterop and Was Introduced to $\mathrm{Mr}^{\mathrm{r}}$ Sell another of the Trade-another day of Disapointment My Lucy Not 
arrived-Thursday Begun taking \& Giving Lesson to $\mathbf{M}^{\mathrm{r}}$ Lombar Gave My Lessons at $\mathrm{M}^{\mathrm{rs}}$ Brauds and today Miss Delfosse-Mr. Pirrie Arrived to day

\section{$7^{\text {th }}$}

Friday Gave Lessons at Mr Braud's \& Miss Delfosse$\mathrm{M}^{\mathrm{r}}$ Lombar Give Me Lesson on the Violin \& I to his Son of Drawing in Exchange-Rainy Cold all day

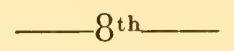

Saturday-Gave Lessons at Mrs Braud's and gave her

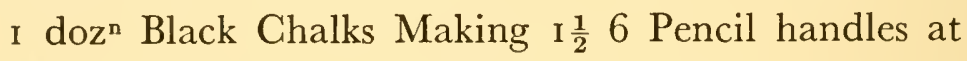
Miss Delfosse and Miss Pamar-at Night Music \& Drawing With young Lombard had the Pleasure of seing $\mathrm{M}^{\mathrm{r}}$ Harwood from London and Rec ${ }^{\mathrm{d}}$ by him My Bitch Belle-Weather Rain \& Cloudy

\section{$9^{\text {th }}-$}

Sunday Weather Extremely Disagreable the Steam Boat Hero arrived from Louisville but No Regular Information about My familly by it--Gave 2 Lessons at $\mathrm{M}^{\mathrm{rs}}$ Pamar where I spent the greater part of the Day-Young Lombar Drawing at my House the Whole Day-

$$
-\mathrm{IO}^{\text {th }}
$$

Gave Lessons 2 to Miss Pamar, Mrs Braud's house and Miss Delfosse-Received a Visit from $\mathrm{M}^{\mathrm{r}}$ Selle \& Mr. Jany Painters- 
New Orleans Dec i ${ }^{\text {th }}$ Tuesday i 82 I

I have but little time to spare at present to write the Many Incidents connected with the Life I am forced to follow for My Maintainance and of Course hundreds of them are passed and forgotten although I am well assured that a Rearsal would at future period amuse My thoughts. One however so curious appeared Me this day that I Cannot let it escapeMay you My Dear Sons reap some benefit from the details

I am a Teacher of Drawing and have some Pupils My Style of giving Lessons and the high rate I charge for My Tuition have proved Me the Ill will of Every other artist in the City who Knows me or has heard of My Maxims-I Called on a Bastard of Appollon this Day to see his Labours I was unknown, tolerably well received and had the pleasure of seing the Animal in action-I also heard his Barkings and saw his Eyes gladening at the sight produced on the canvass before them-a Third unfortunate Dauber came in who it appeared Was an old acquaintance that Criticised at once with ease on all that Was around us-as Every day arrivals by Sea and Land bring New hands to the bellows the Names of Many Were Called forth and Mine amongst them-I Kept Myself and Waited \& the following Picture was given Me Without any Varnishing I assure You-"That Man Came No one 


\section{A UDUBON JOURNAL}

knows from Whence-he goes throu the streets Like the Devil I am told that he has as Many Pupils as he Wishes for and Makes a Wonderfull quantity of What he Calls Portraits and Assures the good folks who employ him that in a few Months by his Method any One May become able Painter-and yet from What I am told the Man Never Drew [but] has bought a set of handsome Drawings of Beasts Birds Flowers, $\&$ Which he Shews and Says are his own-all this a Lye and take in While I Who Was Naturally Intended to Paint Teach \&c am Without a Pupil or Portrait."

here I Took My Hat told the Gentleman where I resided and that I Would be happy to See him giving him the [Two firsts] Initials of My Name only for a Guide-from this Eloquent Member of the Sans Culottes of the Trade, I Moved pretty briskly to $\mathrm{M}^{\mathrm{r}}$ Basterop's Room were in a few Minutes I had the Satisfaction of Seing Mess ${ }^{\text {rs }}$ Jelle \& Janin-all artists and agreable Men. Not Well setled about the a/c of Myself I had so lately heard but thinking how strangely the good Man Will feel when he Calls on Me-if ever he does-

I Gave My Lessons first to Miss Pamar-M $\mathrm{M}^{\mathrm{rs}}$ Braud at Miss Dellfosse and then according to Promise Went to a Pensionnat (were My Young Friend Miss Pamar receives the Larger portion of her Education) to give her regular Lessons of Drawing-When I Entered the 


\section{A UDUBON JOURNAL}

Room, I saw a Degree of Coolness in the appearance of the Lady of the Institution that along With My unfortunate or foolish Natural awkwardness in similar Cases rendered My stay extremely disagreable; My Pupil who is generally Lively and full of Confidence in her actions Was at this time so astonishingly astray from her Work that not a line was properly Copied-I perceived the sarcastic Looks of the Diferent Teachers who Were present going the round and Was highly relieved When the Clock struck My Departure-a few Expressions uttered on My Entering, Joined to a few that reachd My Ears (that burned all this while) as I was Making My Escape Made Me take the resolution Never again to trespass on that Threshold or any other Without first Knowing Well how it May agree with the Will of the first Caracters attached to them [It seems that there are good and bad (-) for everybody]

My Lovely Miss Pirrie of Oackley Passed by Me this Morning, but did not remember how beautifull I had rendered her face once by Painting it at her Request with Pastelles; She Knew not the Man Who with the utmost patience and in fact attention Waitted on her Motions to please her-but thanks to My humble talents I can run the gantlet throu this World without her help

\section{WEDNESDAY $12^{\text {th }}$}

Gave My Lessons at Mrs Braud's-Miss Delfosse absent to day-gave Lesson also to E. Pamar having 
A UDUBON JOURNAL

taken all in Consideration I put aside the Shadow and hang to the bone-and with a White Lye arranged the Matter quite Well With $\mathrm{M}^{\mathrm{rs}}$ Pamar to Whom I had said that I should Not return there any more-

\section{December ThursDay $13^{\text {th }}$ I 82 I}

Gave Lessons at $\mathrm{M}^{\mathrm{r}}$ Braud and E. Pamar Miss Dellfosse finding the Weather Too Cold-So Anxious Am I during the Whole of My present days to see My familly that My head is scarce at right With My Movements and yet I Must feel My sad Disapointments and retire to rest without the comfort of her so much Wanted Company

I saw to day a Work on Natural History with Colored Plates rather better than usual-

\section{4}

FrIDAY Gave Lessons to all this afternoon-but Miss Dellfosse appeared dejected and Work but Indiferently-

It is Now 26 days since the Last Letter I have from My Wife is dated. Three Steam Boats have arrived since from Louisville and No News of her departure have reached $\mathrm{Me}-\mathrm{My}$ anxiety renders every Moment painfull and Irksome-

I Met quite unexpectedly My Pupil Miss Pirrie at $\mathrm{M}^{\mathrm{r} s}$ Brauds, the interview was Short more friendly than I expected and We parted as if We Might see 
each other again With some Pleasure at some future Period-

$$
-15^{\text {th }}-
$$

Saturday Gave My Lessons to All this afternoon Weather Cool \& Clear; feeling much relieved from My Anxiety about My Familly having heard that the Steam Boat the Rocket by Which they are to Come had not Left on the $28^{\text {th }}$ ultimo and that Probably they would Not arrive for 4 or 5 Days yet-

$\mathrm{Mr}^{\mathrm{r}}$ Jany Visited us this Evening and stayed Very Late-

\section{December $6^{\text {th }} 1821$}

Sunday-Gave 2 Lessons to E. Pamar \& 2 to Miss Delfosse only-Weather fine but Cool begun Drawing a Young Swan Sent me by My Hunter Gilbert from Barataria-

Young Lombar at Work all Day in My Room Drawing-

$$
\text { I } 7^{\text {th }}
$$

Monday Gave My Lessons all round-I Drew at My Swan Mr Jarviss paid me a Visit and I returned it imeditly-Gave him 3 pieces of Canvas-Weather very Dark \& Rainy

$$
-\mathrm{I}^{\mathrm{th}}
$$

Tuesday-Gave a Lesson to Miss Pamar and One to $\mathrm{M}^{\mathrm{rs}}$ Braud-My Wife \& My Two sons arrived at 12 o'clock all in good health-I took them to $\mathrm{M}^{\mathrm{r}}$ 


\section{A UDUBON JOURNAL}

Pamar Where We all dined and then Moved to our Lodgings in Dauphine Street after I4 Months absence the Meeting of all that renders Life agreable to Me, was gratefully wellcomed and I thanked My Maker for this Mark of Mercy

$$
\text { - } 19^{\text {th }}
$$

Wednesday I only gave Lesson to $\mathrm{M}^{\mathrm{rs}}$ Braud having much to do arranging My familly-Examined My Drawings \& found them not so good as I Expected them to be; When compared With those Drawn since Last Winter-Bonaparte's Service Was performed this Day here-

$$
-20^{\text {th }}-
$$

Thursday-Gave My Lessons all round-Weather Extremely Warm- $\operatorname{Rec}^{\mathrm{d}}$ a Nondescript Rail

\section{I $^{\text {st }}$}

Friday Gave Lessons at Mrs Braud's \& Miss Delfosse but so Wet and Damp that I declined going to see E. Pamar-Drew a Streaked Rail

\section{New Orleans December 22d I 82 I}

SAturday-Gave My Lessons all round-Weather very Disagreable-Rec ${ }^{d} 20 \$$ on a/c from R. PamarYoung Lombar Resumed his Lessons this Evening having Missed Coming Whilst I was arranging My familly at home- 


\section{$23^{\mathrm{d}}-$}

Sunday Gave 2 Lessons to E. Pamar and I to Miss Delfosse-Weather Extremely Cold-having seen Ice this Morning Nearly one Inch Thick

\section{$-24-$}

Monday Gave a Lesson to E. Pamar Young Braud and 2 to Miss Delfosse-

Weather very Cold-Mr Rozier Came to Pay us a Visit-it is Eleven Years since he [and], I, and My Familly, Were all together-

Tuesday-Gave 2 Lessons to Miss Delfosse but not any were else-

Snowed from Day Light untill Twelve o'clock and afterwards froze hard-

$$
26
$$

Wednesday-Gave 2 Lessons to Miss Delfosse and I to Miss Pamar-Mr Gordon Visited us this Morning and $\mathrm{Mr}$ Colas the Miniature Painter this Evening to see My Birds-

\section{7}

Thursday-Gave 2 Lessons to E. Pamar 2 to Miss Delfosse and One at $\mathrm{M}^{r}$ sraud-Weather beautifullPaid our Rent this Morning-

\section{$-28$}

Friday Gave My Lessons all round 2 to Miss D. 


\section{A UDUBON JOURNAL}

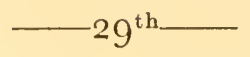

SAturday - Gave My Lessons all round-

$$
\text { Decr SundaY- } 3^{\text {th }} \text { I } 82 \text { I }
$$

Gave I Lessons to E. Pamar and I to Miss DelfosseMr Pamar Dined with us-I Drew this Day a Ferruginous Thrush and am to Draw 99 Birds in that Number of Days for Which I am to Pay One Dollar for each to Robert the Hunter-Who is to furnish Me With One hundred Specimen of Diferent Kinds Should he Not fullil the Contracts, he is to have only $50^{\text {cts }}$ for each furnished

\section{$-3 \mathrm{I}-$}

Monday-Gave 2 Lessons to Miss Pamar I to $\mathrm{M}^{\mathrm{r}}$ Braud and I at Miss Delfosses \& Drew an ampellis Americana

[The following material appears at the back of the journal and is written in from the back cover as a first page. It has no apparent connection with the regularly kept journal.]

Copy of a Letter Written to the Honorable Henry Clay, Speaker of the House of Representatives, Lexington, Kentucky-

\section{SiR}

After having Spent the greater part of Fifteen Years in Procuring and Drawing the Birds of the 
United States with a view of Publishing them; I find Myself possessed of a Large Number of such Specimen as usually resort to the Midle States Only, having a desire to complete the Collection before I present it to My Country in perfect Order, I intend to Explore the Territories Southwest of the Mississipi.

I Shall leave this place about the midle of $\mathrm{Sep}^{\mathrm{r}}$ for the purpose of Visiting the Red River, Arkansas and the Countries adjacent, and Well aware of the good Reception that a few lines from one on Whom our Country looks up with respectfull Admiration, would procure me; I have taken the liberty of requesting such Introductory Aid, as you, May deem Necessary to a Naturalist, While at the Frontier forts and Agencies of the United States

$$
\begin{aligned}
& \text { I Remain } \\
& \text { Respectfully } \\
& \text { Your Ob }{ }^{t} \text { Serv }^{t} \\
& \text { J. J. A. }
\end{aligned}
$$

Cincinnati Ohio $\operatorname{Aug}^{t}$ I $_{2}{ }^{\text {th }}$ I 820

Descriptions of the Water Birds of the United States, with their Generic [arrangement] characters according to the arrangement of Latham as Described by Alexander Willson-the Species discovered by Myself are Marked with My Initials 


\section{Spoon Bill}

Bill Long, thin, the tip dilated, Orbicular, flat, nostrils Small, placed near the base of the Bill, tongue Short, pointed; feet four toed, Semipalmate

Roseate Spoonbill, Platalea ajaja. 7.123

La Spatule couleur de Rose de BrissonI sent Willson from Natchez, Measured 2 feet $6 /$ I 2 and 4 feet in extent, Bill $6 \frac{1}{2}$ Inches Long from the Corner of the Mouth 7 from its upper lap, 2 Inches its greatest Width $\frac{3}{4}$ Inches Narowest place- $-\frac{1}{2}$ Black covered with Scaly protuberances like the edge of oister shells -waitish stained with red-Nostrils oblong in the Midle of the upper Mandible--a deep groove runs along the Mandible about $\frac{1}{4}$ Inch from the edgeCrown \& Chin bare covered with a greenish Skin; that below the Lower Mandible dilatable as in Pelicans-orange round the eye, Irides blood red; cheeks \& hind head bare black Skin; Neck Long covered with Short White feathers, tipt on the Neck with Crimson; breast White its Sides burnt brown Color, a Long tuft of hair Like plumage proceeds from the breast pale rose Color back White Slightly tinged with brownish, Wings pale rose Color, Shafts of same Lake; Shoulders of the Wings covered with Long hairy plumage deep \& splendid Carmine; upper \& Lower tail Coverts Same; belly rosy; rump paler; tail equal at the end 12 bright brownish orange feathers, 
A UDUBON JOURNAL

Shalf redish; Legs and Naked part of the thigh dark dirty red; feet $\frac{1}{2}$ Webbed-toes Very long particularly hind one, inside of the Wing richer than Outside

List of the Watter Birds of North America taken from Turton's Linne

American Avoset, head, Neck \& Breast rufous-Bill Black, Legs pale blue-

Blue Crane, Head, \& Neck dark purple-3 Long narrow pendant feathers 6 Inches beyond EyeLength-23 Inches extent 3 feet

SNowy Heron-2 I/I 2 feet-extent 3 2/1 2-orange yellow round the Eye-Irids vivid Orange-Whole plumage White-(Head Largely Crested-4 Inches) breast Do upper back feathers recumbent and Loose-

Night Heron, Bill Blk $4 \frac{1}{4}$ Inch Skin about eye Blue, Irids Red, Cap ${ }^{d}$ deep Blue-3 White feathers Issuing -Back deep blue-Vent \& belly White, Legs \& feet Light Buff-Length $24 /$ I 2 - extent 4 feet-

Great White Heron Bill yellow, Legs \& feet claws Blk; Whole body White, Back feathers falling far over tail-Length 3 feet 6 to end of tail, 7 or 8 Inches Long to extremities of back feathers-

Stormy Petrel- 


\section{A UDUBON JOURNAL}

Great Tern, Bill \& feet red, Black Cap ${ }^{d}$ tail very forked, upper parts, Light Bluish Ash-Belly white

Lesser Tern, Bill \& Leg Yellow, Blk Cap ${ }^{d}$ tail very forked-

Short Tail Tern, Bill \& Legs Black, Cap \& Cheek Blk, Tail Shorter than Wings-

Black Skimmer-

Spotted SAnd PIPer; Bartram, Sand Snipe, ring plover, Sanderling plover, Golden P. Kildeer P-

Red Breasted Snipe-Long Legged Avoset Bill Blk Red purpleish red, Eye red, whole upper part, Deep Olive, Solitary Sand piper, Yellow Shank Snipe-Tell tail $\mathrm{D}^{\circ}$

\section{[HERONS]}

Turn Stone, Bill Black Leg deep Orange-Breast Side of Neck and Spot under the Eye Black; Much of Brick Color on the Wings-belly White-4 Toes

\section{Ash Colored Sandpiper Legs dull Yellow-4 Toes}

Pure-Bill Black, Legs \& feet $\mathrm{D}^{o} 4$ Toes

Black Bellied Plover-4 Toes the Hind one small and very high

Red Breasted Sandpiper-Bill Short Vent White, Bell breast and under Neck Deep Rufous- 
A UDUBON JOURNAL

Esqumaux Corlew-Legs Greenish Blue-4 Toes

Red Backed Snipe-Bill Much Curved Blk belied Bend

Semi Palmated Snipe-have this

Marbled Godwit-Bill Long rather inclined upwards-

Louisianna Heron, Legs Yellow Bill blue-upper head Purpled, Crest White, Back Feathers very Long Light Buff-Tail, Wing \& Back Deep Blue-

Pin Oister Gatcher-

Hooping Grane-Black Tips-Bill yellow

Long Bill Curlew, Legs Bluish-

Yellow Crowned Heron Bill dark Blue, Legs Yellow White Crested Very Long, throat and Head black with an Oval White Spot-

Great Heron, thigh Deep Rufous, under Crest Long Blk, upper White-Breast, \& Back fathers Long \& Loose

American Bittern, Dirty Yellow Oakre, Zig Zaged with dark Brown-a Black Triangular Line runs from the Mouth to the Back of Neck

Least Bittern- 


\section{A UDUBON JOURNAL}

Wood Ibis Gros BeAK

Scarlet Ibis

FLAMingo

White IBIS

Black Surf Duck Singular Bill-3 White Marks about the head-Legs Red-

Buffel Headed Duak-the Spirit-

Canada Goose

Tufted Duck Bill Blue-Head Neck and breast Blk a Rufous bend on the Lower part of Neck

Golden Eye Duck

Shoveller Duck

Goosander, Head Changeable Green

Pin Tall Duck Sprigg Tail

Blue Wing ${ }^{D}$ Teal

Snow Goose

Pied Duck Legs \& feet Light Ockre, Ring round the Neck Connected with Back, Back Tail Belly and Line over the Eye Black, primaries also Black, the Remainder White

Red Breasted Merganser-have this 
American Widgeon, Bald Pate

Blue Bill-head Neck \& Breast Dark Brown-Back Canvassed-Rump Tail \& Tail Coverts Blk

Hooded or Crested Merganser

Long TAIL Duck-Old Wife

Summer Duck

Green Winged Teal

Ganvas Back Duck

Red Headed Duck-Head and neck half wayBright Rufous-Lower part of Neck \& Breast Blk. Back Canvassed-

MALARD

Cadwall Duck

Eider Duck Male \& femelle

the Smew, the Black Spectacled Goosander

Ruddy Duck, Blue Bill, Legs Rosy-upper head Black, Neck \& whole upper part Brick Color-Cheeks, Chin, \& side of Head White-femelle Dark olive all upper Part-sides of Head Dusty Yellow-Breast transversally Barred with Brick Colored Lines-Belly \& Vent dirty Yellow- 


\section{A UDUBON JOURNAL}

BRANT

Scotter Duck Wholy Black, upper Mandible Yellow - Lower \& Nails Blk-Protuberances Red-Legs Red Velvet Duck-have it Large Blk Sea Duck

HARlequin Duck a Narrow regular White ring around the Lower part of Neck-

A Black Duck A Dusky Duck

Marsh Tern Black Capd Wings, Back \& Tail Light Ash or Blue-the first Very Long the Latter Slightly forked-Legs \& palmate feet Lead-

Sooty Tern-Bill Black, front and whole under part White, upper Blk tail Much forked, the Tips White edged inwardly with Blk

The $9^{\text {th }}$ Volume I believe Contains-the Loon $=$ Purple Galinulle $=$ Coot $=$ Darter $=$ Black Headed Gull $=$ Great Footed Hawk, \& ${ }^{c}=$ 
The typographical format of this volume has been designed by William Dana Orcutt, and the manufacture has been completed at the Plimpton Press, Norwood, Massachusetts under his personal supervision 




